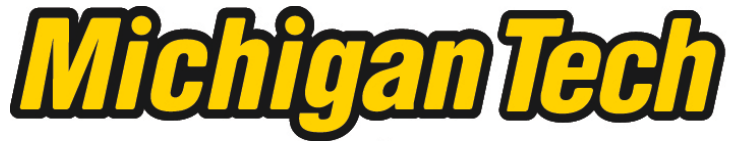 \\ Michigan Technological University Create the Future Digital Commons @ Michigan Tech
}

Dissertations, Master's Theses and Master's Reports - Open

Dissertations, Master's Theses and Master's

Reports

2011

\section{Tracing the source of groundwater for three different coastal peatlands along Lake Superior}

Margus Paesalu

Michigan Technological University

Follow this and additional works at: https://digitalcommons.mtu.edu/etds

Part of the Forest Sciences Commons

Copyright 2011 Margus Paesalu

\section{Recommended Citation}

Paesalu, Margus, "Tracing the source of groundwater for three different coastal peatlands along Lake Superior", Master's Thesis, Michigan Technological University, 2011.

https://doi.org/10.37099/mtu.dc.etds/149

Follow this and additional works at: https://digitalcommons.mtu.edu/etds

8 Part of the Forest Sciences Commons 
TRACING THE SOURCE OF GROUNDWATER FOR THREE DIFFERENT COASTAL PEATLANDS ALONG LAKE SUPERIOR

\author{
By \\ MARGUS PAESALU
}

\begin{abstract}
A THESIS
Submitted in partial fulfillment of the requirements for the degree of MASTER OF SCIENCE

Forest Ecology and Management
\end{abstract}

MICHIGAN TECHNOLOGICAL UNIVERSITY

2011

(C) Margus Paesalu 2011 
This thesis, "Tracing the Source of Groundwater for Three Different Coastal Peatlands along Lake Superior," is hereby approved in partial fulfillment of the requirements for the Degree of MASTER OF SCIENCE IN FOREST ECOLOGY AND MANAGEMENT.

School of Forest Resources and Environmental Science

Signatures:

Thesis Advisor

Dr. Thomas Grant Pypker

Thesis Co-advisor

Dr. Eric Agestam

Committee Member

Dr. Rodney A. Chimner

Committee Member

Dr. John S. Gierke

Dean

Dr. Margaret R. Gale

Date 


\section{Table of Contents}

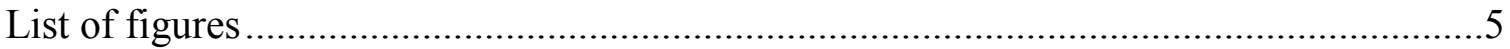

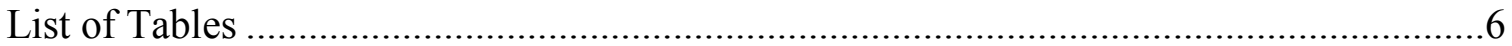

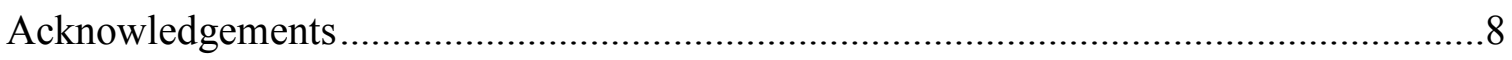

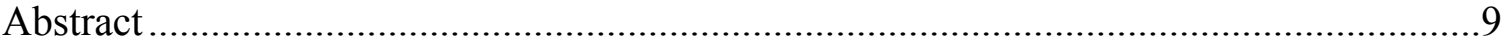

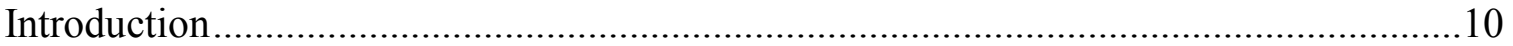

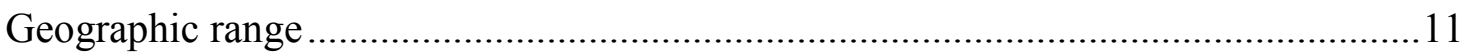

The importance of wetlands and their functions........................................................ 11

Global carbon cycle ………………….........................................................11

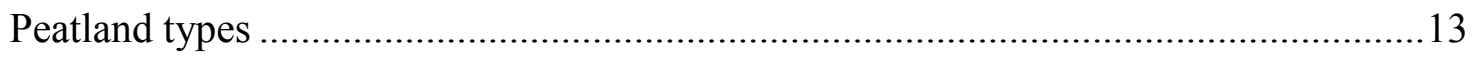

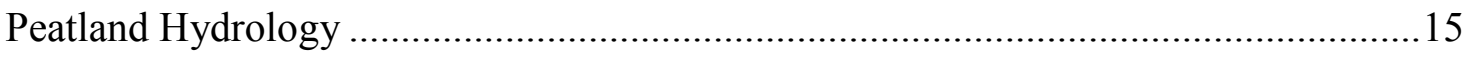

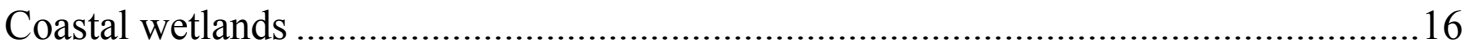

Coastal Great Lakes peatlands .............................................................................

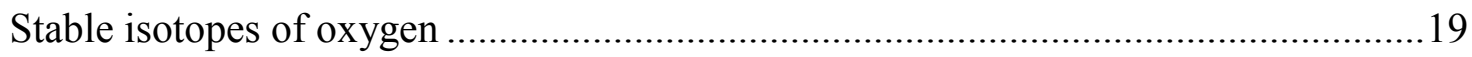

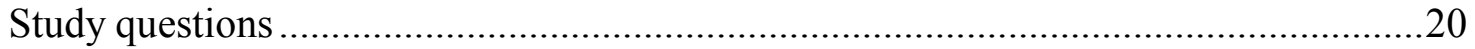

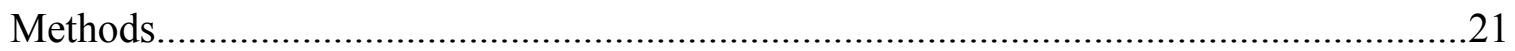

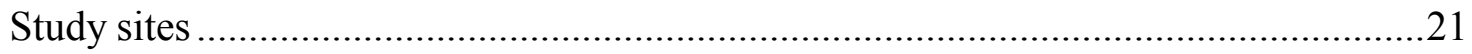

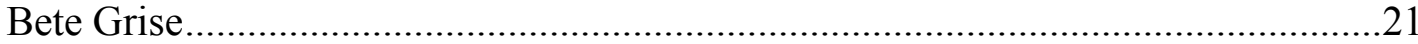

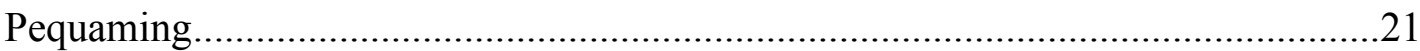

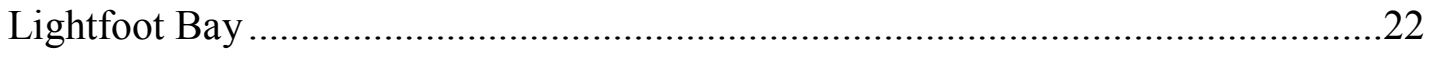

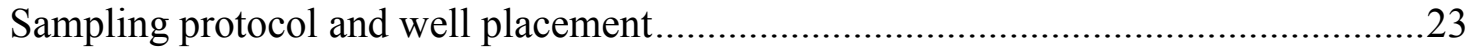

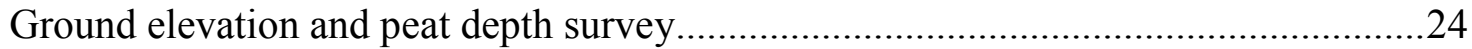

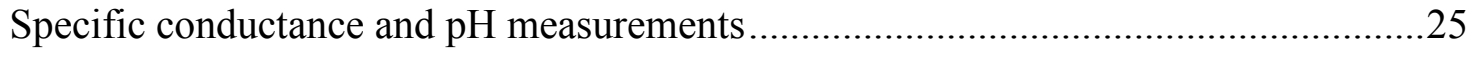

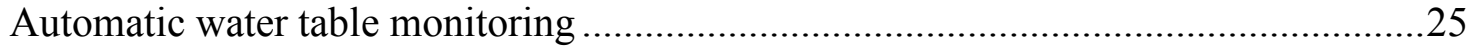

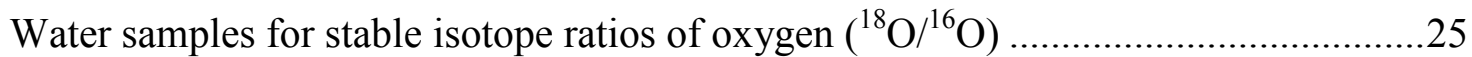

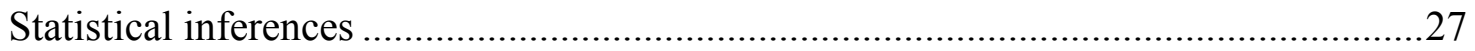

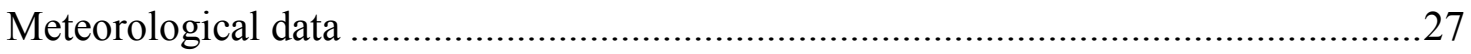

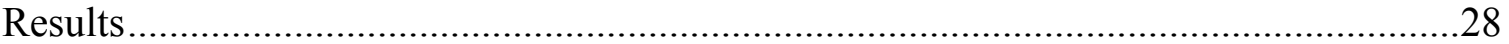


Weather conditions and the water table height ..................................................28

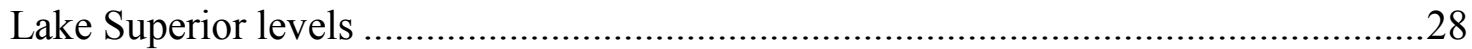

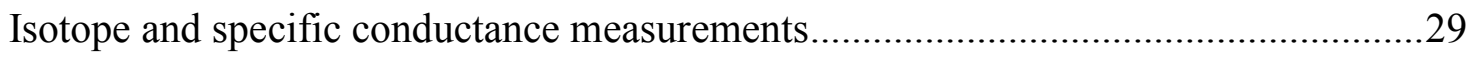

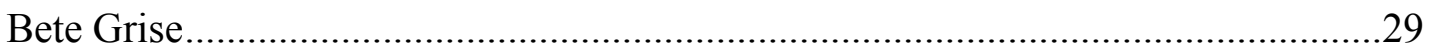

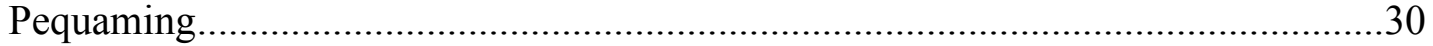

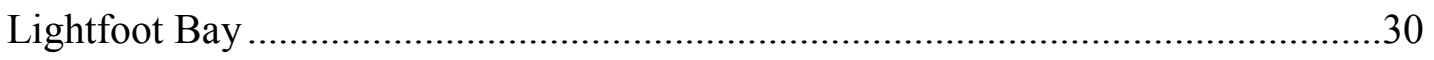

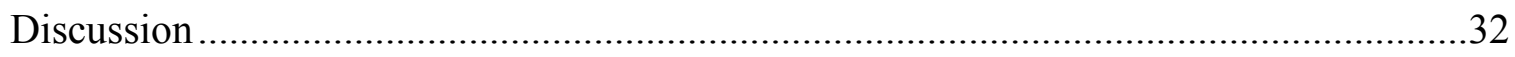

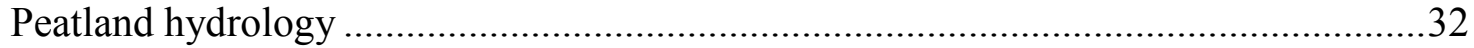

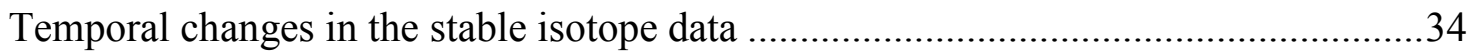

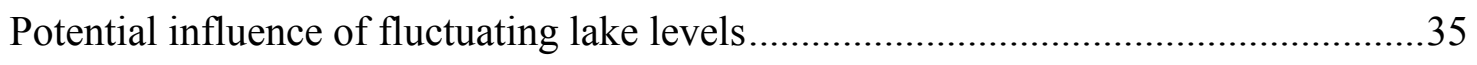

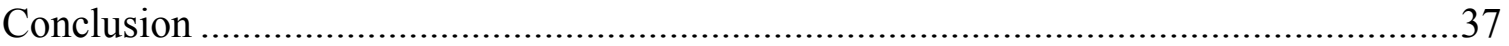

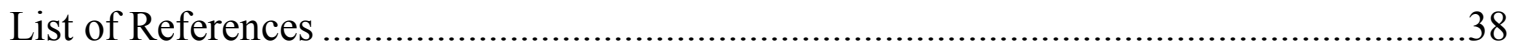

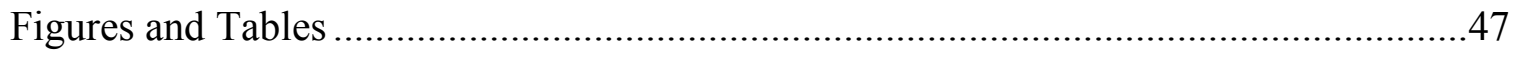

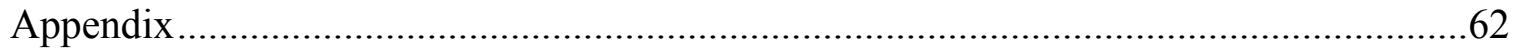




\section{List of figures}

Figure 1. Study sites in the vicinity of the Keweenaw Peninsula in Upper Michigan of the United States. .47

Figure 2. Transect of installed wells at Bete Grise 48

Figure 3. Transect of ground water monitoring wells at the tombolo peatland, Pequaming. The star marks the position of the permanent study site with the water table logger.

Figure 4. Transect of ground water monitoring wells at Lightfoot Bay peatland complex .50

Figure 5. Cross section of probed peat depths of Bete Grise dune and swale complex ....51

Figure 6. Cross section of probed peat depths of the Pequaming peatland complex.........52

Figure 7. Cross section of probed peat depths of Lightfoot Bay peatland complex ..........53

Figure 8. Houghton County mean daily air temperatures and monthly accumulated precipitation, Jan 2010 to Dec 2010. Long term mean temperature data dates from 1889 to 2009. .54

Figure 9. Lake Superior monthly levels of 2010, average monthly levels from 1918 to 2009, and annual average level .55

Figure 10. Water table height and precipitation at Pequaming. .56

Figure 11: Specific conductance at all sites (A) Pequaming, (B) Lightfoot Bay, (C) Bete Grise

Figure 12. Delta ${ }^{18} \mathrm{O} /{ }^{16} \mathrm{O}$ isotope ratios showing the amount of ground water supporting each site. Note that Pequaming (PQ) is missing the third sampling date due to potential sampling error from surface water

Figure 13: Layout of the 0.1 ha circular vegetation survey plots. The circle was divided into four quarters according to cardinal directions. $3 \times 3 \mathrm{~m}$ plots were used for shrub layer sampling and $1 \times 1 \mathrm{~m}$ plots for the herbaceous layer, all placed randomly within the quarters.

Figure 14. Monthly air and groundwater temperatures at Pequaming. .62 


\section{List of Tables}

Table $1 .{ }^{18} \mathrm{O}$ stable oxygen isotope ratios of all sites with $95 \%$ confidence intervals ......60

Table 2. Student's pairwise comparison of ${ }^{18} \mathrm{O}$ isotope ratios between vegetation zones and lake water

Table 3. One-way ANOVA of specific conductance for each vegetation zone compared to lake water .61

Table 4. Seasonal summary table of specific conductance $(\mu \mathrm{S} / \mathrm{cm})$ at Pequaming. .63

Table 5. Seasonal summary table of specific conductance $(\mu \mathrm{S} / \mathrm{cm})$ at Lightfoot Bay .....63

Table 6. Seasonal summary table of specific conductance $(\mu \mathrm{S} / \mathrm{cm})$ at Bete Grise..........64

Table 7. Seasonal summary table of $\mathrm{pH}$ at Pequaming .64

Table 8. Seasonal summary table of $\mathrm{pH}$ at Lightfoot Bay .65

Table 9. Seasonal summary table of $\mathrm{pH}$ at Bete Grise .65

Table 10. Mean daily temperatures and monthly accumulated precipitation from 1889 to 2009 and for 2010

Table 11. Lake Superior levels of 2010 and long-term recorded monthly minimum and maximum levels at Marquette, MI.

Table 12. Pooled seasonal average specific conductance with respect to distance from upland at Lightfoot Bay and Pequaming 68

Table 13. Air and groundwater temperatures at Pequaming .68

Table 14. Ground elevation and peat depth survey, Lightfoot Bay .69

Table 15. Ground elevation and peat depth survey, Pequaming. .70

Table 16. Ground elevation and peat depth survey, Bete Grise. .71

Table 17. Specific conductance (SE) all season Pequaming open fen ...........................71

Table 18. Specific conductance (SE) all season Pequaming transition zone....................72

Table 19. Specific conductance (SE) all season Pequaming upland and lake water ........72

Table 20. Specific conductance (SE) all season Lightfoot Bay open fen ........................73

Table 21. Specific conductance (SE) all season Lightfoot Bay transition zone ...............73

Table 22. Specific conductance (SE) all season Lightfoot Bay upland ...........................74 
Table 23. Specific conductance (SE) all season Bete Grise upland

Table 24. Specific conductance (SE) all season Bete Grise dune and swale complex .....75

Table 25. Vegetation survey Bete Grise upland …................................................... 76

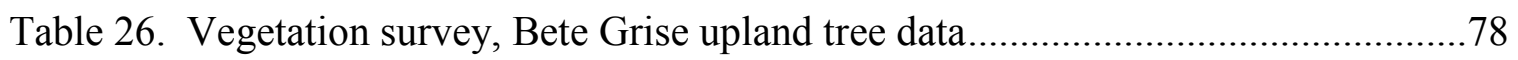

Table 27. Vegetation survey Bete Grise swale ............................................................ 79

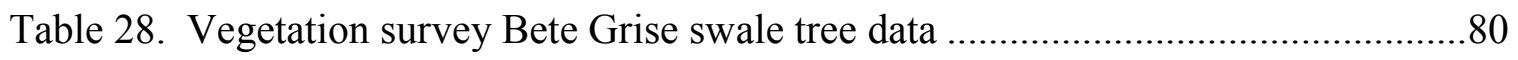

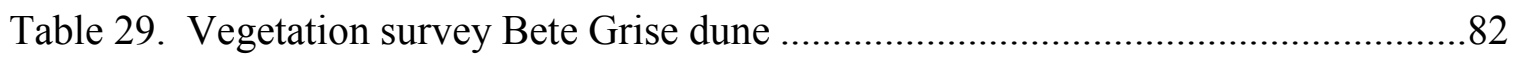

Table 30. Vegetation survey Bete Grise dune tree data............................................83

Table 31. Vegetation survey Pequaming open fen ................................................. 85

Table 32. Vegetation survey Pequaming open fen tree data.......................................86

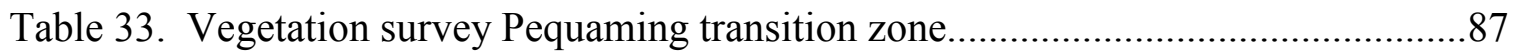

Table 34. Vegetation survey Pequaming transition zone tree data................................88

Table 35. Vegetation survey Pequaming upland ..................................................... 89

Table 36. Vegetation survey Pequaming upland tree data...........................................90

Table 37. Vegetation survey Lightfoot Bay open fen..............................................92

Table 38. Vegetation survey Lightfoot Bay transition zone .......................................93

Table 39. Vegetation survey Lightfoot Bay transition zone tree data ...........................94

Table 40. Vegetation survey Lightfoot Bay upland ................................................96

Table 41. Vegetation survey Lightfoot Bay upland tree data ....................................97 


\section{Acknowledgements}

First and foremost, I'd like to thank my advisor Thomas Pypker for always being there when I needed encouraging or directions throughout the project, his inspiriting instruction and professional demeanor has been invaluable. I owe a special thanks to Rodney Chimner for constructive suggestions and a positive attitude towards my work, which was both helpful and motivating. I'd like to thank John Gierke and Eric Agestam for being in my committee and I'm grateful to Tord Magnusson for providing helpful advice towards the end of the thesis writing in this collaborative dual degree program involving Michigan Technological University and Swedish University of Agricultural Sciences.

A word of gratitude goes out to the aidant fellow students of the School of Forest Resources and Environmental Science. John Hribljan and Laura Kangas provided critically important tips for starting the project, as well as know-how on to use the laboratory equipment. Tamara Baker was of great help conducting the vegetation survey, Stephen Curelli came out with me to the field sites in early November snow to carry out the high resolution GPS landscape and peat depth survey. I owe a spcial thanks to Anna Hess, who helped me compile site maps at the last minute.

This project was partially funded by the Michigan Technological University's Ecosystem Science Center. I am thankful to Michael Hyslop, Ann Maclean and Eugene Levin for providing tips on precise GIS surveying on a landscape. I would also like to express my gratitude to Jennifer Eikenberry, who assisted with laboratory work.

On a personal note, I'd like to thank Christopher Johnson, Kassidy Yatso, James Bess, Arvo Aljaste, Alex Collins, Scott Robinson and many other students of the SFRES that have been helpful in providing advice, as well as being amicable and supportive in everything that I undertook during my graduate studies in Michigan. The friends made along the way and the experience gained has made it a very special time in my life. I want to thank you all for this! 


\section{Abstract}

The goal of this project was to investigate the influence of a large inland lake on adjacent coastal freshwater peatlands. The specific aim was to determine the source of groundwater for three differently formed peatlands located on the southern shore of Lake Superior. The groundwater study was conducted at Bete Grise, a peatland complex in a dune-swale system; Pequaming, a peatland developed in the swale of a tombolo; and Lightfoot Bay, a peatland developed in a barrier beach wetland complex.

To determine the source of groundwater in the peatlands, transects of six groundwater monitoring wells were established at each study site, covering distinctly different vegetation zones. At Pequaming and Lightfoot Bay the transects monitored two vegetation zones: transition zone from upland and open fen. At Bete Grise, the transects monitored dunes and swales. Additionally, at all three sites, upland groundwater was monitored using three wells that were installed into the adjacent upland forest. Biweekly measurements of well water $\mathrm{pH}$ and specific conductance were carried out from May to October of 2010. At each site, vegetation cover, peat depths and surface elevations were determined and compared to Lake Superior water levels. From June 14 - 17, July 20 - 21 and September $10-12$, stable isotopes of oxygen $\left({ }^{18} \mathrm{O} /{ }^{16} \mathrm{O}\right)$ ratios were measured in all the wells and for Lake Superior water. A mixing model was used to estimate the percentage of lake water influencing each site based on the oxygen isotope ratios.

During the sampling period, groundwater at all three sites was supported primarily by upland groundwater. Pequaming was approximately $80 \%$ upland groundwater supported and up to $20 \%$ Lake water supported in the uppermost $1 \mathrm{~m}$ layer of peat column of the transition zone and open fen. Bete Grise and Lightfoot Bay were $100 \%$ upland groundwater supported throughout the season. The height of Lake Superior was near typical levels in 2010. In years when the lake level is higher, Lake water could intrude into the adjacent peatlands. However, under typical hydrologic conditions, these coastal peatlands are primarily supported by upland groundwater. 


\section{Introduction}

Peatlands are terrestrially occurring wetlands where ecosystem respiration rates are lower than the net primary production, thus creating favorable conditions for organic soil accumulation in the form of peat (Wieder and Vitt 2006). The anoxic environment caused by waterlogged conditions is the most important factor contributing to this unique habitat. Different criteria apply for the classification schemes, but the most common being organic soil depth of greater than 30 or $40 \mathrm{~cm}$ (Gorham 1991).

Peatland development is the result of terrestrialization, paludification or primary peat formation. Terrestrialization is the slow process of peat development in open bodies of stagnant water, gradually closing in from the edges with a floating mat of vegetation. Paludification is the most common form of peat formation, a process also known as swamping. In this process, peat accumulation begins directly over previous drier mineral soil. Primary peat production is a process described by peat formation directly on bare wet mineral soil, creation of which favored by the glacial retreat and the resulting land rise owing to the isostatic rebound (Wieder and Vitt 2006).

Peat accumulation speeds vary greatly depending on the decomposition (mineralization) rate, which is mainly driven by water saturation and ambient temperature, as well as aerobic or anaerobic conditions (Moore and Dalva 1993; Yavitt et al. 1997; Glatzel et al. 2004). In Ecuador, for example, Chimner and Karberg (2008) have determined the accumulation rate of $1.3 \mathrm{~mm} \mathrm{year}^{-1}$. Several studies show the average height accumulation of $0.6 \mathrm{~mm}$ year $^{-1}$ for Northern Europe (Aaby 1986) and 0.6 - $0.8 \mathrm{~mm}$ year ${ }^{-1}$ for boreal areas of the Russian Federation (Botch and Masing 1983). Gorham and others (unpublished) have estimated the overall average peat accumulation of $0.48 \mathrm{~mm}$ year $^{-1}$ for Canada. 


\section{Geographic range}

Peatlands are found in every ecoregion of the world, from arctic to tropical climates, (Gore 1983; Immirzi et al. 1992; Gignac and Vitt 1994; Lappalainen 1996; Charman 2002). Wetlands (marshes, mires, swamps and peatlands) cover about or between 4 to $6 \%$, or $4 \times 10^{6} \mathrm{~km}^{2}$ of land area on Earth in total (Mitch and Gosselink 2000 , Rosa 2008). Nearly $93 \%$ of them are found in six predominantly boreal countries (Gorham 1991, Mitsch and Gosselink 2000, Joosten and Clarke 2002, Wieder and Vitt 2006). The largest intact area of peatlands in the world is on the vast West Siberian Plain in the Russian Federation (Neishtadt 1977, Walter 1977, Neustadt 1984, Gorham 1991). The second largest area is the Hudson Bay Lowland of Canada (Gorham 1991).

The majority of peatlands are located in the boreal zone due to several factors, the most important of which being the positive water balance in the region during all or part of the growing season. The positive water balance allows local water tables to stabilize (Wieder and Vitt 2006).

\section{The importance of wetlands and their functions}

\section{Global carbon cycle}

Peatlands are an important sink of carbon. $\mathrm{CO}_{2}$ fixed by plants, subsequently is deposited as dead plant material (Wieder and Vitt 2006). The fixation of carbon by plants is counterbalanced by the release of carbon via plant and soil respiration, the loss of dissolved organic carbon (DOC) through the groundwater and the release of $\mathrm{CH}_{4}$ because of methanogenesis (Wieder and Vitt 2006). The high water tables in peatlands create anaerobic conditions that prevent the decay of the dead plants, thereby causing the peatland to be a carbon sink. The ratio of net primary production (NPP) and peat accumulation is estimated to be between 1 to $20 \%$ (Tolonen 1979; Tolonen et al. 1992; Warner et al. 1993; Francez and Vasander 1995; Moore et al. 2002; Feng 2002, Wieder and Vitt 2006). Therefore, peatlands act as an important reservoir of carbon storage. 
More than $1 / 3$, or 455 petagrams ( $455 \times 10^{15}$ grams), of the world's soil carbon is stored in the organic soils of peatlands (Gorham 1991), while occupying only $3-4 \%$ of global land area (Mitsch and Gosselink 2000). The carbon stored in these peatlands has been estimated to range between $50-150 \mathrm{~kg} \mathrm{C} \mathrm{m}^{-2}$ and the accumulation rates are estimated to range between 10 and $30 \mathrm{~g} \mathrm{C} \mathrm{m}^{-2} \mathrm{y}^{-1}$ (Gorham 1991; Turunen et al. 2001, Wieder and Vitt 2006).

The large carbon stores may have several adverse effects on the global emissions to the atmosphere. For example, single large scale fire events can release vast quantities of carbon through peat combustion thereby altering the global atmospheric carbon balance. Page et al. (2002) estimated that the burning of 730000 ha of tropical peatlands in 1997 released approximately $0.19-0.23$ Gigatonnes $\left(10^{9}\right.$ tons $)$ to the atmosphere. The authors extrapolated the figures to the whole of Indonesia for one season of peat fires and concluded that between $0.81-2.57 \mathrm{Gt}$ of carbon was released. Hence, peat fires in Indonesia represented one tenth to two fifths of the $6.4 \mathrm{Gt}$ of carbon released globally by fossil fuels in 1957 (Page et al. 2002).

In the light of increasing global temperatures of the atmosphere, peatlands that have been regarded as net carbon sinks are now being studied in great detail with regards to becoming potential net producers of carbon into the atmosphere. The shift of temperatures is expected to be most significant in boreal zone (Houghton et al. 1992), where summers will likely have higher temperatures and, thus, along with the drawdown of the water table, the mineralization or decomposition of peat could occur at a higher speed.

Peatlands not only store carbon dioxide, but also produce two other greenhouse gases, $\mathrm{CH}_{4}$ and nitrous oxide. According to Bartlett and Harriss (1993), peatlands contribute up to $9 \%$ of the Earth's $\mathrm{CH}_{4}$ from natural sources due to anoxic conditions often found in peatlands. $\mathrm{CH}_{4}$ is 23 times better at absorbing ultraviolet radiation than carbon dioxide, but has a much shorter atmospheric residence time (14.4 years compared to 230 years of $\mathrm{CO}_{2}$ ) (Gorham 1991, Meehl et al. 2007, Watterson 2008). $\mathrm{CH}_{4}$ is 
produced by the splitting of acetate, which comes from the fermentation of organic matter (Kelley et al.1992).

The answer to whether one third of world's sequestered soil carbon will affect the climate as the temperatures rise is yet unclear. Complex processes within peatlands vegetation dynamics, water table fluctuations, biochemical processes within the peat and other factors have high variability, hence each eco-zone has to be studied independently and no broad conclusions have yet been made. Large biotic feedbacks are expected to occur in northern wetlands, as the global temperatures rise (Houghton et al. 1992). A comprehensive study conducted by Bridgham et al. (1998) of carbon, nitrogen and phosphorus mineralization rates in northern peatlands concluded that carbon mineralization rates were relatively constant over different sites, while methane production varied greatly. The authors suggested that the respiratory response of the soil to changes in climatic patterns will likely be very different for these two important greenhouse gases (Bridgham et al. 1996).

\section{Peatland types}

Peatlands are directly dependent on a long term water supply that is relatively constant, while the origin of the water determines the form and function of the peatland (Rydin and Jeglum 2006). Ground water and precipitation are the two main sources of water. Water and nutrient availability for the peatland flora is influenced by seasonal precipitation patterns and the height of the groundwater table. Seasonal variations in hydrology force the vegetation to adapt to constantly changing environments. Specific propagation strategies and differences in nutrients absorption have developed over time in many of the plant species that are found in these ecosystems. For example, carnivorous plants like sundew (Drosera spp) and pitcher plant (Sarracenia spp) have adapted to catch and digest bugs using enzymes to compensate for the lack of nutrients of the habitat (Bridgham et al. 1998). 
Northern peatlands are structured into two broad categories - fens and bogs. The two main peatland types are delineated based on the physiochemical properties of the groundwater supporting them. Fens have inputs of groundwater or surface runoff enriched in bases and nutrients, that originate from surrounding uplands and thus are termed minerotrophic fens. Fens can be further divided into rich and poor. Rich fens have greater quantities of nutrients in the ground water, mostly calcium, relative to poor fens, which are more nutrient limited. There is no uniform set limit for $\mathrm{pH}$ that can help classify fens only by their surface water $\mathrm{pH}$, but according to Malmer (1986) poor and rich fens can differentiated by the acidity-alkalinity gradient of $\mathrm{pH} 5.5$ in northwestern Europe. In contrast to fens, bogs are termed ombrotophic, which is explained by the domed shape above the surrounding landscape which disconnects them from the groundwater supply, and thus bogs rely on atmospheric inputs of nutrients and bases to the peat surface (Gorham 1991, Bridgham et al.1998). As a result, bogs are more acidic, with the $\mathrm{pH}$ of the surface water ranging approximately from 3.5 to 4.5 (Malmer et al.1992). Bog surface waters have low $\mathrm{pH}$, because of the water input from the atmosphere lacks the alkalinity to neutralize the strong acids that are released from decomposing peat (Hemond 1980; Gorham et al. 1985; Reeve 1996; Glaser et al. 2004; Siegel et al. 2006). The difference in available nutrients affects the vegetation communities.

Vegetation of the boreal peatlands ground layer was first classified according to the rich or poor fen gradient by DuReitz (1954). Wieder and Vitt (2006) described the minerotrophic, acidophilous Sphagnum-dominated plant communities with rather low species diversity were termed as poor fens, while species with high fidelity for nearly neutral soil $\mathrm{pH}$ or calcareous conditions were found in rich fens. Rich fens usually do not have a significant cover of Sphagnum peat mosses, rather they have a number of true mosses. Sphagnum mosses dominate only in precipitation fed bogs and precipitation and groundwater fed poor fens, however, this rule does not always apply, since Sphagnum mosses are also found in some rich fens. The type of the ground covering layer retains a 
critical difference for classification between bogs and poor fens, as several authors have suggested (Gorham and Janssens 1992; Vitt 2000; Wheeler and Proctor 2002).

\section{Peatland Hydrology}

Peatland formation and function is determined by the origin of the constant, longterm water supply. The link between peatland biota and hydrology has been known for more than a century. Dau (1823) was one of the first scientists to recognize and document three types of peatlands, according to the origin of water. Weber (1902) developed the concept of a raised bog, which is fed only by atmospheric precipitation. The movement of water in peatlands with the water table height fluctuations influences plant growth, resulting in the distinct vegetation patterns of hummocks, hollows, and pools (Gorham 1953; Iversen 1973; Sjörs 1963, Siegel and Glaser 2006).

Groundwater is defined as "subsurface water that flows through any saturated porous media regardless of its composition (mineral or organic), degree of consolidation (rock or sediment), or location (terrestrial or marine)" (Siegel and Glaser 2006). The rate of groundwater flow is determined by the physical properties of the porous media. Not all pores are connected and, thus, groundwater movement is limited to the connected pores, which is termed as effective porosity (connected pores which are $0.5 \mathrm{~mm}$ or greater).

Siegel and Glaser (2006) have summarized the basic principles of groundwater hydrology regarding petlands:

"Primary porosity develops when a rock or soil is formed. Although the total porosity of any rock or mineral soil is spatially variable, it remains relatively constant over decadal or century time scales. In contrast, the effective porosity of peat continually changes both spatially and temporally because of biological processes. Microbial decomposition, for example, continually breaks down the solid-phase peat skeleton, reducing the size of the pores and increasing the bulk 
density of the peat. As the pores become smaller the capillary tension between the pore waters and peat walls increases exponentially, thereby restricting the movement of water under the force of gravity or pressure." Additionally, it is of crucial importance to consider the multi-directional factors that affect the flow of groundwater. "The hydraulic conductivity of all porous media usually changes with direction. In the event of no formation of secondary porosity, hydraulic conductivity will decline exponentially with depth as various biological and physical processes reduce the volume of interconnected pore space" (Siegel and Glaser 2006).

Different peats have different hydraulic properties, for example a 100 to a 1000 fold discrepancy can occur in the hydraulic conductivity of well-humified Sphagnum peat $\left(10^{-6} \mathrm{~cm} \mathrm{~s}^{-1}\right)$ compared to fibric sedge peat $\left(10^{-4} \mathrm{~cm} \mathrm{~s}^{-1}\right)$ (Podniesinski and Leopold 1998). Such variation can draw a difference in the ground water flow paths through the site.

Ingram (1978) proposed the concept of the uppermost surface layer of acrotelm, consisting of poorly to well decomposed organic material, where water levels fluctuate throughout the year, and underneath, the permanently saturated zone made of well decomposed peat - the catotelm (Rosa 2008). Hydraulic conductivity is higher near surface of the acrotelm, while it is much lower in the catotelm (Ingram 1978, Fraser et al 2001, Drexler et al 1999). However, the acrotelm-catotelm concept has been considered ambiguous, because it is vaguely described and mostly site dependent (Amon et al. 2002).

\section{Coastal wetlands}

Coastal wetlands usually lie in the bordering and transition of terrestrial ecosystem zone into aquatic ecosystem and thus, are directly affected by both. Several categories of coastal wetlands occur, some of which border the oceans while others occur in freshwater systems. 


\section{Coastal Great Lakes peatlands}

The Great Lakes region of the United States was shaped by glaciation. The lake levels have shifted by tens of meters as the geological processes evolved in post-glacial periods as the ice retreated, and have been more stable and at levels as we know them today for less than 5000 years (Herdendorf 1992, Booth et al. 2002). Four types of stream and shoreline processes provided favorable sites for wetlands as the lakes became established: (1) delta formation, (2) estuary formation, (3) sandbar and dune formation creating coastal lagoons, and (4) solution lagoons (Herdendorf 1992).

The coastal wetlands in the Great Lakes region today hold a diversity of functions which are a mix of ecological and social uses can be categorized as (1) wetlands as habitats (fish production, spawning and nursery; waterfowl migration, wintering, and nesting; invertebrate and mammal habitat), (2) economical values (agricultural use, peat, blueberries, wild rice, etc.; commercial and sport fishing; waterfowl hunting; nonconsumptive recreation (bird watching, canoeing, hiking, etc.)), (3) physical functions of wetlands (groundwater recharge and flood storage; sedimentation basins; pollution control (waste assimilation, toxic substance absorption, nutrient uptake, etc.; coastal protection (attenuate wave attack) (adopted from Herdendorf 1992, Jaworski et al. 1978).

Coastal peatlands are a specific type of peatlands that have been formed by the combination of high energy waves occurring at the shoreline, the fluctuations of the water level and the land forms created by the retreat of the Pleistocene ice sheets (Herdendorf 1992). These factors contribute to sediment build-up over time, resulting in a variety of differently formed and functioning wetlands. For example, in peatlands of the northern Great Lakes region, trees are often stunted in growth, or do not appear at all, due to saturated growing conditions of the open fen or the seasonally dry conditions of an ombrotrophic bog. In some instances trees can thrive in mineral rich fens, often forming cedar swamps. Albert et al. (2005) developed a classification scheme for Great Lakes coastal wetlands, based on their specific hydrological and geomorphological conditions. According to their hydrogeomorphic (HGM) model, three main types of wetlands - 
lacustrine system, riverine system and barrier-enclosed systems occur in the Great Lakes Region.

Lacustrine, riverine and barrier-enclosed wetlands form under different conditions. Lacustrine systems are exposed, having little or no protection from the nearshore processes such as seiches, lake-level fluctuations, near-shore currents and ice scour of the lake, thus restricting vegetation development. Riverine systems occur along and within rivers, but are less affected by coastal processes. Barrier-protected systems are formed by either coastal or fluvial processes, but are separated from the lake by a barrier feature, often a barrier beach. The isolation from lake creates a suitable environment for wetland initiation, which usually occur in the swales behind the sand barrier. If several sand ridges parallel to the shoreline have formed over the course of the time, a distinguished form of wetlands emerge in the swales between the dunes - thus called the ridge and swale or dune and swale complexes. These usually occur in embayments, where enough supply of sediment is available. In the upper Great Lakes region alone, more than 100 of these complexes have been determined (Cromer and Albert 1991, Cromer and Albert 1993, Baedke et al. 2004).

Additionally, if an island is attached to the mainland by barrier beaches, a deposition landform called tombolo emerges (Hsu and Silvester 1990). The sediment accretion, also known as a salient, is developed by waves diffracting around the offshore barrier (an island), thereby slowing down and depositing sediment along the centerline, over time connecting the offshore barrier to the mainland. The resulting barrier enclosed system within a tombolo with more isolated and stable hydrologic conditions usually sustains a suitable environment for a wetland in the swale of a tombolo (Albert et al. 2005). 


\section{Stable isotopes of oxygen}

Stable isotopes have emerged during the recent decades in ecological studies, providing previously unavailable opportunities to utilize them as geochemical tracers to determine the function or a process within a large frame of different applications (Hoffmann et al. 2000). The isotopes of any given element are characterized by their number of neutrons. Stable isotopes of oxygen ${ }^{16} \mathrm{O},{ }^{17} \mathrm{O}$ and ${ }^{18} \mathrm{O}$ are components of naturally occurring oxygen. The most abundant is ${ }^{16} \mathrm{O}$, comprising for more than $99 \%$ of all oxygen isotopes. The stable isotopes of water molecules of lighter atomic mass are more likely to evaporate and fall as precipitation, thus building up concentrations of heavier isotopes in different hydrologic cycles. Mass spectrometry enables us to quantify the isotope ratio $\left({ }^{16} \mathrm{O} /{ }^{18} \mathrm{O}\right)$ or the relationship between atomic number and mass of a given example of water and express the values in an internationally recognized standard. For water samples, the VSMOW or Vienna Standard Mean Ocean Water scale is often used (Hoffmann et al. 2000).

Stable isotopes can applied to a broad scale of hydrologic questions. Past research have used stable isotopes to determine the source of water used by plants (e.g. Dawson and Ehleringer, 1991; Dawson, 1993). For example, Chimner and Cooper (2004) studied a site in Colorado to determine the water source for native shrubs in San Luis Valley. The root system of the endemic shrubs is adapted to different water table heights, changing their water uptake source according to the seasonal monsoon rains. Additionally, the movement of water can be traced. For example, Ronkanen et al. (2007) determined the flow patterns of water in a constructed wetland treating municipal wastewater in Finland. The isotope study helped to determine both active flow volume and preferential pathways, which turned out to be in the top $40 \mathrm{~cm}$ layer in the peatland. A study of this type helped to determine the area-efficiency of the wastewater treatment and potential improvements. Lastly, Wilcox et al. (2004) quantified the flows of groundwater using isotopes in the North-East Everglades in Florida to determine whether groundwater pumping for human use affected the aquifer underlying the Everglades. Isotopic analysis helped them determine that up to $60 \%$ of water beneath the Everglades was removed by 
pumping water for municipal use. Hence, environmental isotopes can be used in a variety of ways to better understand the hydrology of peatlands.

\section{Study questions}

The hydrologic conditions of each of the coastal wetland type in the Great Lakes region have been characterized only in general terms by Albert et al. 2005, but the influence of lake water to these differently formed peatlands has not been partitioned. This project uses stable isotopes to determine the source of groundwater for three barrierenclosed coastal freshwater systems in Lake Superior. The three peatlands are described as a dune and swale complex, a barrier beach lagoon and a tombolo.

The hypotheses of this study were: (1) groundwater dominates the dune and swale complex and the barrier beach lagoon peatland, (2) while the more exposed tombolo at Pequaming is supplied primarily by lake water. 


\section{Methods}

\section{Study sites}

The study occurred in three coastal peatlands, Bete Grise, Pequaming and Lightfoot Bay that are located in the Upper Peninsula of Michigan, United States (Figure 1). All three peatlands are located on the southern shore of Lake Superior and were formed under its geomorphic conditions (Boisvert 2009). The bedrock in all study sites is mostly Jacobsville sandstone of Precambrian origin (Doonan and Byerlay 1973).

\section{Bete Grise}

Bete Grise is a dune and swale wetland complex (latitude 47²1'53.51" N longitude 8757'56.15" W, Figure 2). The dunes primarily support conifers (e.g. balsam fir (Abies balsamea), paper birch (Betula papyrifera), black spruce (Picea mariana) and northen white cedar (Thuja occidentalis) and swales supporting poor fen communities (Boisvert 2009). The poor fen consists primarily of bryophytes (Sphagnum spp), three-seeded sedge (Carex trisperma), labrador tea (Ledum groenlandicum), tag alder (Alnus incana), willows (Salix spp), black spruce (Picea mariana) and tamarack (Larix laricina). Boisvert (2009) determined that at Bete Grise the basal zone of the shallow peat layer consisted of very humic, granular peat, which had a poorly humic Sphagum peat atop.

\section{Pequaming}

Pequaming is a wetland complex formed in the swale of a tombolo (latitude $46^{\circ} 51^{\prime} 9.72^{\prime \prime}$ $\mathrm{N}$ longitude $88^{\circ} 22^{\prime} 35.41^{\prime \prime} \mathrm{W}$, Figure 3), consisting of a large expanse of island mixed mire (Rydin and Jeglum 2006) with large expanses of floating sedge and Sphagnum mat interspersed with small bog-like treed islands (Boisvert 2009). Boisvert (2009) showed that the basal zone of peat consisted of very humic peat, with partly humic peat with traces of Sphagnum moss atop, the uppermost zone poorly decomposed peat of Carex ssp and Sphagnum ssp. The transition zone from upland into open fen at Pequaming is a thick 
cedar swamp with distinct microtopography of hummocks covered mainly by northern white cedar (Thuja occidentalis), tag alder (Alnus incana), bryophytes (Sphagnum spp), horsetail (Equisetum spp), labrador tea (Ledum groenlandicum), royal fern (Osmunda regalis) and bluejoint (Calamagrostis canadensis). The open fen has sparsely spaced tree islands populated by stunted tamarack and northern white cedar and that were less than 2 $\mathrm{m}$ in height. Both the hummocks and lawns were covered by bryophytes (Sphagnum spp), bog-rosemary (Andromeda polifolia), bog golden rod (Solidago uliginosa), pitcher plant (Sarracenia purpurea), horsetail (Equisetum spp), wiresedge (Carex lasiocarpa), royal fern (Osmunda regalis), northern white cedar and sweetgale (Myrica gale).

\section{Lightfoot Bay}

Lightfoot Bay is a barrier beach peatland, with a sand ridge separating the wetland from the lake (latitude $46^{\circ} 54^{\prime} 6.47^{\prime \prime} \mathrm{N}$ longitude $88^{\circ} 10^{\prime} 42.81^{\prime \prime} \mathrm{W}$, Figure 4). The peat cores have fine granular peat, likely a gyttja, in the basal zone, partly humic sedge remains in the second zone, poorly decomposed brown moss in the third zone and near-surface zone consisted mainly of poorly decomposed Sphagnum, roots of Carex ssp and leatherleaf (Boisvert 2009). The upland at Lightfoot Bay supports mixed forest of trees. The upland transitions to a treed wetland that has sparse tamarack, northern white cedar and black spruce underlain by bryophytes (Sphagnum spp), small cranberry (Vaccinium oxycoccus), royal fern (Osmunda regalis) sweet gale and leatherleaf (Chamaedaphne calyculata). In the center of the wetland and open floating mat section contains only sparse clumps of northern white cedar seedlings. The herbaceous layer is dominated by bryophytes (Sphagnum spp) and narrow-panicle rush (Juncus brevicaudatus) with quite densely distributed pitcher plant (Sarracenia purpurea). 


\section{Sampling protocol and well placement}

For sampling purposes, we divided the sites into distinctly differing vegetation zones at each of the peatlands. At each of the three peatlands six wells were installed along a transect. In addition to the wells located in the peatland, three wells were installed in the adjacent upland forest (Figures $2-4$ ). All wells inserted into the peatlands were made of $150 \mathrm{~cm}$ long, $5.08 \mathrm{~cm}$ (2") outer diameter polyvinyl chloride pipe. The upland wells were $3.175 \mathrm{~cm}\left(1 \frac{1}{4}\right.$ ”) in diameter and with pointed tips, to make inserting them into handaugered holes as easy as possible. Slits were cut along the bottom 3/5 $(90 \mathrm{~cm})$ of the length of the pipes and covered with geotextile to prevent fine peat matter from seeping into the wells. The tops of the wells were capped to prevent precipitation from directly entering the wells. Due to the different formation patters of the three sites, the wells had to be inserted into different depths to sample ground water throughout the relatively dry summer season. At Pequaming and Lightfoot Bay the wells were inserted approximately $1 \mathrm{~m}$ into the soil, while the existing groundwater monitoring wells and pizeometers (BG4, BG9) reached up to $363 \mathrm{~cm}$ below ground elevation at Bete Grise.

The peatland at Bete Grise has shallow peat that overlays a sandy mineral soil (Figure 5). At Bete Grise we took advantage of an existing network of ground water monitoring wells and piezometers. At Bete Grise, the continuously altering dunes and swales resulted in the locations of wells being evenly spread across the peatland. At Bete Grise, the dune and swale complex (groundwater monitoring wells $4-9$, Figure 2) was pooled as one vegetation zone because of the locations of the wells altering between sand ridges and peat covered swales, while the upland (wells 1,2 and 3) was used a reference for groundwater. At Pequaming and Lightfoot Bay, three wells were inserted in the open fen and three were inserted in a transition zone consisting of tag alder and cedar. 


\section{Ground elevation and peat depth survey}

Trimble ${ }^{\circledR}$ GNSS system

To obtain precise elevation values of the ground water monitoring wells and ground elevations across the sites, a Trimble ${ }^{\circledR}$ Global Navigation Satellite System (GNSS) rover equipped the $\mathrm{R} 8$ receiver with the $\mathrm{TSC} 2^{\mathrm{TM}}$ data controller was used. A temporary reference station, with an additional $\mathrm{R} 8$ receiver, was set up at each field site before beginning the GIS survey to obtain Real Time Kinetic (RTK) GIS data with the highest possible precision. The normalized Root Mean Squared values for elevation precision were $0.255 \mathrm{~m}$ for Lightfoot Bay, $0.011 \mathrm{~m}$ for Pequaming and $0.267 \mathrm{~m}$ for Bete Grise. The WGS84 datum was used as the standard reference. For coordinate calculations between two points in the landscape in order to construct the cross sections of study sites, an online tool available from http://boulter.com/gps/distance/ was used.

To map the peat depths, a 3 meter long, $1 \mathrm{~cm}$ diameter metal probe was used to penetrate through the peat until reaching the underlying mineral soil. Mineral soil was sand for all of the sites and was distinctively harder to push the rod into. Peat depth, ground elevation and GPS coordinates were recorded at each probing location throughout the sampling transect.

The maps of the locations of the groundwater wells were created based on the recorded GPS coordinates using ArcMap ver. 9.3.1. from ESRI Inc., Redlands, California, U.S.A. Aerial photos date from the 2005 National Agricultural Inventory Program (NAIP) and were obtained from the Michigan Geographic Data Library (http://www.mcgi.state.mi.us/mgdl/). 


\section{Specific conductance and $\mathrm{pH}$ measurements}

From 28 May to 27 October 2010, specific conductance was measured on a at least a bi-weekly basis Specific conductance and $\mathrm{pH}$ of each well was measured with handheld $\mathrm{pH}$, conductivity, salinity and temperature system (YSI model 63, YSI incorporated, Yellow Springs, Ohio, U.S.A.). The specific conductance errors are made of instrument accuracy and cell-constant errors, which both account for $.5 \%$ maximum (YSI 63 manual). To measure specific conductance, water samples from the wells were collected by first discharging it with a Jack Rabbit ${ }^{\mathrm{TM}}$ hand pump and then, after 5 to15 minutes, when the groundwater had gradually recharged the well, water was pumped into an open polyvinyl chloride container approximately 4 liters in volume. The container was rinsed thoroughly using distilled water at each well. Lake Superior water was also sampled in a similar manner from the closest beach to the well transect.

\section{Automatic water table monitoring}

The year round water table data was available only for one site of the three. The automatically recorded water table levels were obtained from the permanent study plot located at the northeast corner of the Pequaming complex (Figure 3). Water table height was measured in a well using a level logger (model 3001 Levelogger ${ }^{\circledR}$ Junior, Solinst ${ }^{\circledR}$, Georgtown, Ont. Canada). The water table data was air pressure corrected from the recorded dataset using barologger ( model 3001 Levelogger ${ }^{\circledR}$ Gold, Solinst ${ }^{\circledR}$ ).

\section{Water samples for stable isotope ratios of oxygen $\left({ }^{18} \mathrm{O} /{ }^{16} \mathrm{O}\right)$}

Water samples were collected on 15 June, 7 July and 10 September at Bete Grise, from Pequaming and Lightfoot Bay on 17 June, 21 July and 12 September, using a similar collection method as described for the specific conductance measurements of the 
water in groundwater monitoring wells.

Water samples from groundwater monitoring wells and Lake Superior were stored in Nalgene ${ }^{\circledR}$ scientific $125 \mathrm{ml}$ plastic bottles and kept on ice on the way back to the laboratory where they were frozen until running them in the mass spectrometer. Freezing of the samples was carried out to prevent the potential diffusive fractionation of water isotopes during evaporation (Merlivat and Jouzel 1979). The water samples were analyzed on a ThermoFinnigan Delta ${ }^{\text {plus }}$ Continuous Flow-Stable Isotope Ratio Mass Spectrometer located in Sam Horner Hall of the School of Forest Resources and Environmental Science of Michigan Technological University. Internationally recognized reference water samples were used to calibrate the equipment before running the field specimens. VSMOW (Vienna Standard Mean Ocean Water), SLAP (Standard Light Arctic Precipitation), and GISP (Greenland Ice Sheet Project) certified isotopic standards were run at the beginning of each analysis. Values were reported on the VSMOW scale. The standard deviation of repeated measurements of a laboratory reference water is 0.2 $\%$.

To estimate the amount of ground water present at each vegetation zone of the site a mixing model was used to calculate the percentage from the ${ }^{18} \mathrm{O} /{ }^{16} \mathrm{O}$ results from the mass spectrometry:

$$
\% \text { ground water }=\frac{\text { sample value }- \text { lake water }}{\text {-lake water }+ \text { upland reference }}
$$

This method assumes there are only two end members affecting the isotopic signature of the ${ }^{18} \mathrm{O}$ isotopes in the peatland groundwater. However, this signature will also be affected by evaporation and precipitation water. Therefore, when interpreting the results, this must be considered. 


\section{Statistical inferences}

One-way analysis of variance (ANOVA) tests were run in SigmaPlot (version 11.0 from Systat Software, Inc., Chicago, IL, U.S.A.) to compare the specific conductance values of each vegetation zone at each site against each other and lake water using pairwise multiple comparison procedures (Tukey Test). Additionally, pairwise Ttests for means were run in SigmaPlot to compare the ${ }^{18} \mathrm{O} /{ }^{16} \mathrm{O}$ ratios for each vegetation zone (three pooled sampling dates, 3 values per each zone, 6 for Bete Grise pooled dune and swale) against each other and against the Lake water values. For the significance level of the test, a commonly used p-value of 0.05 was used as the criterion. Additionally, 95\% confidence intervals were built around the isotopic signature means for each vegetation zone and Lake water to show the differences amongst groups.

\section{Meteorological data}

Monthly average temperature and precipitation data was obtained from the United States of America's National Oceanic and Atmospheric Administration's (NOAA) National Climatic Data Center (NCDC) Station number 14858, Houghton County

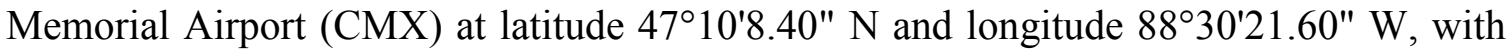
an elevation of 314 meters ASL. Controlled data dates back to December of 1889 to present day. All of the study sites, Bete Grise, Pequaming and Lightfoot Bay, are located less than $50 \mathrm{~km}$ in a straight line from the weather station.

Lake Superior levels were summarized from the verified data of the National Oceanic and Atmospheric Administration's (NOAA) Center for Operational

Oceanographic Products and Services, Great Lakes station number 9099018 in Marquette, Michigan, at latitude $46^{\circ} 32.7^{\prime} \mathrm{N}$ and longitude $87^{\circ} 22.7^{\prime} \mathrm{W}$. Lake level readings date from 1918 to 2010 . 


\section{Results}

\section{Weather conditions and the water table height}

The weather patterns of the first half of 2010 deviated from those recorded over the long term. In 2010 the precipitation summed $650 \mathrm{~mm}, 184 \mathrm{~mm}$ less than the 121 year mean of $834 \mathrm{~mm}$. The accumulated precipitation for the spring months was $76 \mathrm{~mm}$ in 2010 , substantially lower than the long-term mean of $173 \mathrm{~mm}$. In 2010, June and September received the greatest precipitation, $126 \mathrm{~mm}$ and $179 \mathrm{~mm}$, respectively (Figure 8). The long-term climatic data describes an even distribution of precipitation throughout the year, with none of the values showing more than $100 \mathrm{~mm}$ per month.

The mean daily air temperatures from 1889 to 2009 for the spring months of March, April and May in nearby Houghton, Michigan (46.4 km from the furthest peatland), were $-4.4{ }^{\circ} \mathrm{C}, 3.0^{\circ} \mathrm{C}$ and $9.8^{\circ} \mathrm{C}$, respectively. In contrast, in 2010 , the mean air temperatures were $1.9{ }^{\circ} \mathrm{C}, 7.3{ }^{\circ} \mathrm{C}$ and $12.4{ }^{\circ} \mathrm{C}$, respectively. The early and quick melting of the snow pack in March resulted in the presence of surface water at all vegetation zones of the study sites, including the upland areas. Hence the height of the water table peaked from the middle of March to early April, at the permanent study site of Pequaming complex (Figure 10). The summer of 2010 showed higher air temperatures than usual, with the mean for June, July and August being $18.4{ }^{\circ} \mathrm{C}$, in contrast with the $17.0^{\circ} \mathrm{C}$ for the longterm mean. The warmest months of the summer were July and August (Figure 8). The accumulated precipitation for the summer period was within $40 \mathrm{~mm}$ of the long-term average.

\section{Lake Superior levels}

In 2010, the annual level of Lake Superior was $0.25 \mathrm{~m}$ lower than the average recorded annual mean of $183.41 \mathrm{~m}$ ASL. Lake levels declined from January to May, which 
contrast with the long-term trend of gradual increase of the level starting from April. Lake levels of 2010 rose until mid-September and then began to decline. This fluctuation cycle matches with the long-term trend, but the overall lake level remained below the average for the entire year (Figure 9).

\section{Isotope and specific conductance measurements}

The results demonstrate that the source of water for all three sites was primarily from upland groundwater. Results from the stable oxygen isotope ratios from the three sampling dates showed distinctly different signatures to that of the lake water for all of the sites and vegetation zones (Tables 1,2).

\section{Bete Grise}

The isotopic analysis for the three measurement dates suggests that $100 \%$ of the groundwater in the peatland originated from the upland (Figure 12). The isotopic signature over the measurement period averaged $-13.4 \%$ o $\pm 0.2(95 \% \mathrm{CI})$ to $-14.0 \%$ o \pm 0.1 $(95 \% \mathrm{CI})$ for the upland and from $-13.4 \%$ o $0.9(95 \% \mathrm{CI})$ to $-14.0 \% \mathrm{o} \pm 0.8(95 \% \mathrm{CI})$ for the dune and swale complex (Table 1). The ${ }^{18} \mathrm{O} /{ }^{16} \mathrm{O}$ isotope ratios of the lake water at Bete Grise Bay averaged $(-8.84 \%$ o $\pm 0.43(95 \% \mathrm{CI}))$ and were statistically different from the peatland water (upland p-value $=0.003$, dune and swale complex p-value $=0.003$ ) water (Table 2). The upland and dune and swale complex water isotope ratios did not show a statistical difference ( $p$-value $>0.05$ ).

The specific conductance of the lake averaged $89.4 \mu \mathrm{S} / \mathrm{cm}, 76.9 \mu \mathrm{S} / \mathrm{cm}$ for the dune and swale complex and $59.9 \mu \mathrm{S} / \mathrm{cm}$ for the upland (Figure $11 \mathrm{C}$ ). The specific conductance of the upland was statistically different from lake water ( $p$-value $<0.05$ ), however, there was no statistical difference between the dune and swale complex compared to both upland and the lake water (Table 3). For the measurement period, the $\mathrm{pH}$ in the upland and the dune swale complex averaged 4.9 and 4.72 , respectively. 


\section{Pequaming}

The transition zone from upland and the open fen had up to $20 \%$ lake water in the uppermost $1 \mathrm{~m}$ of the peat column (Figure 12). Over the measurement period, the isotopic signatures averaged $-12.21 \% \pm 0.9(95 \% \mathrm{CI})$ to $-13.39 \%$ $\pm 1.54(95 \% \mathrm{CI})$ for upland, $12.27 \% \pm 0.62(95 \% \mathrm{CI})$ to $-12.57 \%$ o $\pm 0.12(95 \% \mathrm{CI})$ for the transition zone and $12.31 \% \pm 1.21(95 \% \mathrm{CI})$ to $-12.46 \% \pm 0.53(95 \% \mathrm{CI})$ for the open fen (Table 1). Lake water ${ }^{18} \mathrm{O} /{ }^{16} \mathrm{O}$ isotope ratio averaged $-8.79 \pm 0.54(95 \% \mathrm{CI})$ and was statistically different from the peatland (upland $\mathrm{p}$-value $=0.008$, transition zone $\mathrm{p}$-value $<0.001$, open fen $\mathrm{p}$ value $<0.001$ ) water (Table 2 ). The vegetation zones within the peatland did not show statistical difference in the isotope ratios ( $p$-values $>0.05)$.

The specific conductance of the lake water averaged $87.5 \mu \mathrm{S} / \mathrm{cm}, 93.5 \mu \mathrm{S} / \mathrm{cm}$ for upland, $68.7 \mu \mathrm{S} / \mathrm{cm}$ for the transition zone and $55.3 \mu \mathrm{S} / \mathrm{cm}$ for the open fen. The specific conductance of the upland differed from open fen ( $p$-value $<0.05$ ), lake water differed from transition zone ( $\mathrm{p}$-value $<0.05)$ and open fen ( $\mathrm{p}$-value $<0.05)$ (Table 3$)$. The $\mathrm{pH}$ for upland, transition zone and open fen averaged 5.92, 5.67 and 5.25, respectively.

\section{Lightfoot Bay}

Over the course of the sampling season, the isotopic signatures averaged $-12.29 \pm 0.48$ $(95 \% \mathrm{CI})$ to $-12.76 \% \pm 0.58(95 \% \mathrm{CI})$ for upland, $-12.54 \% \pm 0.64(95 \% \mathrm{CI})$ to $-12.72 \%$ $\pm 1.91(95 \% \mathrm{CI})$ for the transition zone, and $-12.29 \% \pm 1.23(95 \% \mathrm{CI})$ to $-12.66 \% \pm 1.79$ $(95 \% \mathrm{CI})$ for the open fen. Lake water ${ }^{18} \mathrm{O} /{ }^{16} \mathrm{O}$ isotope ratios at Lightfoot Bay averaged $8.78 \pm 0.7(95 \% \mathrm{CI})$ and were statistically different from the peatland (upland p-value $<0.001$, transition $\mathrm{p}$-value $=0.001$, open fen $\mathrm{p}$-value $<0.001)$ water $($ Table 2$)$. The vegetation zones within the peatland did not show statistical difference in the isotope ratios ( $\mathrm{p}$-values $>0.05)$. 
Specific conductance averaged $91.3 \mu \mathrm{S} / \mathrm{cm}$ for the lake, $95.13 \mu \mathrm{S} / \mathrm{cm}$ for the upland, 86.6 $\mu \mathrm{S} / \mathrm{cm}$ for the transition zone and $60.1 \mu \mathrm{S} / \mathrm{cm}$ for the open fen. Open fen specific conductance differed from the upland ( $\mathrm{p}$-value $<0.05$ ), lake water ( $\mathrm{p}$-value $<0.05$ ) and transition zone (p-value $<0.05$ ) (Table 3). The $\mathrm{pH}$ for the upland, transition zone and open fen averaged 5.79, 5.37 and 5.42, respectively. 


\section{Discussion}

\section{Peatland hydrology}

The combination of isotope data and specific conductance shed light on the source water for these poor fens. The isotope data clearly demonstrates that most of the water in all three fens is not from Lake water for the study period (Figure 12). Of three wetlands, only the fen complex at Pequaming may have derived a portion of its groundwater from Lake Superior during the measurement period. Therefore, the water present in each of the peatlands came from upland groundwater or rainwater.

The results of this study support past research which demonstrated that barrier enclosed coastal peatlands in the Great Lakes region are not primarily supported by lake water (Albert et al. 2005). For example, a similar study conducted in a protected barrier dune system coastal peatland of Lake Ontario showed ground water movement towards the lake despite the correlation between water-table elevation and the condition of the barrier beach (breaches in the barrier opening and closing) (Bailey and Bedford 2003).

The data does not support past work that suggested that first couple of swales closest to the beach in a dune and swale complex can have direct hydrological connection to the lake, which can continue for hundreds of meters inland (Comer and Albert 1991, Albert et al. 2005). However, this connection could be mainly dependent on the surface water from the lake that inundates the peatland. The closest ground water well to the lake, BG9, was located on the first ridge, 43 meters from the shoreline (distance calculated from GPS coordinates). The depth of well BG9 was $363 \mathrm{~cm}$ below ground elevation of the sand ridge at $185.43 \mathrm{~m} \mathrm{ASL}$, which is a greater depth than that of other wells in the site. The well reaches 1.6 meters below the annual average lake levels since 1918 . Oxygen isotope measurements do not support increasing influence of lake water with proximity to the lake for the Bete Grise dune and swale complex. When the pooled isotopic signatures from BG9 were compared to lake water in the mixing model, the source was $100 \%$ upland groundwater. The average isotopic signature of ${ }^{18} \mathrm{O} /{ }^{16} \mathrm{O}$ in well 
BG9 was $-14.27 \%$ o $(\mathrm{N}=3)$ throughout the season, while Lake Superior water at Bete Grise Bay averaged $-8.87 \%$ o $(\mathrm{N}=3){ }^{18} \mathrm{O} /{ }^{16} \mathrm{O}$ ratios. The hydraulic head at $\mathrm{BG}$, as measured by piezometric data, has shown that water is moving downward, thereby indicating that water is not moving into the area, but away from the peatland (Chimner, personal communication). Hence, it is not likely that lake water is moving into the peatland.

The isotopic data provides conclusive data that these sites are supported primarily by upland groundwater. At all three sites rainwater and evapotranspiration will further influence the isotopic composition of the fen water. Evapotranspiration will cause the peatland groundwater to become less negative. Hence, one would expect the peatland water to be heavier than its source. Since the peatland water is much lighter than the lake and, in general, heavier than the upland groundwater, the results indicate that most of the water at all sites in 2010 was from upland groundwater. At Pequaming, the up to $20 \%$ of the peatland ground water may come from the Lake. This value is based on the mixing model and likely represents the upper bound of the amount of lake water in the system because a portion of the isotopic change may result from instrument error and evapotranspiration. Evapotranspiration ration would result in the isotopic signature being less negative. Hence, evapotranspiration would make the groundwater in the peatland appear to be partially derived from the Lake. However, if the peatland groundwater originated entirely from the lake, the isotopic signature would be less negative than the lake because of evapotranspiration. However, this was not the case as the peatland groundwater more closely represents the upland groundwater. Furthermore, rainwater is not likely to be the main contributor to the water found in any of these fens. If these fens were rainwater dominated, their $\mathrm{pH}$ would consistently reflect that of a bog, rather than a fen. Except for one sampling date on Oct 26, the $\mathrm{pH}$ at these fens remained above 5, with values typically ranging between 5.1 and 5.5 (Appendix table $\mathrm{pH}$ ). These $\mathrm{pH}$ values are more indicative of a groundwater fed system (Mitch and Grosselink 2006).

The specific conductances in the peatlands differed from the upland groundwater. It is possible that the specific conductances were more similar in the spring after snow melt and then diverged because of differences in evapotranspiration driven by changing 
vegetation. Alternatively, groundwater with lower specific conductance may upwell into the peatland. This might be possible as both Lightfoot Bay and Pequaming have extensive floating mats that would not impede the flow of groundwater up from below (Boisvert 2009). For this to be true, however, the isotopic composition of the deeper groundwater would have to be nearly identical to the upland groundwater measured in this study. Therefore, this study demonstrates that groundwater is the likely the main source of water for these fens, but the mechanisms are still not entirely clear.

\section{Temporal changes in the stable isotope data}

The relatively stable readings for oxygen isotopes of groundwater and Lake Superior water samples of this study can reflect the temporal scale limitation of three sampling dates over the course of four months. An extensive groundwater study conducted by Huddart et al. (1998) of a transient barrier sand-bar that separates a coastal freshwater marsh from Lake Erie, Canada, showed high spatial and temporal variability in the marsh water $\left(\delta{ }^{18} \mathrm{O}-8.4 \%\right.$ to $-0.1 \%$ ) compared to relatively stable Lake water $\left(\delta{ }^{18} \mathrm{O}=-7.5 \%\right.$ to $-6.7 \%$ VSMOW) over the period of 21 months. The benefit of extensive sampling helped determine that groundwater flowed from the marsh to the lake during winter months, but the flow reversed the following spring, and again the following autumn. The effect of spring-melt recharge was noticeable as the head reversed and the total distance of groundwater travelling back and forth was determined to be at least 96 meters per year (Huddart et al. 1998). Similarly with the Lake Erie study (Huddart et al. 1998) the isotopic signature of precipitation fell within the brackets of local meteoric water lines of $\delta{ }^{18} \mathrm{O}=-10 \%$ to $-15 \%$, suggested by Dansgaard (1964) and Hoffmann et al. (2000). A flow reversal could occur in the peatlands in the present study if Lake Superior levels were higher. 


\section{Potential influence of fluctuating lake levels}

In the past, the Lake Superior region has been influenced by altering climatic conditions. About 5,000 years B.P. the Upper Midwest region of North America shifted from a warm and dry climate to cooler and wetter conditions (Delcourt et al. 2002). The shift occurred because previously dominated dry North Pacific air gave way to increased transport of warm and moist air from the Gulf Coast during summer, and a combination of Pacific and Gulf air masses during winter (Delcourt et al. 2002). This has resulted in an increase in the precipitation events that could affect the source water for coastal peatlands in Lake Superior.

The absolute recorded lake level minimums for August and September occurred in 2007, when Lake Superior levels reached $183.01 \mathrm{~m}$ ASL and $183.02 \mathrm{~m} \mathrm{ASL}$, respectively. The minimums for all the other months occurred in the 1920s (NOAA, NWS Marquette, MI 2011). Lake Superior minimum monthly mean levels usually occur at the end of the winter season, because during winter months, the dominating western winds carry dry air masses through the area, which then obtain moisture from the lake surface. This subsequently results in exceptionally heavy, lake effect snowfalls along the southern and eastern shore of Lake Superior. According to Delcourt et al. (2002) the lake effect precipitation events driven by the midwinter (from November to March) frigid air from Canada reach up to $100 \mathrm{~km}$ inland in the western Great Lakes region.

In 2010, Lake Superior levels averaged to an annual level $183.16 \mathrm{~m}$ ASL, which is only slightly lower than the long term average of $183.41 \mathrm{~m}$. Higher lake levels could result in a greater Lake water influence on groundwater at these peatlands. In particular, the groundwater at Pequaming could experience the greatest lake water influence, because it is the closest to the lake elevation (Figure 6) and is exposed to the lake from two sides (Figure 3).

The lake level influence observed in the open fen and transition zone of Pequaming, however, does not extrapolate to the whole open fen section. The limiting 
factor is that the transect of ground water monitoring wells was in the middle of the peatland, which is approximately 800 meters from the closest shoreline of Lake Superior. Additionally, there was no isotope water sample collected from the more hydraulically conductive and thus semi-transient sand barrier regions that isolate the peatland complex from the lake (Figure 3). In central portion of Pequaming peatland complex up to $20 \%$ of the ground water in the open fen and transitional vegetation zones may come from lake water (Figure 12). However, there was no data collected from proximity of the barriers that border the peatland in the northeast and southwest. The potential lake water intrusion to the site would occur after a very dry summer which draws down the groundwater at the peatland, while Lake Superior reaches its annual maximum in August and September (Figure 9). This is further supported by the fact that the open floating mat portion of Pequaming is roughly only $31 \mathrm{~cm}$ (183.7 m ASL) higher from Lake Superior long term recorded mean of $183.41 \mathrm{~m} \mathrm{ASL}$. According to the long term monthly maximum levels, lake levels could be higher during 8 months of the year and, thus, inundate the Pequaming floating mat portion (Figure 6).

Other coastal freshwater wetlands in the Great Lakes region are occasionally inundated by lake water. For example, a coastal freshwater marsh study conducted by Huddart et al. (1999) at Lake Erie, Canada, determined two sources of water inputs: precipitation and groundwater discharge. However, in a decadal time scale Lake Erie occasionally inundates the marsh, when a portion of the isolating coastal sand barrier disintegrates because of wave action (Huddart et al. 1999). The southwestern barrier of Pequaming complex has a culvert beneath the road that runs along the barrier that could be an outlet of surface water for exceptionally high water levels in the open floating fen mat after spring-melt, or provide direct inlet into the peatland in the event of higher Lake Superior levels.

It is assumed, that the large ground water dominance at Pequaming is solely driven by the hydraulic head of adjacent upland bordering the southern edge. To determine exact interactions with the lake, an extensive network of piezometers and water level monitoring systems would have to be established. 


\section{Conclusion}

This study demonstrates that despite Lake Superior contributing to the formation of these sites, they are mostly supported by groundwater input s from adjacent upland areas. The hypothesis that groundwater at Pequaming was primarily lake water dominated because the peatland was the most exposed to the lake was refuted. However, it is the only site that was moderately influenced by Lake and had partial presence of lake water in the groundwater mix. It is likely that the proportion of lake water present in the subsurface areas of transition zone and open fen at Pequaming are affected by snowmelt during springtime, and in longer temporal scale, Lake Superior water level fluctuations. Since records begin in 1918, Lake Superior water levels have reached higher levels than the open floating mat fen at Pequaming during 8 months of the year, suggesting that the open fen at Pequaming is periodically inundated with lake water. 


\section{List of References}

Aaby B. 1986. Paleoecological studies of mires. Pages 145-164 in B. E. Berglund, editor. Handbook of Holocene palaeoecology and palaeohydrology. John Wiley \& Sons, New York, New York, U.S.A.

Albert DA, Wilcox DA, Ingram JW, Thompson TA. 2005. Hydrogeomorphic classification for Great Lakes coastal wetlands. Journal of Great Lakes Research. 31:129-146.

Amon JP, Thompson CA, Carpenter QJ, Miner J. 2002. Temperate zone fens of the glaciated Midwestern USA. Wetlands. 22(2):301-317.

Baedke SJ, Thompson TA, Johnston JW and Wilcox DA. 2004. Reconstructing Paleo Lake Levels from Relict Shorelines along the Upper Great Lakes. Special Issue on Lake Superior. Aquatic Ecosystems Health \& Management. 7:435-449.

Bailey KM and Bedford BL. 2003. Transient geomorphic control of water table and hydraulic head reversals in a coastal freshwater peatland. Wetlands. 23(4):969978.

Bartlett KB and Harriss RC. 1993. Review and assessment of methane emissions from wetlands. Chemosphere. 26:261-320.

Boisvert EA. 2009. Initiation and Development of Three Lake Superior Coastal Peatlands. School of Forest Resources and Environmental Science. Houghton, MI, Michigan Technological University. M.S. 75 p.

Booth RK, Jackson ST, Thompson TA. 2002. Paleoecology of a northern Michigan lake and the relationship among climate, vegetation, and Great Lakes water levels. Quaternary Research. 57(1):120-130. 
Botch MS and Masing VV. 1983. Mire ecosystems in the U.S.S.R. Pages 95-152 in A. J. P. Gore, editor. Eco-systems of the world, 4B. Mires: swamp, bog, fen and moor, Regional studies. Elsevier, Amsterdam, The Netherlands.

Bridgham SD, Pastor J, Janssens J, Chapin C and Malterer T. 1996. Multiple limiting gradients in peatlands: a call for a new paradigm. Wetlands. 16:45-65.

Bridgham SD, Updegraff K, and Pastor J. 1998. Carbon, nitrogen, and phosphorus mineralization in northern wetlands. Ecology. 79(5):1545-1561.

Charman D. 2002. Peatlands and environmental change. Chichester, England: John Wiley \& Sons Ltd. 301 p.

Chimner RA, Cooper DJ. 2004. Using stable oxygen isotopes to quantify the water source used for transpiration by native shrubs in the San Luis Valley, Colorado USA. Plant and Soil. 260(1-2):225-236.

Chimner RA, Karberg J. 2008. Long-term carbon accumulation in two tropical mountain peatlands, Andes Mountains, Ecuador. Mires and Peat 3:Art. 4.

Comer PJ and Albert DA. 1991. A Survey of Wooded Dune and Swale Complexes in the Northern Lower and Eastern Upper Peninsulas of Michigan. Michigan Natural Features Inventory, Lansing, MI.

Coordinate Distance Calculator. An online tool available from http://boulter.com/gps/distance/ Accessed [2011-01-06]

Dansgaard W. 1964. Stable isotopes in precipitation. Tellus. 16:436 - 468.

Dau JHC. 1823. Neues Handbuch über den Torf. JC Hinrichsche Buchhandlung, Leipzig, Germany.

Dawson TE. 1993. Water sources of plants as determined from xylem-water isotopic composition: Perspectives on plant competition, distribution and water relations. 
In Stable isotopes and plant carbon-water relations. Eds. J R Ehleringer, A E Hall, and G D Farquhar. pp. 465-496. Academic Press, San Diego.

Dawson TE and Ehleringer JR. 1991. Streamside trees that do not use stream water: evidence from hydrogen isotope ratios. Nature. 350:335-337.

Delcourt PA, Nester PL, Delcourt HR, Mora CI, Orvis KH. 2002. Holocene lake-effect precipitation in northern Michigan. Quaternary Research. 57(2):225-233.

Doonan CJ and Byerlay JR. 1973. Water investigation 11: Ground water and geology of Baraga County, Michigan. State of Michigan Department of Natural Resources, Geological Survey Division, Lansing, Michigan.

Drexler JZ, Bedford BL, Scognamiglio R, Siegel DI. 1999. Fine-scale characteristics of groundwater flow in a peatland. Hydrological Processes. 13(9):1341-1359.

Feng X. 2002. A theoretical analysis of carbon isotope evolution of decomposing plant litters and soil organic matter. Global Biogeochemical Cycles. 16:1119. DOI 10.1029/2002GB001867.

Francez AJ, Vasander H. 1995. Peat accumulation and peat decomposition after human disturbance in French and Finnish mires. Acta Oecologica. 16:599-608.

Fraser CJD, Roulet NT, Lafleur PM. 2001. Groundwater flow patterns in a large peatland. Journal of Hydrology. 246:142-154.

Gignac LD, Vitt DH. 1994. Responses of Northern Peatlands to Climate Change: Effects on Bryophytes. Journal of the Hattory Botanical Laboratory. 15:119-132.

Glaser PH, Chanton JP, Morin P, Rosenberry DO, Siegel DI, Ruud O, Chasar LI, Reeve AS. 2004. Surface deformations as indicators of deep ebullition fluxes in a large northern peatland. Global Biogeochemical Cycles. 18:GB1003. DOI 10.1029/2003 GBO02069. 
Glatzel SN, Basiliko N, Moore TR. 2004. Carbon dioxide and methane production potentials of peats from natural, harvested and restored sites, eastern Québec, Canada. Wetlands. 24:261-267.

Gore AJ. 1983. Ecosystems of the world. Mires: swamp, bog, fen and moor. 4A, General studies, and 4B, Regional studies. Elsevier, Amsterdam, The Netherlands.

Gorham E. 1953. Some early ideas concerning the nature, origin, and development of peat lands. Journal of Ecology. 41:257-274.

Gorham E. 1991. Northern Peatlands - Role in the Carbon-cycle and Probable Responses to Climatic Warming. Ecological Applications. 1(2):182-195.

Gorham E, Eisenreich SJ, Ford J, Sandtelmann MV. 1985. The chemistry of bog waters. In: Stumm W (ed) The chemical processes in lakes. Wiley, New York, pp 330363.

Gorham E, Janssens J. 1992. Concepts of fen and bog reexamined in relation to bryophyte cover and the acidity of surface waters. Acta Societatis Botanicorum Poloniae. 61:7-20.

Hemond HF. 1980. Biogeochemistry of Thoreau's Bog. Concord, Massachusetts. Ecological Monographs. 50:507-526.

Herdendorf CE. 1992. Lake Erie Coastal Wetland - An Overview. Journal of Great Lakes Research. 18(4):533-551.

Hoffmann GJ, Jouzel, Masson V. 2000. Stable water isotopes in atmospheric general circulation models. Hydrological Processes. 14(8):1385-1406.

Houghton JT, Callander BA and Varney SK. 1992. Climate change 1992: the supplementary report to the IPCC scientific assessment. Cambridge University Press, Cambridge, UK. 
Hsu JRC and Silvester R. 1990. Accretion Behind Single Ooffshore Breakwater. Journal of Waterway, Port, Coastal, and Ocean Engineering-ASCE. 116(3):362-380.

Huddart PA, Longstaffe FJ, Crowe AS. 1999. Delta D and delta O-18 evidence for inputs to groundwater at a wetland coastal boundary in the southern Great Lakes region of Canada. Journal of Hydrology. 214(1-4):18-31.

Immirzi CP, Maltby E and Clymo RS. 1992. The Global Status of Peatlands and their Role in Carbon Cycling. A report for the Friends of the Earth by the Wetland Ecosystems Research Group, Department of Geology, University of Exeter. Friends of the Earth, London.

Ingram HAP. 1978. Soil layers in mires: function and terminology. Journal of Soil Science. 29:224-227.

Ingram HAP. 1983. Hydrology. In: Gore AJP (ed) Ecosystems of the world 4A. Mires: swamp, bog, fen, and moor. General studies. Elsevier, Amsterdam, pp 67-158.

Jaworski E and Raphael CN. 1978. Fish, wildlife and recreational values of Michigan's coastal wetlands. U.S. Fish \& Wildlife Service, Twin Cities, MN.

Joosten H, Clarke D. 2002. The Wise Use of Mires and Peatlands - Background and Priciples including a Framework for Decision-making. International Mire Conservation Group \& International Peat Society.

Kelley CA, Dise NB, Martens CS. 1992. Temporal variations in the stable carbon isotopic composition of methane emitted from Minnesota peatlands. Global Biogeochemical Cycles. 6:263-269.

Lappalainen E. 1996. General review on world peatland and peat resources. p. 53-56. In E. Lappalainen (ed.) Global Peat Resources. International Peat Society and Geological Survey of Finland, Jyska, Finland. 
Malmer N. 1986. Vegetational gradients in relation to environmental conditions in northwestern European mires. Canadian Journal of Botany. 64(2):375-383.

Malmer N, Horton DG, Vitt DH. 1992. Element Concentrations in Mosses And Surface Waters Of Western Canadian Mires Relative To Precipitation Chemistry And Hydrology. Ecography. 15(1):114-128.

Meehl G. 2007. Global climate projections, in Climate Change 2007: The Physical Science Basis, edited by Solomon S, Qin D, Manning M, Chen Z, Marquis M, Averyt KB, Tignor M and Miller HL, pp. 747 - 845, Cambridge University. Press, New York, NY, U.S.A.

Merlivat L, Jouzel J. 1979. Global climatic interpretation of the deuterium-oxygen 18 relationship for precipitation. Journal of Geophysical Research. 84:5029-5033.

Mitch WJ and Gosselink JG. 2000. Wetlands, 3rd Edition. John Wiley \& Sons, Inc. New York.

Moore TR, Bubier JL, Frolking SE, Lafleur PM, Roulet NT. 2002. Plant biomass and production and $\mathrm{CO} 2$ exchange in an ombrotrophic bog. Journal of Ecology. 90:25-36.

Moore TR, Dalva M. 1993. Influence of temperature and water table position on carbon dioxide and methane emissions from columns of peatland soils. Journal of Soil Science. 44:651-664.

National Oceanic and Atmospheric Administration's (NOAA) Center for Operational Oceanographic Products and Services, Great Lakes station number 9099018 in Marquette, Michigan. Website. http://www.weather.gov/climate/index.php?wfo=mqt [accessed 201101-10] 
Neishtadt MI. 1977. The world's largest peat basin, its commercial potentialities and protection. International Peat Society Bulletin. 8:37-43.

Neustadt MI. 1984. Holocene peatland development. Pages 201-206 in A. A. Velichko, editor. Late Quatemary envi- ronments of the Soviet Union. University of Minnesota Press, Minneapolis, Minnesota, USA.

Page SE, Siegert F, Rieley JO, Boehm HDV, Jaya A, Limin S. 2002. The amount of carbon released from peat and forest fires in Indonesia during 1997. Nature. 420(6911):61-65.

Podniesinski GS and Leopold DJ. 1998. Plant community development and peat strategy in forested fens in response to ground-water flow systems. Wetlands. 18(3):409430.

Reeve AS. 1996. Numerical and multivariate statistical analysis of hydrogeology and geochemistry in large peatlands. PhD dissertation, Syracuse University, Syracuse.

Ronkanen AK and Klove B. 2007. Use of stabile isotopes and tracers to detect preferential flow patterns in a peatland treating municipal wastewater. Journal of Hydrology. 347(3-4):418-429.

Rosa E, Larocque M. 2008. Investigating peat hydrological properties using field and laboratory methods: application to the Lanoraie peatland complex (southern Quebec, Canada). Hydrological Processes. 22:1866-1875.

Rydin H, Jeglum JK. 2006. The Biology of Peatlands. Oxford University Press. 354 p.

Siegel DI and Glaser PH. 2006. The Hydrology of Peatlands, In: Boreal Peatland Ecosystems, Ed. R. Kelman Wieder and Dale H. Vitt, Springer Berlin Heidelberg. p. 289-311 
Siegel DI, Glaser PH, So J, Janecky DR. 2006. The dynamic balance between organic acids and circumneutral groundwater in a large boreal peat basin. Journal of Hydrology. 320(3-4):421-431.

Sjörs H. 1963. Bogs and fens on Attawapiskat River, northern Ontario. National Museum of Canada Bulletin Contributions to Botany. 171:1-31.

Tolonen K. 1979. Peat as a renewable resource: long-term accumulation rates in northeuropean mires. In: Kivinen E, Heikurainen L, Pakarinen $\mathrm{P}$ (eds) Classification of peat and peatlands. International Peat Society, Helsinki, Finland, pp 282-296.

Tolonen K, Vasander H, Damman AWH, Clymo RS. 1992. Preliminary estimate of longterm carbon accumulation and loss in 25 boreal peatlands. Suo. 43:277-280.

Turunen J, Tahvanainen T, Tolonen K, Pitkänen A. 2001. Carbon accumulation in West Siberian mires, Russia. Global Biogeochemical Cycles. 15:285-296.

Vitt DH. 2000. Peatlands: ecosystems dominated by bryophytes. In: Shaw AJ, Goffinet B (eds) Bryophyte biology. Cambridge University Press, Cambridge, pp 312-343.

Walter H. 1977. The oligotrophic peatlands of Westem Siberia-the largest peinohelobiome in the world. Vegetatio. 34:167-178.

Warner BG, Clymo RS, Tolonen K. 1993. Implications of peat accumulation at Point Escuminac, New Brunswick. Quaternary Research. 39:245-248.

Watterson IG. 2008. Calculation of probability density functions for temperature and precipitation change under global warming. Journal of Geophysical Research. 113, D12106, doi: 10.1029/2007JD009254.

Weber CA. 1902. Über die Vegetation und Entstehung des Hochmoors von Augstumal im Memeldelta mit vergleichenden Ausblicken auf andere Hochmoore der Erde. Parey, Berlin, Germany. 
Wheeler BD, Proctor MCF. 2002. Ecological gradients, subdivisions and terminology of north-west European mires. Journal of Ecology. 88:187-203.

Wieder RK, Vitt HD, 2006. ed. Boreal Peatland Ecosystems. Ecological Studies, ed. D. Czeschlik. Vol. 188. Springer-Verlag Berlin Heidelberg.

Wilcox WM, Solo-Gabriele HM, Sternberg LOR. 2004. Use of stable isotopes to quantify flows between the Everglades and urban areas in Miami-Dade County Florida. Journal of Hydrology. 293(1-4):1-19.

Yavitt JB, Williams CJ and Wieder RK. 1997. Production of methane and carbon dioxide in peatland ecosystems across North America: effects of temperature, aeration, and organic chemistry of peat. Geomicrobiology Journal. 14:299-316.

YSI Model 63 Handheld pH, Conductivity, Salinity and Temperature System. Operations Manual. 1998 YSI Incorporated, 1725 Brannum Lane Yellow Springs, Ohio 45387 USA. 
Figures and Tables

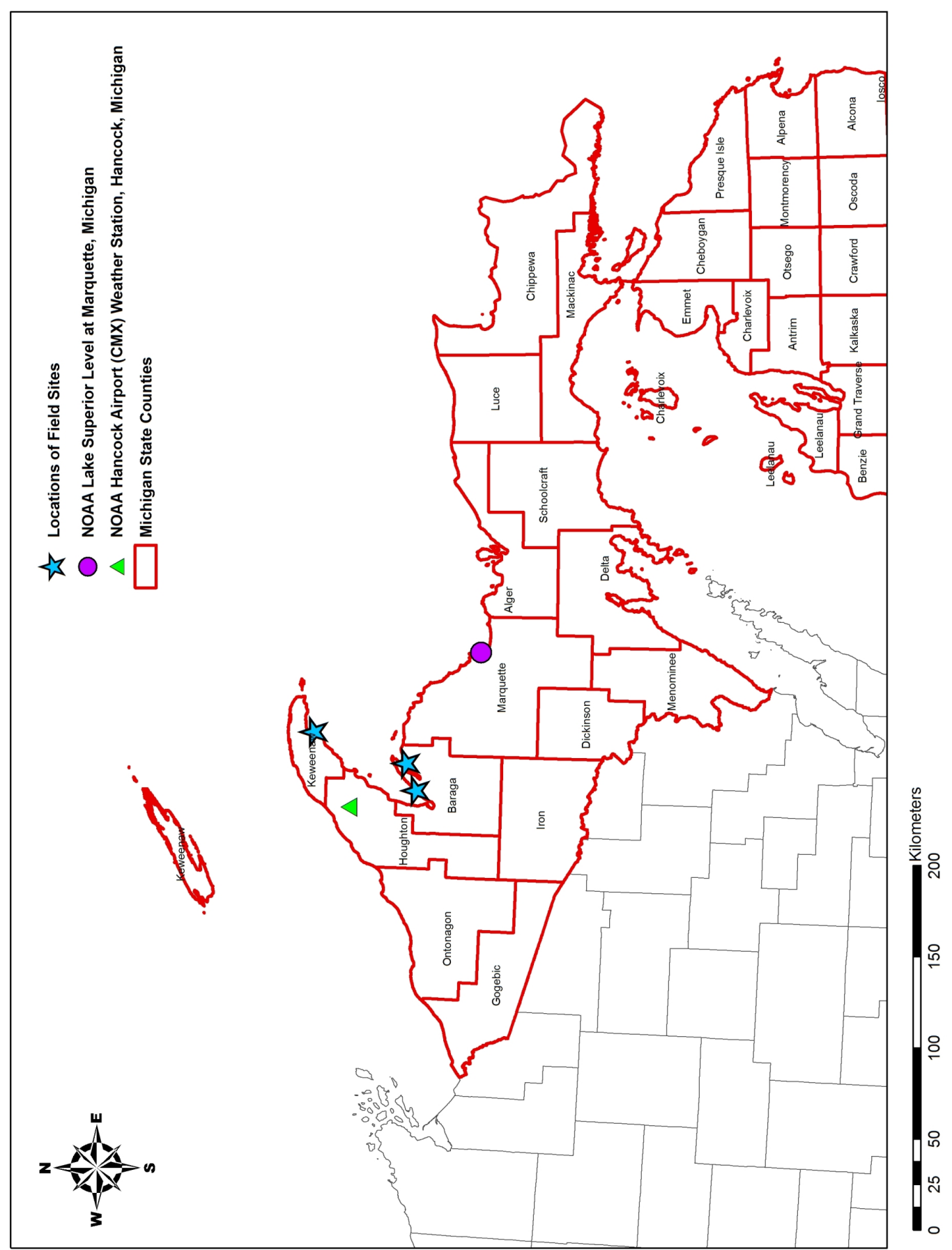

Figure 1. Study sites in the vicinity of the Keweenaw Peninsula in Upper Michigan of the United States 


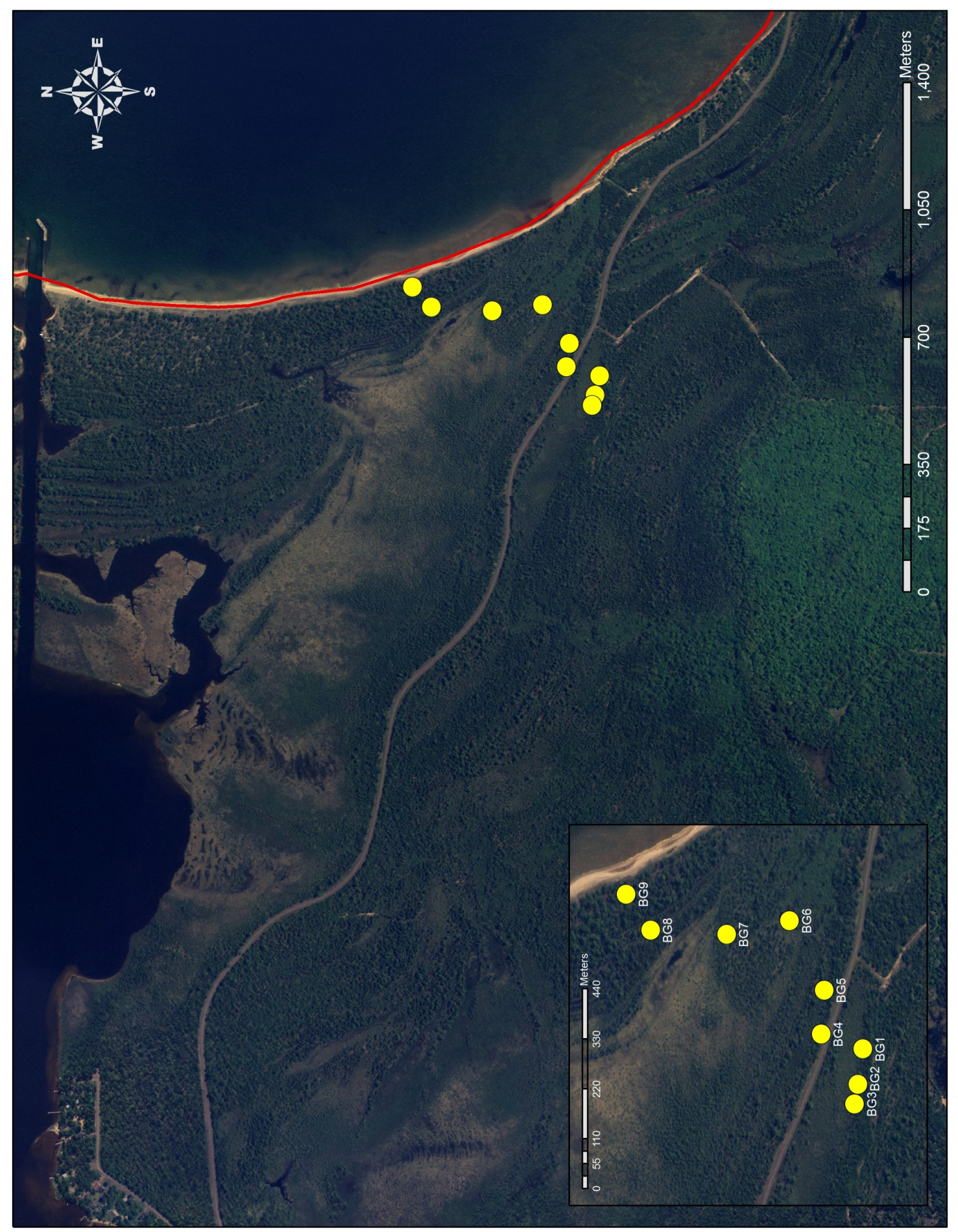

Figure 2. Transect of installed wells at Bete Grise 


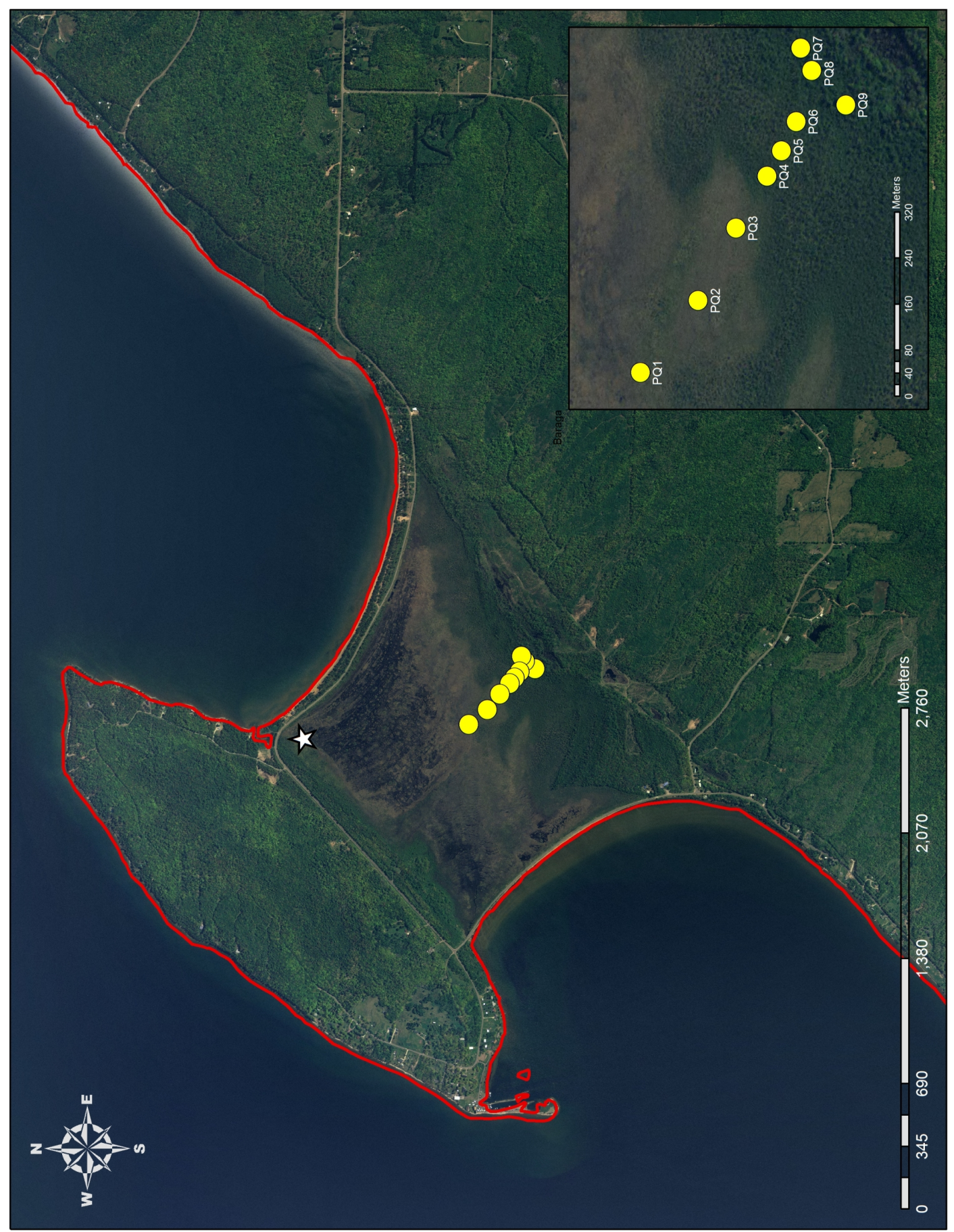

Figure 3. Transect of ground water monitoring wells at the tombolo peatland, Pequaming. The star marks the position of the permanent study site with the water table logger 


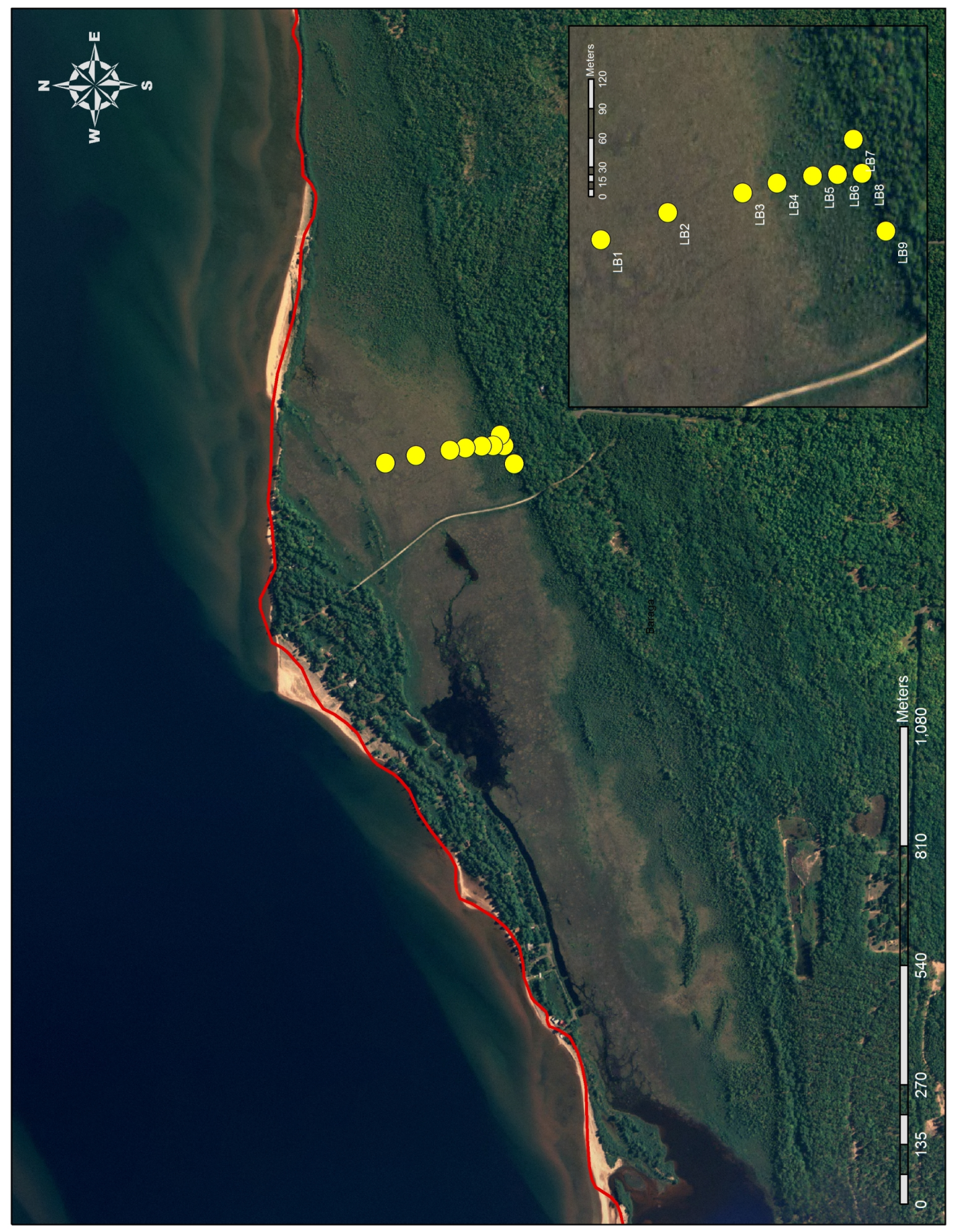

Figure 4. Transect of ground water monitoring wells at Lightfoot Bay peatland complex 


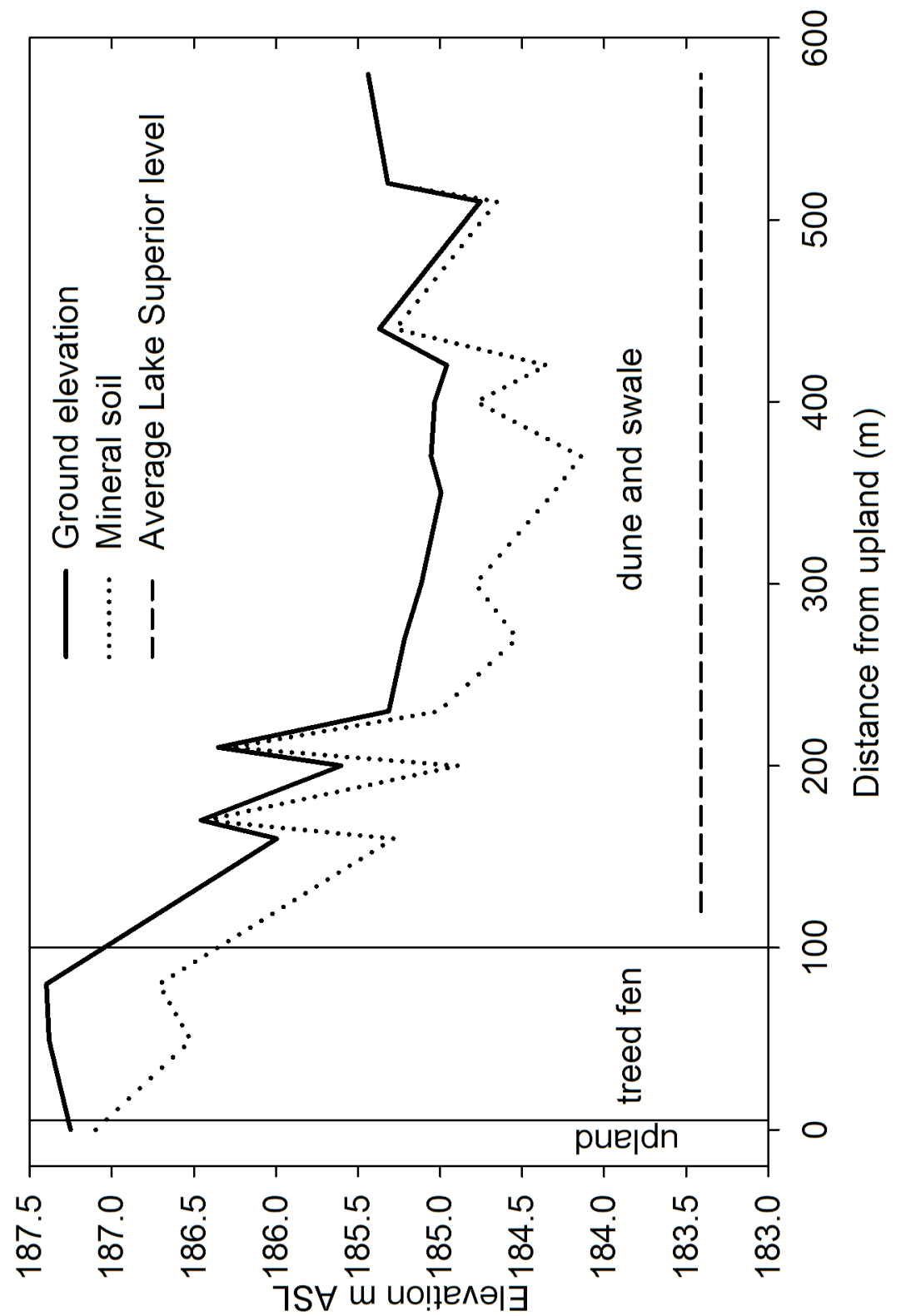

Figure 5. Cross section of probed peat depths of Bete Grise dune and swale complex 


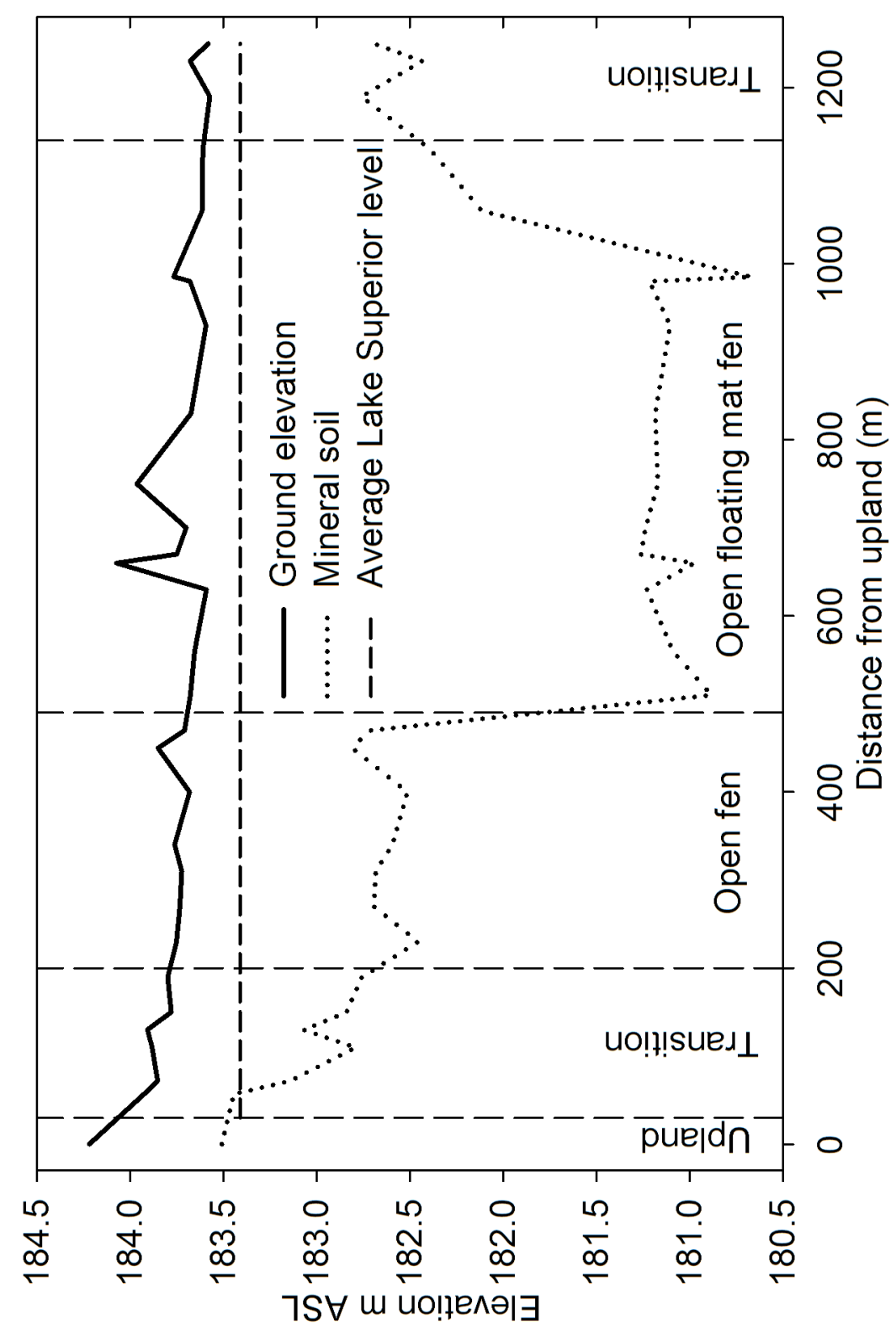

Figure 6. Cross section of probed peat depths of the Pequaming peatland complex 


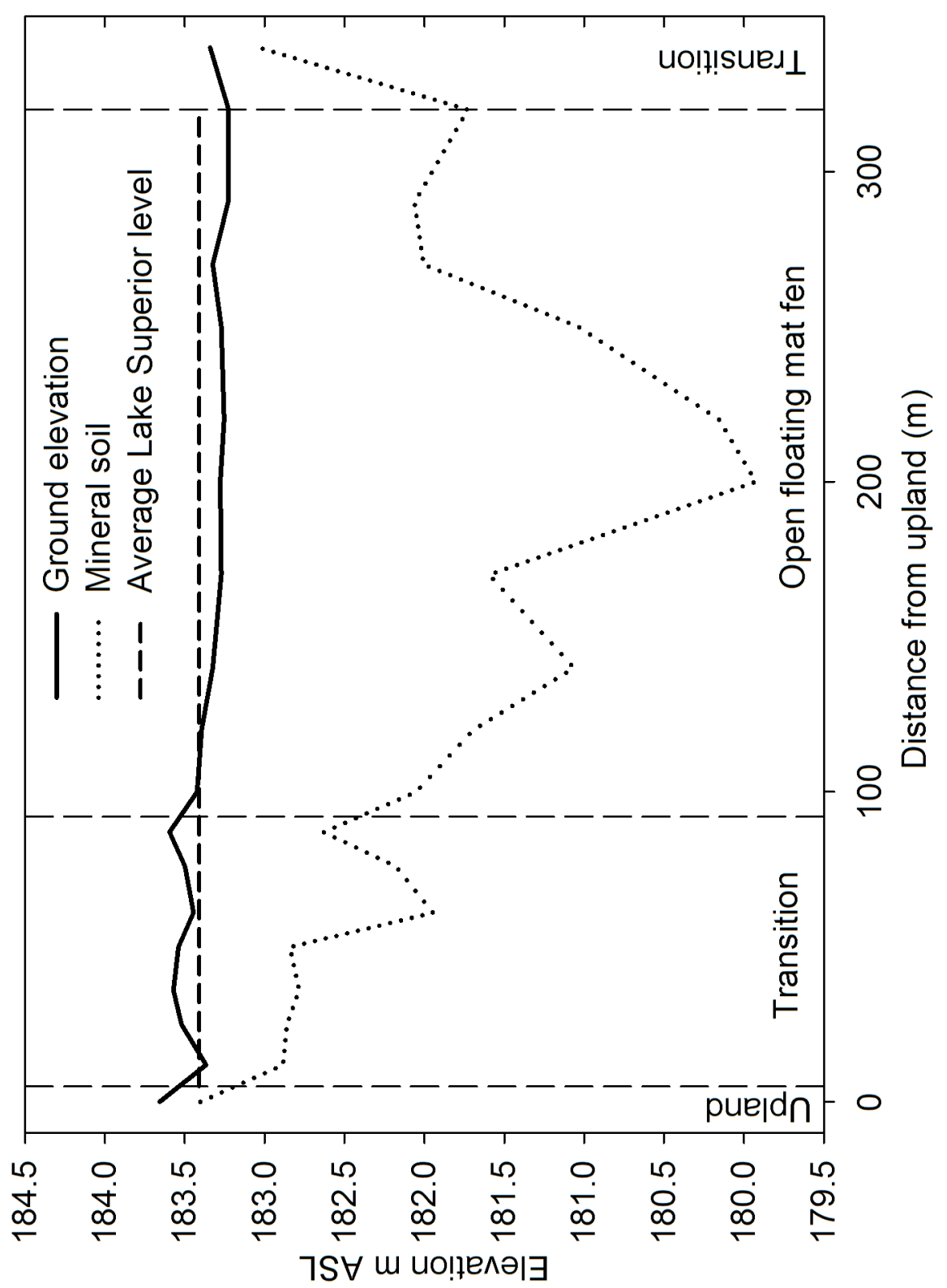

Figure 7. Cross section of probed peat depths of Lightfoot Bay peatland complex 


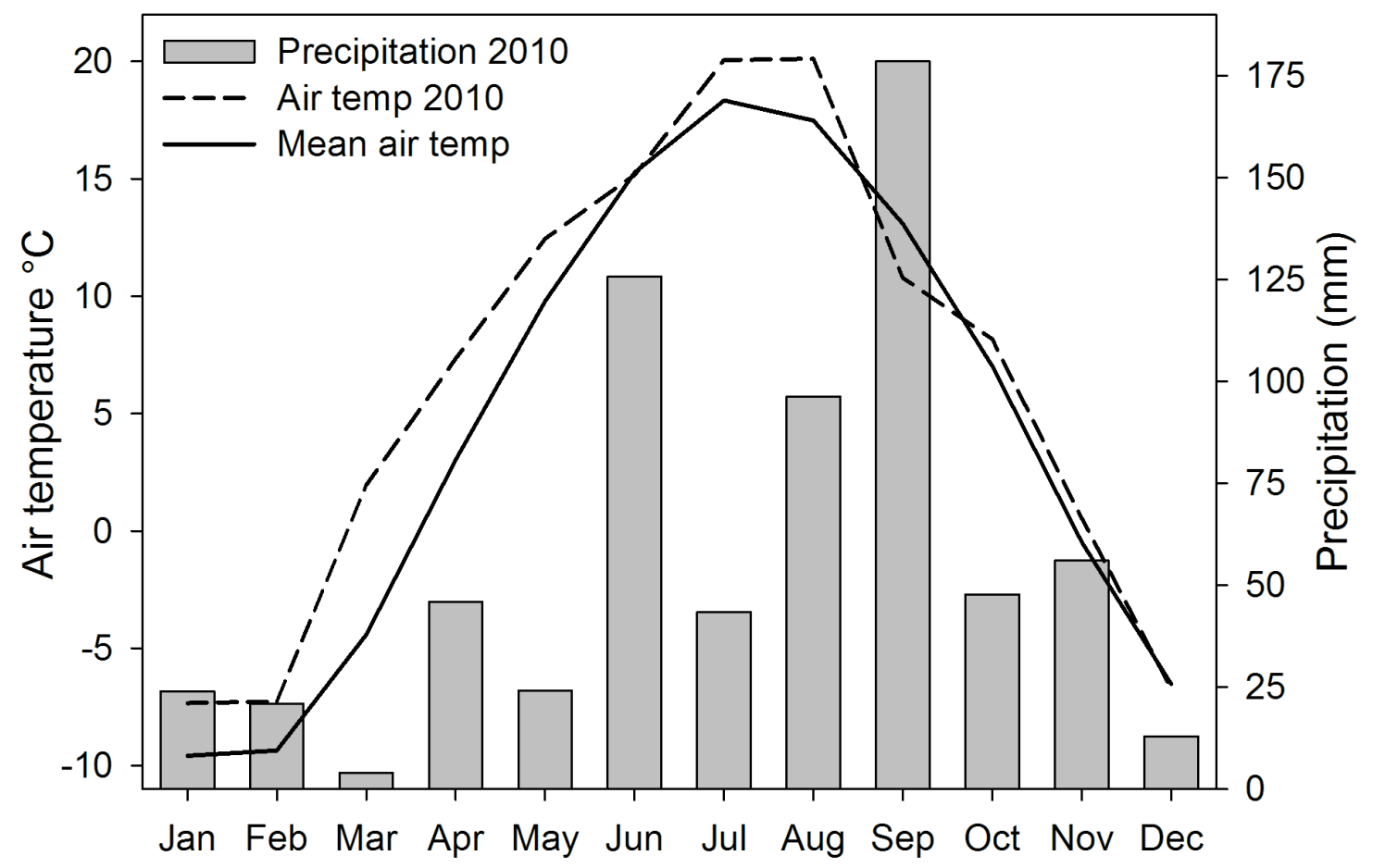

Figure 8. Houghton County mean daily air temperatures and monthly accumulated precipitation, Jan 2010 to Dec 2010. Long term mean temperature data dates from 1889 to 2009 


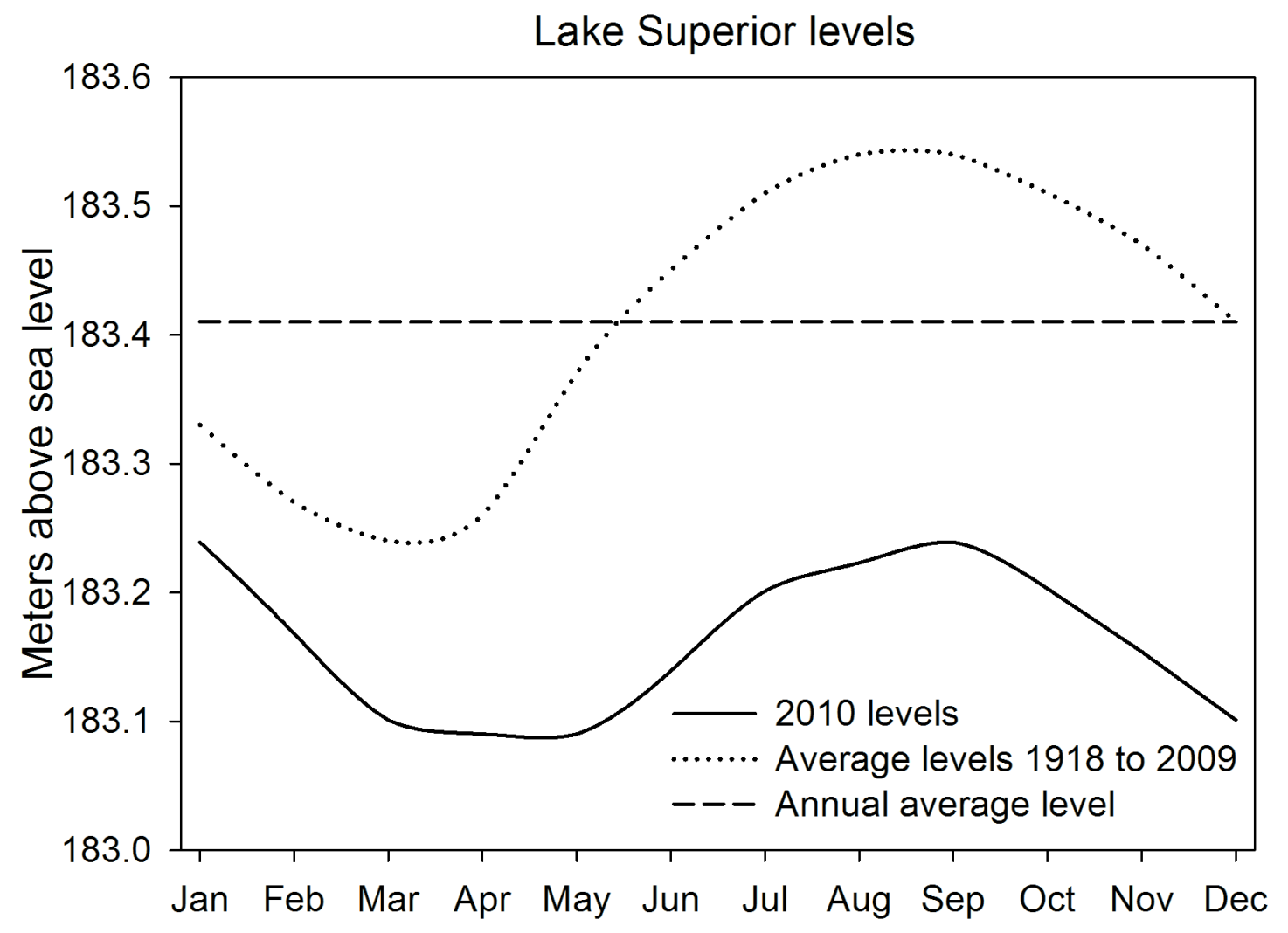

Figure 9. Lake Superior monthly levels of 2010, average monthly levels from 1918 to 2009, and annual average level 


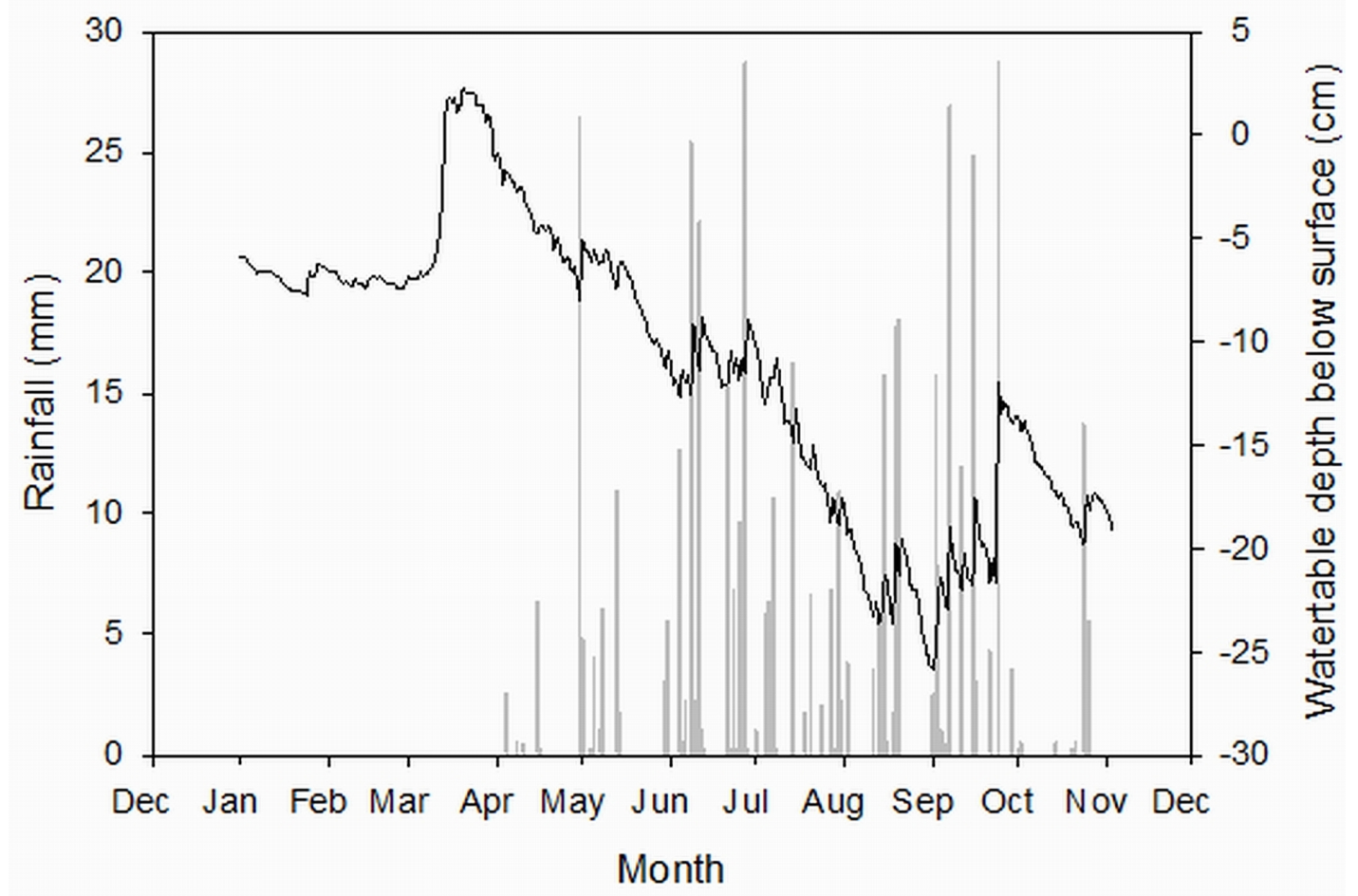

Figure 10. Water table height and precipitation at Pequaming 


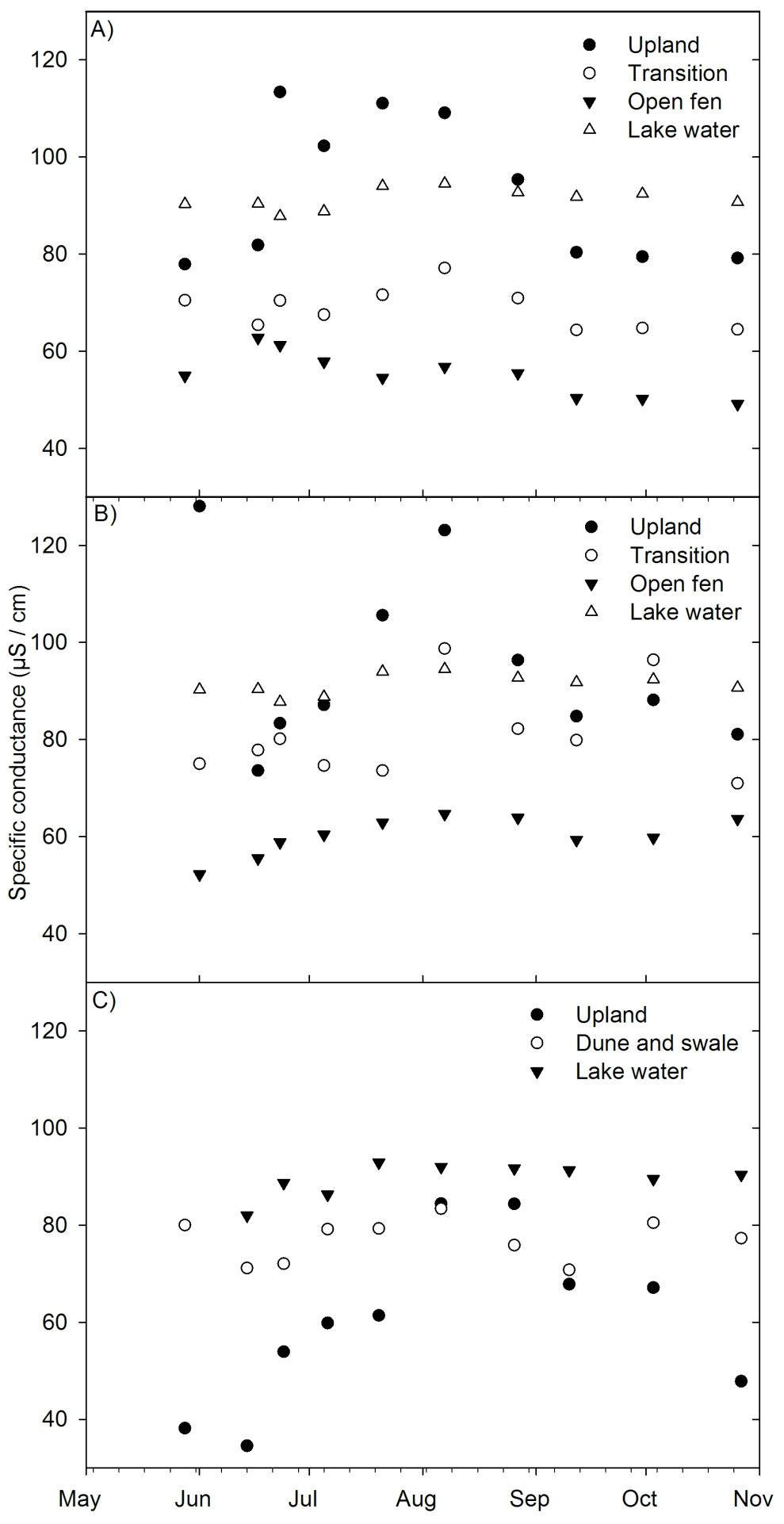

Figure 11: Specific conductance at all sites (A) Pequaming, (B) Lightfoot Bay, (C) Bete Grise 


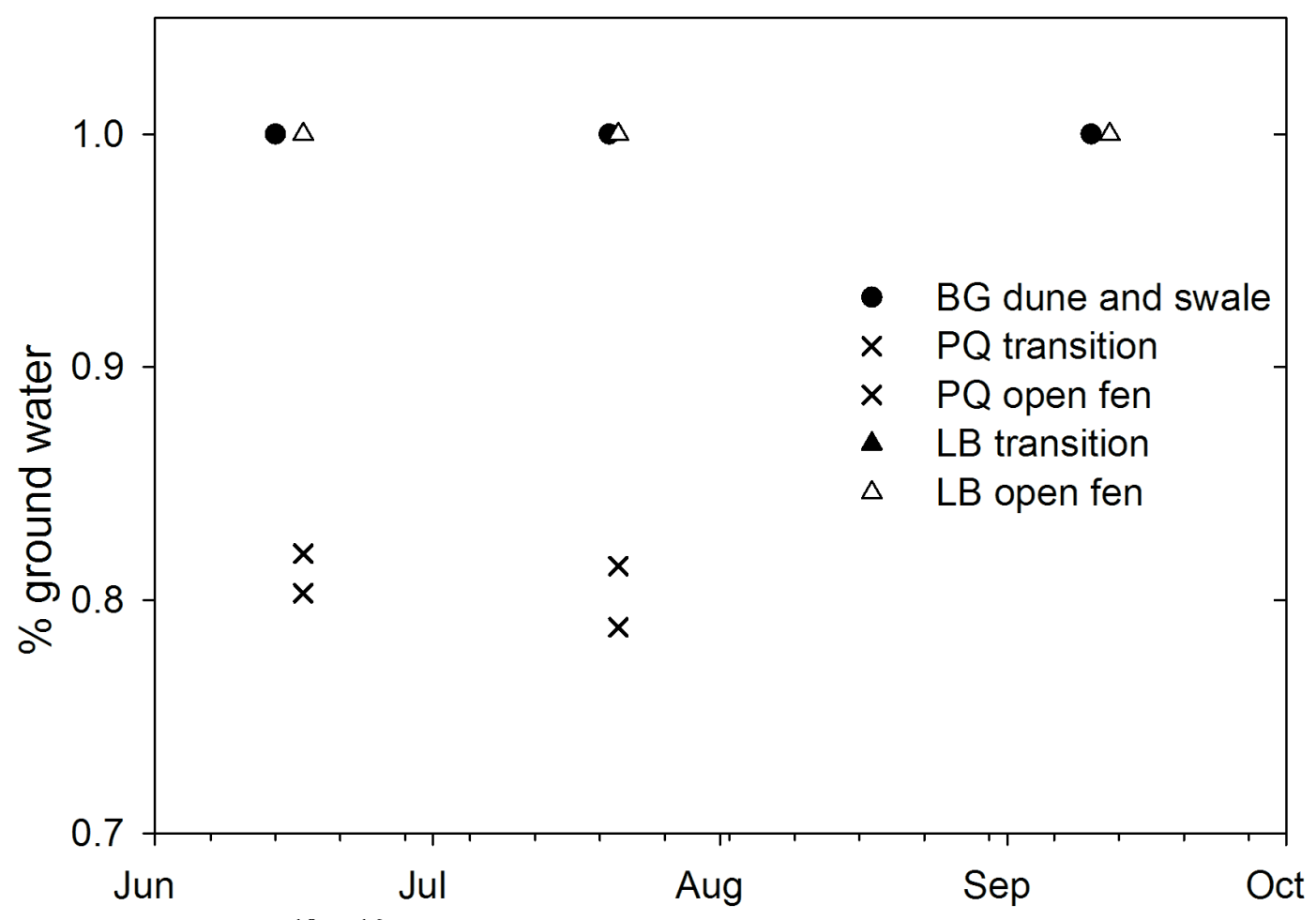

Figure 12. Delta ${ }^{18} \mathrm{O} /{ }^{16} \mathrm{O}$ isotope ratios showing the amount of ground water supporting each site. Note that Pequaming (PQ) is missing the third sampling date due to potential sampling error from surface water 


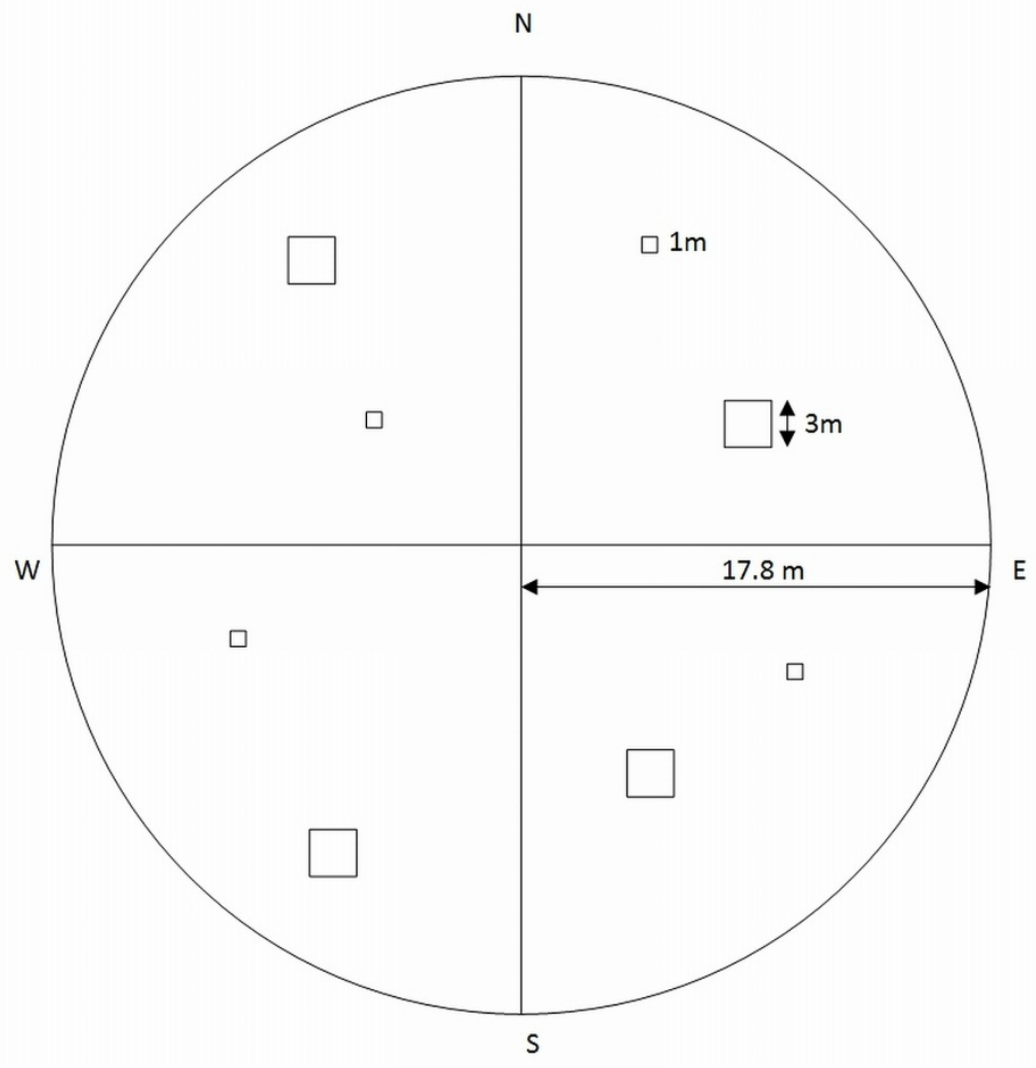

Figure 13: Layout of the 0.1 ha circular vegetation survey plots. The circle was divided into four quarters according to cardinal directions. $3 \times 3 \mathrm{~m}$ plots were used for shrub layer sampling and $1 \times 1 \mathrm{~m}$ plots for the herbaceous layer, all placed randomly within the quarters. 
Table 1.

${ }^{18} \mathrm{O}$ stable oxygen isotope ratios of all sites with $95 \%$ confidence intervals

\begin{tabular}{|c|c|c|c|c|}
\hline Site & Vegetation & $14-17.06 .2010$ & $20-21.07 .2010$ & $10-12.09 .2010$ \\
\hline \multirow{3}{*}{ Bete Grise } & Upland & $-13.44 \pm 0.16$ & $-13.47 \pm 0.2$ & $-13.97 \pm 0.13$ \\
\hline & Dune and swale & $-13.46 \pm 0.91$ & $-13.39 \pm 0.92$ & $-13.99 \pm 0.82$ \\
\hline & Lake water & -9.00 & -8.87 & -8.65 \\
\hline \multirow{4}{*}{ Pequaming } & Upland & $-13.18 \pm 0.45$ & $-13.39 \pm 1.54$ & $-12.21 \pm 0.9$ \\
\hline & Transition & $-12.27 \pm 0.62$ & $-12.57 \pm 0.12$ & $-12.34 \pm 0.2$ \\
\hline & Open fen & $-12.33 \pm 0.98$ & $-12.46 \pm 0.53$ & $-12.31 \pm 1.21$ \\
\hline & Lake water & -8.55 & -8.99 & -8.82 \\
\hline \multirow{4}{*}{ Lightfoot Bay } & Upland & $-12.29 \pm 0.48$ & $-12.46 \pm 0.75$ & $-12.76 \pm 0.58$ \\
\hline & Transition & $-12.54 \pm 0.64$ & $-12.56 \pm 1.17$ & $-12.72 \pm 1.91$ \\
\hline & Open fen & $-12.29 \pm 1.23$ & $-12.46 \pm 1.34$ & $-12.66 \pm 1.79$ \\
\hline & Lake water & -8.45 & -8.94 & -8.94 \\
\hline
\end{tabular}

Table 2.

Student's pairwise comparison of ${ }^{18} \mathrm{O}$ isotope ratios between vegetation zones and lake water

\begin{tabular}{|l|l|}
\hline \multicolumn{2}{|c|}{ PEQUAMING } \\
\hline UPLAND vs LAKE & $\mathrm{P}=0.008$ \\
\hline TRANSITION vs LAKE & $\mathrm{P}=<0.001$ \\
\hline OPEN FEN vs LAKE & $\mathrm{P}=<0.001$ \\
\hline \multicolumn{1}{|c|}{ LIGHTFOOT BAY } \\
\hline UPLAND vs LAKE BETE GRISE \\
\hline TRANSITION vs LAKE & $\mathrm{P}=<0.001$ \\
\hline OPEN FEN vs LAKE & $\mathrm{P}=0.001$ \\
\hline \multicolumn{2}{|c|}{$\mathrm{P}=<0.001$} \\
\hline UPLAND vs LAKE & $\mathrm{P}=0.003$ \\
\hline DUNE AND SWALE vs LAKE & $\mathrm{P}=0.003$ \\
\hline
\end{tabular}


Table 3.

One-way ANOVA of specific conductance for each vegetation zone compared to lake water

\begin{tabular}{|l|c|}
\hline Comparison & $\mathbf{P}<\mathbf{0 . 0 5}$ \\
\hline PQ lake vs PQ open fen & Yes \\
\hline PQ lake vs PQ transition & Yes \\
\hline PQ lake vs PQ upland & No \\
\hline PQ upland vs PQ open fen & Yes \\
\hline PQ upland vs PQ transition & No \\
\hline PQ transition vs PQ open fen & No \\
\hline & \\
\hline LB upland vs LB open fen & Yes \\
\hline LB upland vs LB transition & No \\
\hline LB upland vs LB lake & No \\
\hline LB lake vs LB open fen & Yes \\
\hline LB lake vs LB transition & No \\
\hline LB transition vs LB open fen & Yes \\
\hline & \\
\hline BG lake vs BG upland & Yes \\
\hline BG lake vs BG dune\&swale & No \\
\hline BG dune\&swale vs BG upland & No \\
\hline
\end{tabular}




\section{Appendix}

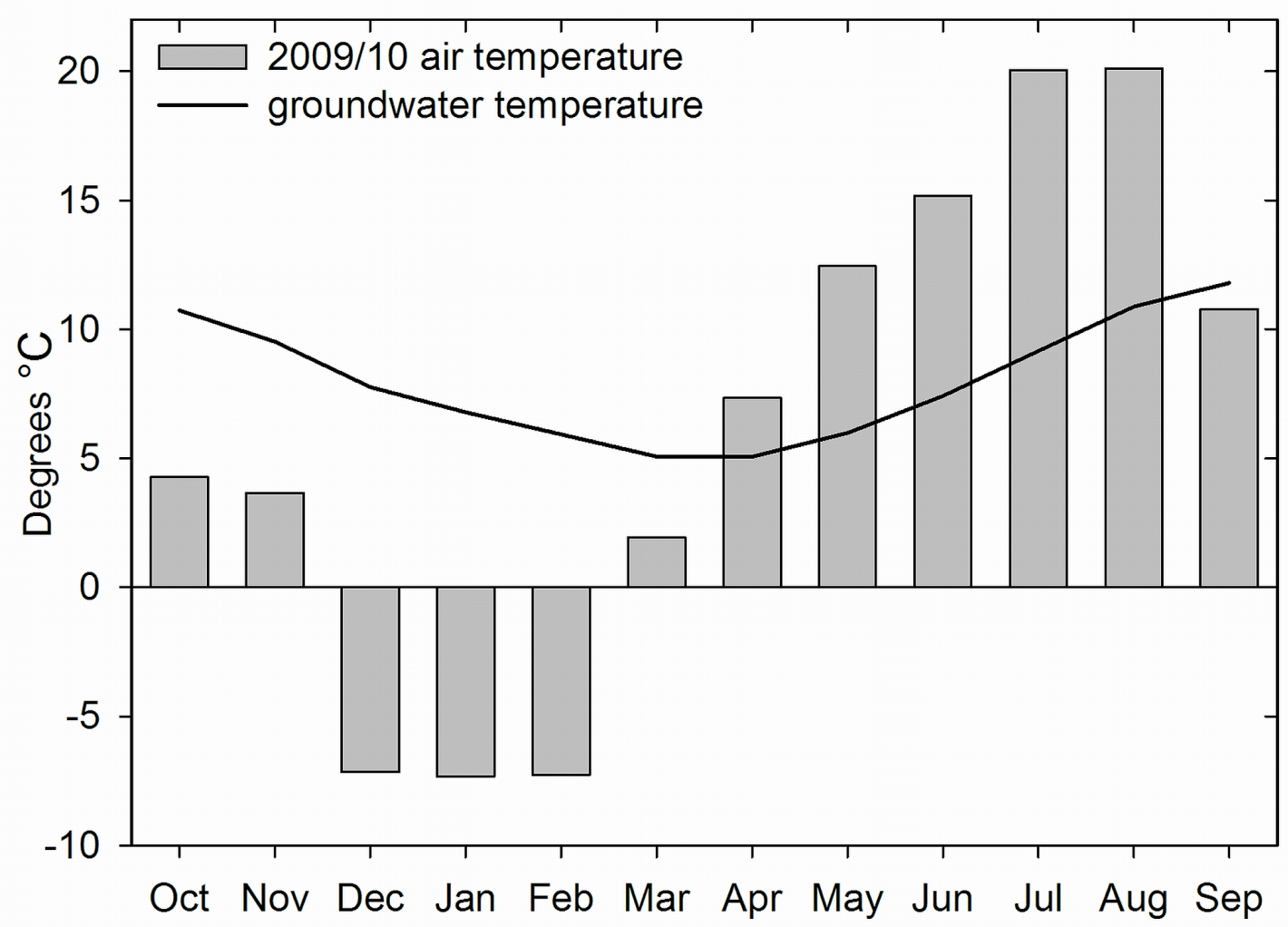

Figure 14. Monthly air and groundwater temperatures at Pequaming 
Table 4.

Seasonal summary table of specific conductance $(\mu \mathrm{S} / \mathrm{cm})$ at Pequaming

\begin{tabular}{|c|c|c|c|c|c|c|c|c|c|c|}
\hline Date & $\begin{array}{c}\text { May } \\
\mathbf{2 8}\end{array}$ & $\begin{array}{c}\text { Jun } \\
\mathbf{1 7}\end{array}$ & $\begin{array}{c}\text { Jun } \\
\mathbf{2 3}\end{array}$ & Jul 5 & Jul 21 & Aug 7 & $\begin{array}{c}\text { Aug } \\
\mathbf{2 7}\end{array}$ & $\begin{array}{c}\text { Sep } \\
\mathbf{1 2}\end{array}$ & $\begin{array}{c}\text { Sep } \\
\mathbf{3 0}\end{array}$ & Oct 26 \\
\hline $\begin{array}{c}\text { Up- } \\
\text { land }\end{array}$ & 77.90 & 81.83 & 113.37 & 102.27 & 111.03 & 109.07 & 95.37 & 80.33 & 79.43 & 79.17 \\
\hline $\begin{array}{c}\text { Tran- } \\
\text { sition }\end{array}$ & 70.47 & 65.40 & 70.40 & 67.50 & 71.60 & 77.13 & 70.90 & 64.37 & 64.77 & 64.47 \\
\hline $\begin{array}{c}\text { Open } \\
\text { fen }\end{array}$ & 54.93 & 62.77 & 61.27 & 57.83 & 54.53 & 56.80 & 55.47 & 50.33 & 50.20 & 49.13 \\
\hline
\end{tabular}

Table 5.

Seasonal summary table of specific conductance $(\mu \mathrm{S} / \mathrm{cm})$ at Lightfoot Bay

\begin{tabular}{|c|c|c|c|c|c|c|c|c|c|c|}
\hline Date & Jun 1 & $\begin{array}{c}\text { Jun } \\
\mathbf{1 7}\end{array}$ & $\begin{array}{c}\text { Jun } \\
\mathbf{2 3}\end{array}$ & Jul 5 & Jul 21 & Aug 7 & $\begin{array}{c}\text { Aug } \\
\mathbf{2 7}\end{array}$ & $\begin{array}{c}\text { Sep } \\
\mathbf{1 2}\end{array}$ & Oct 3 & $\begin{array}{c}\text { Oct } \\
\mathbf{2 6}\end{array}$ \\
\hline Upland & $\begin{array}{c}128.0 \\
7\end{array}$ & 73.63 & 83.37 & $\begin{array}{c}87.1 \\
3\end{array}$ & $\begin{array}{c}105.6 \\
0\end{array}$ & $\begin{array}{c}123.1 \\
3\end{array}$ & 96.37 & 84.80 & 88.17 & 81.07 \\
\hline $\begin{array}{c}\text { Tran- } \\
\text { sition }\end{array}$ & 75.00 & 77.83 & 80.13 & $\begin{array}{c}74.6 \\
3\end{array}$ & 73.63 & 98.73 & 82.23 & 79.90 & 96.40 & 71.00 \\
\hline $\begin{array}{c}\text { Open } \\
\text { fen }\end{array}$ & 52.27 & 55.57 & 58.87 & 60.4 & 62.93 & 64.70 & 63.90 & 59.33 & 59.80 & 63.70 \\
\hline
\end{tabular}


Table 6.

Seasonal summary table of specific conductance $(\mu \mathrm{S} / \mathrm{cm})$ at Bete Grise

\begin{tabular}{|c|c|c|c|c|c|c|c|c|c|c|}
\hline Date & May & Jun & Jun & Jul 6 & Jul 20 & Aug 6 & $\begin{array}{c}\text { Aug } \\
\mathbf{2 6}\end{array}$ & Sep 10 & Oct 3 & $\begin{array}{c}\text { Oct } \\
\mathbf{2 7}\end{array}$ \\
\hline $\begin{array}{c}\text { Up- } \\
\text { land }\end{array}$ & 38.17 & 34.53 & 53.93 & 59.83 & 61.40 & 84.43 & 84.37 & 67.80 & 67.10 & 47.83 \\
\hline $\begin{array}{c}\text { Dune } \\
\text { and } \\
\text { swale }\end{array}$ & 80.00 & 71.13 & 72.05 & 79.17 & 79.30 & 83.40 & 75.85 & 70.78 & 80.48 & 77.30 \\
\hline
\end{tabular}

Table 7.

Seasonal summary table of $\mathrm{pH}$ at Pequaming

\begin{tabular}{|c|c|c|c|c|c|c|c|c|c|c|}
\hline Date & $\begin{array}{c}\text { May } \\
\mathbf{2 8}\end{array}$ & $\begin{array}{c}\text { Jun } \\
\mathbf{1 7}\end{array}$ & $\begin{array}{c}\text { Jun } \\
\mathbf{2 3}\end{array}$ & Jul 5 & Jul 21 & Aug 7 & Aug 27 & Sep 12 & $\begin{array}{c}\text { Sep } \\
\mathbf{3 0}\end{array}$ & $\begin{array}{c}\text { Oct } \\
\mathbf{2 6}\end{array}$ \\
\hline $\begin{array}{c}\text { Up- } \\
\text { land }\end{array}$ & 5.97 & 5.96 & 6.09 & 5.90 & 5.88 & 6.03 & 6.11 & 5.76 & 5.75 & 5.96 \\
\hline $\begin{array}{c}\text { Tran- } \\
\text { sition }\end{array}$ & 5.57 & 5.77 & 5.70 & 5.69 & 5.70 & 5.76 & 5.75 & 5.63 & 5.67 & 5.80 \\
\hline $\begin{array}{c}\text { Open } \\
\text { fen }\end{array}$ & 5.02 & 5.37 & 5.38 & 5.45 & 5.41 & 5.29 & 5.16 & 5.35 & 5.29 & 5.35 \\
\hline
\end{tabular}


Table 8.

Seasonal summary table of $\mathrm{pH}$ at Lightfoot Bay

\begin{tabular}{|c|c|c|c|c|c|c|c|c|c|c|}
\hline Date & Jun 1 & $\begin{array}{c}\text { Jun } \\
\mathbf{1 7}\end{array}$ & $\begin{array}{c}\text { Jun } \\
\mathbf{2 3}\end{array}$ & $\mathbf{J u l} \mathbf{5}$ & $\mathbf{J u l} \mathbf{2 1}$ & $\mathbf{A u g} 7$ & $\begin{array}{c}\text { Aug } \\
\mathbf{2 7}\end{array}$ & $\begin{array}{c}\text { Sep } \\
\mathbf{1 2}\end{array}$ & Oct 3 & $\begin{array}{c}\text { Oct } \\
\mathbf{2 6}\end{array}$ \\
\hline Upland & 5.87 & 5.65 & 5.85 & 6.06 & 6.12 & 5.90 & 5.93 & 6.11 & 5.93 & 5.92 \\
\hline $\begin{array}{c}\text { Tran- } \\
\text { sition }\end{array}$ & 5.26 & 5.49 & 5.45 & 5.59 & 5.50 & 5.25 & 5.50 & 5.45 & 5.24 & 5.43 \\
\hline $\begin{array}{c}\text { Open } \\
\text { fen }\end{array}$ & 5.04 & 5.51 & 5.35 & 5.57 & 5.48 & 5.57 & 5.57 & 5.47 & 5.30 & 5.47 \\
\hline
\end{tabular}

Table 9.

Seasonal summary table of $\mathrm{pH}$ at Bete Grise

\begin{tabular}{|c|c|c|c|c|c|c|c|c|c|c|}
\hline Date & $\begin{array}{c}\text { May } \\
\mathbf{2 8}\end{array}$ & Jun 14 & $\begin{array}{c}\text { Jun } \\
\mathbf{2 4}\end{array}$ & Jul 6 & Jul 20 & Aug 6 & $\begin{array}{c}\text { Aug } \\
\mathbf{2 6}\end{array}$ & Sep 10 & Oct 3 & Oct 27 \\
\hline Upland & 4.86 & 4.64 & 4.68 & 5.07 & 5.82 & 5.96 & 5.94 & 5.49 & 4.38 & 4.49 \\
\hline $\begin{array}{c}\text { Dune } \\
\text { and } \\
\text { swale }\end{array}$ & 5.49 & 5.53 & 5.09 & 5.34 & 5.52 & 5.43 & 5.22 & 5.37 & 5.03 & 4.88 \\
\hline
\end{tabular}


Table 10.

Mean daily temperatures and monthly accumulated precipitation from 1889 to 2009 and for 2010

\begin{tabular}{|r|c|c|c|c|}
\hline & \multicolumn{2}{|c|}{ Average from 1889 to 2009 } & \multicolumn{2}{c|}{$\mathbf{2 0 1 0}$} \\
\cline { 2 - 5 } & Precipitation $(\mathrm{mm})$ & $\begin{array}{c}\text { Average daily temp } \\
{ }^{\circ} \mathrm{C}\end{array}$ & $\begin{array}{c}\text { Precipitation }(\mathrm{mm}) \\
\begin{array}{c}\text { Average daily } \\
\text { temp }{ }^{\circ} \mathrm{C}\end{array}\end{array}$ \\
\hline January & 80.37 & -9.58 & 12.45 & -7.33 \\
\hline February & 47.00 & -9.36 & 0.51 & -7.28 \\
\hline March & 46.96 & -4.42 & 5.84 & 1.94 \\
\hline April & 50.69 & 3.03 & 45.97 & 12.44 \\
\hline May & 75.39 & 9.80 & 24.13 & 15.17 \\
\hline June & 77.67 & 15.27 & 125.73 & 20.06 \\
\hline July & 74.32 & 18.34 & 43.43 & 20.11 \\
\hline August & 73.34 & 17.49 & 96.27 & 10.78 \\
\hline September & 91.19 & 13.09 & 178.56 & 8.17 \\
\hline October & 72.59 & 7.02 & 47.75 & 0.56 \\
\hline November & 68.84 & -0.48 & 56.13 & -6.72 \\
\hline $\begin{array}{r}\text { December } \\
\text { SuM }\end{array}$ & 75.56 & -6.53 & 12.95 & $\mathbf{6 4 9 . 7 3}$ \\
\hline precipitation
\end{tabular}


Table 11.

Lake Superior levels of 2010 and long-term recorded monthly minimum and maximum levels at Marquette, MI

\begin{tabular}{|c|c|c|c|c|}
\hline & \multicolumn{4}{|c|}{ meters above sea level } \\
\hline & 2010 & 1918-2009 & MIN & MAX \\
\hline January & 183.24 & 183.33 & 182.83 & 183.7 \\
\hline February & 183.17 & 183.27 & 182.76 & 183.63 \\
\hline March & 183.10 & 183.24 & 182.74 & 183.61 \\
\hline April & 183.09 & 183.26 & 182.72 & 183.68 \\
\hline May & 183.09 & 183.37 & 182.76 & 183.74 \\
\hline June & 183.14 & 183.45 & 182.85 & 183.76 \\
\hline July & 183.20 & 183.51 & 182.96 & 183.82 \\
\hline August & 183.22 & 183.54 & 183.01 & 183.86 \\
\hline September & 183.24 & 183.54 & 183.02 & 183.86 \\
\hline October & 183.20 & 183.51 & 183.1 & 183.91 \\
\hline November & 183.15 & 183.47 & 183.01 & 183.89 \\
\hline December & 183.10 & 183.41 & 182.92 & 183.81 \\
\hline $\mathrm{AVG}$ & 183.16 & 183.41 & & \\
\hline
\end{tabular}


Table 12.

Pooled seasonal average specific conductance with respect to distance from upland at Lightfoot Bay and Pequaming

\begin{tabular}{|c|c|c|c|c|c|c|c|}
\hline & well & distance & $\mu \mathrm{S} / \mathrm{cm}$ & & well & distance & $\mu \mathrm{S} / \mathrm{cm}$ \\
\hline \multirow{7}{*}{ 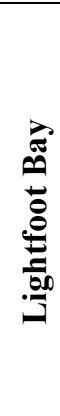 } & 1 & 270 & 60.8 & \multirow{7}{*}{ 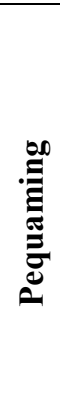 } & 1 & 470 & 41.6 \\
\hline & 2 & 200 & 58.5 & & 2 & 340 & 64.3 \\
\hline & 3 & 120 & 61.1 & & 3 & 230 & 60.1 \\
\hline & 4 & 87 & 68.7 & & 4 & 150 & 54.4 \\
\hline & 5 & 50 & 72.1 & & 5 & 110 & 60.2 \\
\hline & 6 & 25 & 105 & & 6 & 66 & 91.5 \\
\hline & UPLAND & 0 & 95.1 & & UPLAND & 0 & 93.5 \\
\hline
\end{tabular}

Table 13.

Air and groundwater temperatures at Pequaming

\begin{tabular}{|c|c|c|}
\hline & $\begin{array}{c}\text { Air temperatures } \\
2009 / 10^{\circ} \mathrm{C}\end{array}$ & $\begin{array}{c}\text { Groundwater } \\
\text { temperature }{ }^{\circ} \mathrm{C}\end{array}$ \\
\hline Oct & 4.28 & 10.73 \\
\hline Nov & 3.66 & 9.53 \\
\hline Dec & -7.16 & 7.76 \\
\hline Jan & -7.33 & 6.79 \\
\hline Feb & -7.28 & 5.93 \\
\hline Mar & 1.94 & 5.07 \\
\hline Apr & 7.33 & 5.06 \\
\hline May & 12.44 & 5.98 \\
\hline Jun & 15.17 & 7.42 \\
\hline Jul & 20.06 & 9.17 \\
\hline Aug & 20.11 & 10.87 \\
\hline Sep & 10.78 & 11.80 \\
\hline
\end{tabular}


Table 14.

Ground elevation and peat depth survey, Lightfoot Bay

\begin{tabular}{|c|c|c|c|c|c|c|}
\hline & & & list (m) & elevation & subsurface & \\
\hline LB8 & 46.90001 & -88.178196 & $\mathbf{0}$ & 183.657 & 183.403 & upland \\
\hline 203 & 46.90011 & -88.178269 & 12 & 183.367 & 182.884 & \multirow{7}{*}{ 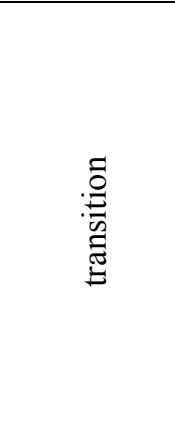 } \\
\hline LB6 & 46.90024 & -88.178206 & 25 & 183.521 & 182.860 & \\
\hline 205 & 46.90033 & -88.178207 & 36 & 183.571 & 182.784 & \\
\hline LB5 & 46.90046 & -88.178222 & 50 & 183.539 & 182.841 & \\
\hline 207 & 46.90056 & -88.17826 & 61 & 183.445 & 181.946 & \\
\hline 208 & 46.90069 & -88.178348 & 76 & 183.499 & 182.178 & \\
\hline LB4 & 46.90079 & -88.178288 & 87 & 183.595 & 182.630 & \\
\hline 210 & 46.9009 & -88.178331 & 100 & 183.423 & 182.051 & \multirow{10}{*}{ 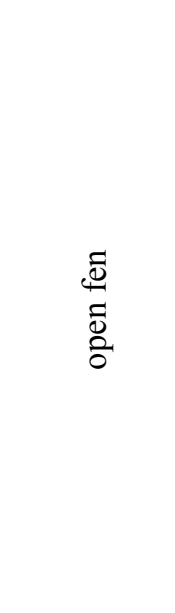 } \\
\hline LB3 & 46.90111 & -88.178377 & 120 & 183.394 & 181.692 & \\
\hline 212 & 46.90128 & -88.178431 & 140 & 183.324 & 181.063 & \\
\hline 213 & 46.90152 & -88.178477 & 170 & 183.271 & 181.595 & \\
\hline LB2 & 46.9018 & -88.178559 & 200 & 183.277 & 179.924 & \\
\hline 215 & 46.90197 & -88.178614 & 220 & 183.253 & 180.154 & \\
\hline 217 & 46.90219 & -88.178694 & 250 & 183.271 & 181.036 & \\
\hline LB1 & 46.90241 & -88.178811 & 270 & 183.324 & 182.003 & \\
\hline 219 & 46.90254 & -88.178875 & 290 & 183.229 & 182.061 & \\
\hline 220 & 46.90281 & -88.179017 & 320 & 183.226 & 181.727 & \\
\hline 221 & 46.90302 & -88.179206 & 340 & 183.341 & 183.036 & sand barrier \\
\hline LAKE & 46.90475 & -88.182656 & $\mathbf{6 3 0}$ & 183.158 & 183.158 & $\begin{array}{c}\text { Lake } \\
\text { Superior }\end{array}$ \\
\hline
\end{tabular}


Table 15.

Ground elevation and peat depth survey, Pequaming

\begin{tabular}{|c|c|c|c|c|c|c|}
\hline & & & dist (m) & elevation & subsurface & \\
\hline PQ8 & 46.84942 & -88.3709 & $\mathbf{0}$ & 184.219 & 183.508 & upland \\
\hline 303 & 46.84965 & -88.3715 & 57 & 183.925 & 183.442 & \multirow{7}{*}{ 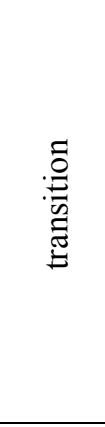 } \\
\hline PQ6 & 46.84966 & -88.3716 & 66 & 183.880 & 183.449 & \\
\hline 305 & 46.84985 & -88.3716 & 72 & 183.852 & 183.141 & \\
\hline PQ5 & 46.84989 & -88.3721 & 110 & 183.882 & 182.790 & \\
\hline 307 & 46.84998 & -88.3723 & 130 & 183.907 & 183.069 & \\
\hline PQ4 & 46.85012 & -88.3725 & 150 & 183.779 & 182.839 & \\
\hline 309 & 46.85028 & -88.3729 & 190 & 183.798 & 182.757 & \\
\hline PQ3 & 46.8506 & -88.3733 & 230 & 183.751 & 182.456 & \multirow{7}{*}{ 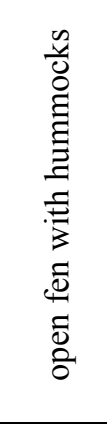 } \\
\hline 311 & 46.85082 & -88.3737 & 270 & 183.733 & 182.692 & \\
\hline 312 & 46.85104 & -88.3742 & 310 & 183.723 & 182.682 & \\
\hline PQ2 & 46.85119 & -88.3744 & 340 & 183.761 & 182.593 & \\
\hline 314 & 46.85159 & -88.3751 & 400 & 183.681 & 182.513 & \\
\hline 315 & 46.85196 & -88.3755 & 450 & 183.850 & 182.809 & \\
\hline PQ1 & 46.85209 & -88.3756 & 470 & 183.708 & 182.717 & \\
\hline 317 & 46.85242 & -88.376 & 510 & 183.676 & 180.882 & \multirow{12}{*}{ 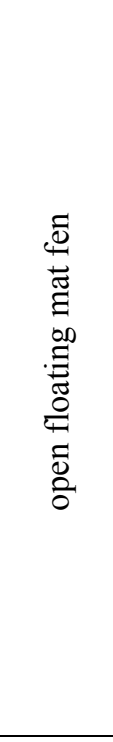 } \\
\hline 318 & 46.8527 & -88.3765 & 560 & 183.654 & 181.089 & \\
\hline 319 & 46.85308 & -88.3772 & 630 & 183.591 & 181.229 & \\
\hline 321 & 46.85328 & -88.3775 & 660 & 184.074 & 180.975 & \\
\hline 323 & 46.85329 & -88.3775 & 670 & 183.750 & 181.261 & \\
\hline 324 & 46.85349 & -88.3778 & 700 & 183.699 & 181.235 & \\
\hline 325 & 46.8538 & -88.3783 & 750 & 183.963 & 181.169 & \\
\hline 326 & 46.85426 & -88.3792 & 830 & 183.673 & 181.184 & \\
\hline 327 & 46.85474 & -88.3802 & 930 & 183.593 & 181.104 & \\
\hline 328 & 46.85499 & -88.3808 & 980 & 183.679 & 181.215 & \\
\hline 329 & 46.85502 & -88.3808 & 985 & 183.767 & 180.668 & \\
\hline 330 & 46.85537 & -88.3818 & 1060 & 183.613 & 182.114 & \\
\hline 331 & 46.85567 & -88.3826 & 1130 & 183.610 & 182.391 & \multirow{4}{*}{ 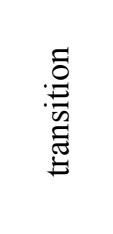 } \\
\hline 333 & 46.85608 & -88.383 & 1190 & 183.573 & 182.760 & \\
\hline 334 & 46.85639 & -88.3835 & 1230 & 183.679 & 182.434 & \\
\hline 335 & 46.85653 & -88.3836 & 1250 & 183.581 & 182.692 & \\
\hline
\end{tabular}


Table 16.

Ground elevation and peat depth survey, Bete Grise

\begin{tabular}{|c|c|c|c|c|c|c|}
\hline & & & dist (m) & elevation & \multicolumn{2}{|c|}{ subsurface } \\
\hline BG2 & 47.360769 & -87.968649 & $\mathbf{0}$ & 187.252 & 187.100 & upland \\
\hline 405 & 47.361017 & -87.968101 & 49 & 187.383 & 186.519 & \multirow{2}{*}{ treed fen } \\
\hline 407 & 47.361117 & -87.967717 & 80 & 187.399 & 186.713 & \\
\hline BG5 & 47.361436 & -87.966789 & 160 & 185.994 & 185.283 & \multirow{9}{*}{ 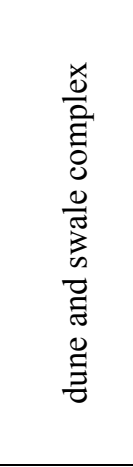 } \\
\hline 410 & 47.361576 & -87.966667 & 170 & 186.458 & 186.433 & \\
\hline 411 & 47.361825 & -87.966511 & 200 & 185.602 & 184.891 & \\
\hline 412 & 47.361919 & -87.966382 & 210 & 186.352 & 186.276 & \\
\hline 413 & 47.362053 & -87.966189 & 230 & 185.312 & 185.007 & \\
\hline 414 & 47.362183 & -87.965809 & 270 & 185.216 & 184.530 & \\
\hline 416 & 47.362592 & -87.9657 & 300 & 185.114 & 184.784 & \\
\hline 417 & 47.363153 & -87.965719 & 350 & 184.994 & 184.308 & \\
\hline BG7 & 47.363361 & -87.96568 & 370 & 185.054 & 184.140 & \\
\hline 419 & 47.363692 & -87.965639 & 400 & 185.033 & 184.779 & \multirow{2}{*}{ open fen } \\
\hline 420 & 47.363928 & -87.965567 & 420 & 184.959 & 184.349 & \\
\hline 421 & 47.364022 & -87.965318 & 440 & 185.371 & 185.269 & dune \\
\hline BG8 & 47.364864 & -87.965597 & 510 & 184.753 & 184.651 & swale \\
\hline 423 & 47.364933 & -87.965536 & 520 & 185.319 & 185.319 & \multirow{2}{*}{ dune } \\
\hline BG9 & 47.365347 & -87.964887 & 580 & 185.438 & 185.438 & \\
\hline LAKE & 47.365342 & -87.964314 & 600 & 183.6 & 183.6 & \\
\hline
\end{tabular}

Table 17.

Specific conductance (SE) all season Pequaming open fen

\begin{tabular}{|c|c|c|c|c|c|c|c|}
\hline \multicolumn{6}{|c|}{$\mu \mathrm{S}$ open fen } & \multirow[b]{2}{*}{$\begin{array}{l}\text { AVG } \\
\text { open }\end{array}$} & \multirow[b]{2}{*}{$\begin{array}{c}\text { SE } \\
\text { open }\end{array}$} \\
\hline Date & well 1 & well 2 & well 3 & average & SE & & \\
\hline 28-May & 41.5 & 56.6 & 66.7 & 54.93 & 7.32 & 55.33 & 2.18 \\
\hline 17-Jun & 44.1 & 68.5 & 75.7 & 62.77 & 9.56 & & \\
\hline 23-Jun & 37.2 & 73.8 & 72.8 & 61.27 & 12.04 & & \\
\hline 5-Jul & 40.9 & 72.3 & 60.3 & 57.83 & 9.15 & & \\
\hline 21-Jul & 38.4 & 67.6 & 57.6 & 54.53 & 8.57 & & \\
\hline 7-Aug & 43.9 & 68.4 & 58.1 & 56.80 & 7.10 & & \\
\hline 27-Aug & 44.5 & 67.7 & 54.2 & 55.47 & 6.73 & & \\
\hline 12-Sep & 41.3 & 58.4 & 51.3 & 50.33 & 4.96 & & \\
\hline 30-Sep & 42.9 & 55.2 & 52.5 & 50.20 & 3.73 & & \\
\hline 26-Oct & 41.3 & 54.5 & 51.6 & 49.13 & 4.01 & & \\
\hline
\end{tabular}


Table 18.

Specific conductance (SE) all season Pequaming transition zone

\begin{tabular}{c|ccc|cccc}
\multicolumn{8}{c}{$\boldsymbol{\mu S}$ transition } \\
\hline Date & well 4 & well 5 & well 6 & average & SE & $\begin{array}{c}\text { AVG } \\
\text { trans }\end{array}$ & $\begin{array}{c}\text { SE } \\
\text { trans }\end{array}$ \\
\hline 28-May & 56.4 & 47.2 & 107.8 & $\mathbf{7 0 . 4 7}$ & 18.86 & 68.7 & 3.27 \\
17-Jun & 50.2 & 60.9 & 85.1 & $\mathbf{6 5 . 4 0}$ & 10.32 & & \\
23-Jun & 54.7 & 60.1 & 96.4 & $\mathbf{7 0 . 4 0}$ & 13.09 & & \\
5-Jul & 48.8 & 64.4 & 89.3 & $\mathbf{6 7 . 5 0}$ & 11.79 & & \\
21-Jul & 54 & 60.7 & 100.1 & $\mathbf{7 1 . 6 0}$ & 14.38 & & \\
7-Aug & 57.5 & 69.8 & 104.1 & $\mathbf{7 7 . 1 3}$ & 13.94 & & \\
27-Aug & 58.1 & 63.5 & 91.1 & $\mathbf{7 0 . 9 0}$ & 10.22 & & \\
12-Sep & 56.8 & 60 & 76.3 & $\mathbf{6 4 . 3 7}$ & 6.04 & & \\
30-Sep & 56.1 & 56.3 & 81.9 & $\mathbf{6 4 . 7 7}$ & 8.57 & & \\
26-Oct & 51.7 & 58.8 & 82.9 & $\mathbf{6 4 . 4 7}$ & 9.44 & &
\end{tabular}

Table 19.

Specific conductance (SE) all season Pequaming upland and lake water

\begin{tabular}{|c|c|c|c|c|c|c|c|c|c|}
\hline \multicolumn{3}{|c|}{$\mu S$ upland } & \multirow[b]{2}{*}{ AVG } & \multirow[b]{2}{*}{ SE } & \multirow[b]{2}{*}{$\begin{array}{c}\text { AVG } \\
\text { UP }\end{array}$} & \multirow[b]{2}{*}{$\begin{array}{l}\text { SE } \\
\text { UP }\end{array}$} & \multicolumn{3}{|c|}{ Lake water } \\
\hline well 7 & well 8 & well 9 & & & & & $\mu \mathrm{S}$ & average & SE \\
\hline 69.4 & & 86.4 & 77.90 & 8.50 & 93.50 & 4.83 & 90.3 & 91.34 & 0.679 \\
\hline 49.2 & 89.2 & 107 & 81.83 & 17.12 & & & 90.4 & & \\
\hline 79 & 154.9 & 106 & 113.37 & 22.20 & & & 87.8 & & \\
\hline 70.3 & 132.7 & 104 & 102.27 & 18.03 & & & 88.8 & & \\
\hline 72.6 & 144.8 & 116 & 111.03 & 20.97 & & & 94 & & \\
\hline 72.1 & 138.1 & 117 & 109.07 & 19.46 & & & 94.5 & & \\
\hline 72.2 & 111.6 & 102 & 95.37 & 11.89 & & & 92.7 & & \\
\hline 82.3 & 73.5 & 85.2 & 80.33 & 3.52 & & & 91.8 & & \\
\hline 73.1 & 79.2 & 86 & 79.43 & 3.73 & & & 92.4 & & \\
\hline 66.6 & 74.4 & 96.5 & 79.17 & 8.95 & & & 90.7 & & \\
\hline
\end{tabular}


Table 20.

Specific conductance (SE) all season Lightfoot Bay open fen

\begin{tabular}{c|ccc|cccc}
\hline \multicolumn{7}{|c}{$\boldsymbol{\mu S}$ open fen } \\
Date & well 1 & well 2 & well 3 & average & SE & $\begin{array}{c}\text { AVG } \\
\text { open }\end{array}$ & SE open \\
\hline 1-Jun & 41.2 & 58.1 & 57.5 & $\mathbf{5 2 . 2 7}$ & 5.54 & 60.15 & 1.24 \\
17-Jun & 58.2 & 56.9 & 51.6 & $\mathbf{5 5 . 5 7}$ & 2.02 & & \\
23-Jun & 63.3 & 56.4 & 56.9 & $\mathbf{5 8 . 8 7}$ & 2.22 & & \\
5-Jul & 66.2 & 57 & 58 & $\mathbf{6 0 . 4 0}$ & 2.91 & & \\
21-Jul & 68.2 & 61.1 & 59.5 & $\mathbf{6 2 . 9 3}$ & 2.67 & & \\
7-Aug & 72.4 & 60.1 & 61.6 & $\mathbf{6 4 . 7 0}$ & 3.87 & & \\
27-Aug & 69.4 & 62 & 60.3 & $\mathbf{6 3 . 9 0}$ & 2.79 & & \\
12-Sep & 60 & 59.8 & 58.2 & $\mathbf{5 9 . 3 3}$ & 0.57 & & \\
3-Oct & 50 & 56.6 & 72.8 & $\mathbf{5 9 . 8 0}$ & 6.77 & & \\
26-Oct & 59.3 & 57.4 & 74.4 & $\mathbf{6 3 . 7 0}$ & 5.38 & &
\end{tabular}

Table 21.

Specific conductance (SE) all season Lightfoot Bay transition zone

\begin{tabular}{c|ccc|cccc}
\multicolumn{7}{c}{$\boldsymbol{\mu S}$ transition } \\
\hline Date & well 4 & well 5 & well 6 & average & SE & $\begin{array}{c}\text { AVG } \\
\text { trans }\end{array}$ & $\begin{array}{c}\text { SE } \\
\text { trans }\end{array}$ \\
\hline 1-Jun & 72.5 & 77.5 & & $\mathbf{7 5 . 0 0}$ & 56.75 & 81.16 & 4.07 \\
17-Jun & 60.4 & 52.5 & 120.6 & $\mathbf{7 7 . 8 3}$ & 21.50 & & \\
23-Jun & 66.8 & 65.6 & 108 & $\mathbf{8 0 . 1 3}$ & 13.94 & & \\
5-Jul & 63.4 & 68.9 & 91.6 & $\mathbf{7 4 . 6 3}$ & 8.63 & & \\
21-Jul & 58.9 & 63.2 & 98.8 & $\mathbf{7 3 . 6 3}$ & 12.64 & & \\
7-Aug & 67 & 76.3 & 152.9 & $\mathbf{9 8 . 7 3}$ & 27.22 & & \\
27-Aug & 67.7 & 72.5 & 106.5 & $\mathbf{8 2 . 2 3}$ & 12.21 & & \\
12-Sep & 70.3 & 80 & 89.4 & $\mathbf{7 9 . 9 0}$ & 5.51 & & \\
3-Oct & 90.2 & 91.2 & 107.8 & $\mathbf{9 6 . 4 0}$ & 5.71 & & \\
26-Oct & 69.4 & 73.6 & 70 & $\mathbf{7 1 . 0 0}$ & 1.31 & &
\end{tabular}


Table 22.

Specific conductance (SE) all season Lightfoot Bay upland

\begin{tabular}{c|ccc|cccc}
\multicolumn{7}{c}{$\boldsymbol{M S}$ upland } \\
\hline Date & well 7 & well 8 & well 9 & average & SE & $\begin{array}{c}\text { AVG } \\
\text { upland }\end{array}$ & $\begin{array}{c}\text { SE } \\
\text { upland }\end{array}$ \\
\hline 1-Jun & 156.6 & 111.5 & 116 & $\mathbf{1 2 8 . 0 7}$ & 14.33 & 95.13 & 4.95 \\
17-Jun & 61.9 & 62.4 & 96.6 & $\mathbf{7 3 . 6 3}$ & 11.48 & & \\
23-Jun & 73.7 & 69.1 & 107 & $\mathbf{8 3 . 3 7}$ & 12.04 & & \\
5-Jul & 93.1 & 71.8 & 96.5 & $\mathbf{8 7 . 1 3}$ & 7.73 & & \\
21-Jul & 120.7 & 82.9 & 113 & $\mathbf{1 0 5 . 6 0}$ & 11.55 & & \\
7-Aug & 173.4 & 79.6 & 116 & $\mathbf{1 2 3 . 1 3}$ & 27.29 & & \\
27-Aug & 106 & 73.8 & 109 & $\mathbf{9 6 . 3 7}$ & 11.32 & & \\
12-Sep & 85.1 & 70.5 & 98.8 & $\mathbf{8 4 . 8 0}$ & 8.17 & & \\
3-Oct & 90.1 & 65.5 & 109 & $\mathbf{8 8 . 1 7}$ & 12.57 & & \\
26-Oct & 59.3 & 69.5 & 114 & $\mathbf{8 1 . 0 7}$ & 16.92 & &
\end{tabular}

Table 23.

Specific conductance (SE) all season Bete Grise upland

\begin{tabular}{c|ccc|cccc}
\multicolumn{7}{c}{$\boldsymbol{\mu S}$ upland } \\
\hline Date & well 1 & well 2 & well 3 & average & SE & $\begin{array}{c}\text { AVG } \\
\text { upland }\end{array}$ & $\begin{array}{c}\text { SE } \\
\text { upland }\end{array}$ \\
\hline 28-May & 42.3 & 34.2 & 38 & $\mathbf{3 8 . 1 7}$ & 2.34 & 59.94 & 4.04 \\
14-Jun & 31.5 & 33.6 & 38.5 & $\mathbf{3 4 . 5 3}$ & 2.074 & & \\
24-Jun & 48 & 55 & 58.8 & $\mathbf{5 3 . 9 3}$ & 3.163 & & \\
6-Jul & 53.5 & 44.4 & 81.6 & $\mathbf{5 9 . 8 3}$ & 11.196 & & \\
20-Jul & 42.6 & 44 & 97.6 & $\mathbf{6 1 . 4 0}$ & 18.105 & & \\
6-Aug & 82.8 & 58.6 & 111.9 & $\mathbf{8 4 . 4 3}$ & 15.408 & & \\
26-Aug & 74.9 & 67.3 & 110.9 & $\mathbf{8 4 . 3 7}$ & 13.447 & & \\
10-Sep & 62.9 & 58 & 82.5 & $\mathbf{6 7 . 8 0}$ & 7.485 & & \\
3-Oct & 58.8 & 77.1 & 65.4 & $\mathbf{6 7 . 1 0}$ & 5.351 & & \\
27-Oct & 40.8 & 36.5 & 66.2 & $\mathbf{4 7 . 8 3}$ & 9.267 & &
\end{tabular}


Table 24.

Specific conductance (SE) all season Bete Grise dune and swale complex $\mu \mathrm{S}$ dune and swale

\begin{tabular}{|c|c|c|c|c|c|c|c|c|c|c|}
\hline Date & well 4 & well 5 & well 6 & well 7 & well 8 & well 9 & AVG & SE & $\begin{array}{l}\text { AVG } \\
d \& s\end{array}$ & $\begin{array}{c}\text { SE } \\
\mathrm{d} \& \mathrm{~s}\end{array}$ \\
\hline 28-May & 47.5 & & 72 & 150.5 & & 50 & 80.00 & 24.14 & 76.95 & 5.87 \\
\hline 14-Jun & 59.1 & 61.1 & 76.2 & 145.3 & 40.6 & 44.5 & 71.13 & 15.72 & & \\
\hline 24-Jun & 52.7 & 56 & 88.2 & 149.2 & 33.7 & 52.5 & 72.05 & 17.03 & & \\
\hline 6-Jul & 52.7 & 51.8 & 108.1 & 179.3 & 31.6 & 51.5 & 79.17 & 22.61 & & \\
\hline 20-Jul & 60.6 & 47 & 126 & 157.3 & 40.3 & 44.6 & 79.30 & 20.32 & & \\
\hline 6-Aug & 54.3 & 39.8 & 142.1 & 182.2 & 40.8 & 41.2 & 83.40 & 25.53 & & \\
\hline 26-Aug & 50.1 & 46.6 & 125.8 & 139.7 & 43 & 49.9 & 75.85 & 18.11 & & \\
\hline 10-Sep & 52.4 & 75.3 & 141.6 & & 33.1 & 51.5 & 70.78 & 18.93 & & \\
\hline $3-\mathrm{Oct}$ & 50.2 & 118.3 & 95.1 & 148.1 & 30.9 & 40.3 & 80.48 & 19.33 & & \\
\hline 27-Oct & 67.6 & 86.9 & 85.6 & 156 & 22.8 & 44.9 & 77.30 & 18.68 & & \\
\hline
\end{tabular}


Table 25.

Vegetation survey Bete Grise upland

\begin{tabular}{|c|c|c|c|c|c|}
\hline \multicolumn{2}{|c|}{ BG upland 1x1m } & \multicolumn{4}{|c|}{ Cover class } \\
\hline Species name & Latin name & $\mathrm{NE}$ & $\mathrm{SE}$ & SW & NW \\
\hline Tawny Cotton-grass & Eriophorum virginicum & 5 & & & \\
\hline Tussock Cotton-grass & Eriophorum vaginatum & & & & 25 \\
\hline Tag alder & Alnus incana & 20 & & & \\
\hline Labrador tea & Ledum groenlandicum & 5 & & 7 & 50 \\
\hline Small cranberry & Vaccinium oxycoccus & 95 & & & \\
\hline Bog-laurel & Kalmia polifolia & 30 & & & \\
\hline \multicolumn{2}{|c|}{ Bryophytes } & 100 & 5 & 50 & 90 \\
\hline Canadian rush & Juncus canadensis & 5 & & & \\
\hline Three-leaf Solomon's-seal & Maianthemum trifolium & 20 & & & \\
\hline Cinnamon fern & Osmunda cinnamomea & 10 & & & \\
\hline Bluejoint & Calamagrostis canadensis & $<5$ & & & \\
\hline Boreal bog sedge & Carex magellanica & 7 & & 3 & \\
\hline Bunch berry & Cornus canadensis & & 1 & 3 & \\
\hline Canada mayflower & Maianthemum canadense & & 2 & 3 & \\
\hline Bracken fern & Pteridium aquilinum & & 20 & & \\
\hline Common lake sedge & Carex lacustris & & & & 15 \\
\hline Softleaf sedge & Carex disperma & & & & 2 \\
\hline Oval leaved bilberry & Vaccinium ovalifolium & & 40 & 25 & 10 \\
\hline Starflower & Borealis trientalis & & 1 & & \\
\hline Red maple & Acer rubrum & & 1 & & \\
\hline Balsam fir & Abies balsamea & & 1 & 1 & \\
\hline Leatherleaf & Chamaedaphne calyculata & & & & 50 \\
\hline Mountain Ash & Sorbus americana & & 1 & & \\
\hline \multicolumn{2}{|c|}{ Forest floor } & 60 & & 85 & \\
\hline Three-leaf goldthread & Coptis trifolia & & & 1 & \\
\hline Creeping snowberry & Gaultheria hispidula & & & 5 & \\
\hline Lowbush blueberry & Vaccinium angustifolium & & & 10 & 10 \\
\hline Northern Whitecedar & Thuja occidentalis & & & 20 & \\
\hline \multicolumn{2}{|c|}{$3 \times 3 \mathrm{~m}$} & $\mathrm{NE}$ & SE & SW & NW \\
\hline Labrador tea & Ledum groenlandicum & 75 & 3 & 15 & 25 \\
\hline Mountain Holly & Nemopanthus mucronata & $<5$ & & & \\
\hline Lowbush blueberry & Vaccinium angustifolium & 5 & & & \\
\hline Tag alder & Alnus incana & $<5$ & & & \\
\hline Northern white cedar & Thuja occidentalis & $<5$ & 20 & 40 & \\
\hline Black spruce & Picea mariana & $<5$ & & & 30 \\
\hline
\end{tabular}


Table 25 (continued)

\begin{tabular}{|l|l|c|c|c|c|}
\hline \multicolumn{2}{|c|}{ BG upland 1x1m } & \multicolumn{5}{c|}{ Cover class } \\
\hline \multicolumn{1}{|c|}{ Species name } & \multicolumn{1}{|c|}{ Latin name } & NE & SE & SW & NW \\
\hline Balsam fir & Abies balsamea & & 15 & 5 & \\
\hline Common bilberry & Vaccinium myrtillus & & 1 & & \\
\hline Serviceberry & Amelanchier & & & & \\
\hline Eastern Leatherwood & Dirca palustris & & & & \\
\hline Paper birch & Betula papyrifera & & \\
\hline
\end{tabular}


Table 26.

Vegetation survey, Bete Grise upland tree data

\begin{tabular}{|c|c|c|c|c|c|c|c|c|c|c|c|c|c|c|}
\hline \multicolumn{2}{|c|}{$\begin{array}{c}\text { Trees BG } \\
\text { Upland }\end{array}$} & \multicolumn{3}{|c|}{$\mathrm{NE}$} & \multicolumn{3}{|c|}{ SE } & \multicolumn{3}{|c|}{ SW } & \multicolumn{3}{|c|}{ NW } & \multirow[b]{2}{*}{$\begin{array}{c}\text { st per } \\
\text { ha }\end{array}$} \\
\hline $\begin{array}{l}\text { Species } \\
\text { name }\end{array}$ & $\begin{array}{l}\text { Latin } \\
\text { name }\end{array}$ & \# & $\overrightarrow{\underline{n}}$ & $\mathrm{H}$ & \# & $\overrightarrow{\bar{n}}$ & $\mathrm{H}$ & \# & $\overrightarrow{\widetilde{n}}$ & $\mathrm{H}$ & \# & $\overrightarrow{\bar{n}}$ & $\mathrm{H}$ & \\
\hline \multirow{8}{*}{ 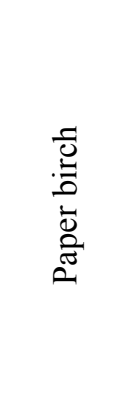 } & \multirow{8}{*}{$\begin{array}{c}0 \\
0 \\
0 \\
0 \\
0 \\
0 \\
0 \\
0 \\
0 \\
0 \\
0 \\
0 \\
0 \\
0\end{array}$} & \multirow[t]{8}{*}{3} & \multirow[t]{8}{*}{$<5$} & 1.5 & \multirow[t]{8}{*}{21} & 10 & 12 & \multirow[t]{8}{*}{36} & 9 & 9 & \multirow[t]{8}{*}{17} & 5 & 4 & \multirow[t]{8}{*}{770} \\
\hline & & & & 1 & & 8 & 6 & & $<5$ & 3 & & 5 & 6 & \\
\hline & & & & 1 & & 10 & 15 & & 11 & 14 & & $<5$ & 3 & \\
\hline & & & & & & 12 & 14 & & 34 & 17 & & & 3 & \\
\hline & & & & & & 10 & 9 & & 10 & 9 & & & 2 & \\
\hline & & & & & & 10 & 12 & & 7 & 8 & & & & \\
\hline & & & & & & $<5$ & 5 & & 8 & 9 & & & & \\
\hline & & & & & & 6 & 6 & & $<5$ & 3 & & & & \\
\hline \multirow{6}{*}{ 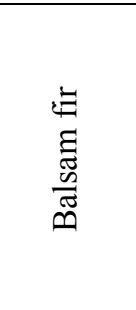 } & \multirow{6}{*}{ 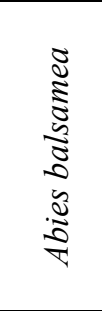 } & \multirow[t]{6}{*}{15} & 5 & 2 & \multirow[t]{6}{*}{94} & 18 & 12 & \multirow[t]{6}{*}{56} & 19 & 17 & \multirow[t]{6}{*}{15} & 5 & 3 & \multirow[t]{6}{*}{1800} \\
\hline & & & $<5$ & 1.5 & & $<5$ & 6 & & 7 & 5 & & $<5$ & 2 & \\
\hline & & & $<5$ & 1.3 & & $<5$ & 4 & & 5 & 5 & & 5 & 2.5 & \\
\hline & & & $<5$ & 1 & & 7 & 5 & & $<5$ & 3 & & 5 & 5 & \\
\hline & & & & & & $<5$ & 2 & & 12 & 11 & & 6 & 5 & \\
\hline & & & & & & & 2 & & $<5$ & 2 & & & & \\
\hline \multirow{3}{*}{ 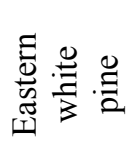 } & \multirow{3}{*}{ 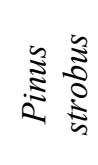 } & \multirow[t]{3}{*}{5} & $<5$ & 1 & & & & \multirow[t]{3}{*}{1} & 35 & 17 & 3 & 11 & 6 & 90 \\
\hline & & & & 1 & & & & & & & & $<5$ & 3 & \\
\hline & & & & 1 & & & & & & & & 5 & 7 & \\
\hline & $\cong$ & 15 & $<5$ & 1 & 13 & 9 & 9 & 9 & 18 & 15 & 25 & $<5$ & 2 & 620 \\
\hline$\stackrel{0}{E}$ & $\stackrel{\Xi}{\Xi}$ & & 6 & 1.5 & & 6 & 5 & & 15 & 16 & & 7 & 4 & \\
\hline $\begin{array}{l}2 \\
y \\
y\end{array}$ & 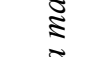 & & 9 & 6 & & 12 & 16 & & 10 & 9 & & 12 & 9 & \\
\hline$\frac{\pi}{\infty}$ & . & & $<5$ & 2 & & & & & 14 & 13 & & 5 & 3 & \\
\hline & 2 & & 11 & 8 & & & & & & & & 5 & 4 & \\
\hline & & 5 & 11 & 8 & 12 & 27 & 13 & 18 & 24 & 14 & 18 & $<5$ & 2 & 530 \\
\hline$\frac{\vec{B}}{3}=$ & 0. & & $<5$ & 2 & & 24 & 14 & & 14 & 13 & & & 2 & \\
\hline$\overline{0} \frac{\pi}{8}$ & $\Xi \Xi$ & & $<5$ & 2 & & 14 & 7 & & 16 & 8 & & 13 & 8 & \\
\hline $\bar{E}^{\circ}$ & $\tilde{y}$ & & $<5$ & 2 & & 23 & 14 & & 5 & 5 & & 24 & 17 & \\
\hline & & & $<5$ & 2 & & 34 & 15 & & 29 & 16 & & $<5$ & 2 & \\
\hline & & 5 & & 5 & & & & & & & 3 & 9 & 10 & 80 \\
\hline$\frac{y}{\tilde{c}}$ & ב & & 6 & 4 & & & & & & & & 7 & 6 & \\
\hline छี & $\frac{5}{5}$ & & 10 & 6 & & & & & & & & & 4 & \\
\hline$\stackrel{\sigma}{\oplus}$ & 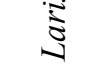 & & & 2 & & & & & & & & & & \\
\hline & & & & 3.5 & & & & & & & & & & \\
\hline
\end{tabular}


Table 27.

Vegetation survey Bete Grise swale

\begin{tabular}{|l|l|c|c|c|c|}
\hline \multicolumn{2}{|c|}{ Bete Grise dune and swale BG6 1x1 m } & \multicolumn{5}{c|}{ Cover class } \\
\hline \multicolumn{2}{|c|}{ Species name } & NE & SE & SW & NW \\
\hline Threeseeded sedge & Carex trisperma & 50 & & & \\
\hline Rattlesnake-mannagrass & Glyceria canadensis & 1 & & & \\
\hline Labrador tea & Ledum groenlandicum & 45 & 5 & 75 & 15 \\
\hline Clubmoss & Lycopodium spp & 5 & & & \\
\hline Creeping snowberry & Gaultheria hispidula & 5 & & & \\
\hline \multicolumn{2}{|c|}{ Bryophytes } & 85 & 80 & 95 & 95 \\
\hline Velvet leaved bilberry & Vaccinium myrtillus & 5 & 5 & 3 & \\
\hline Balsam fir & Abies balsamea & 7 & & & \\
\hline Bluejoint & Calamagrostis canadensis & 3 & & 1 & 2 \\
\hline Northern Blue Flag & Iris versacolor & & 35 & & \\
\hline Three-leaf Solomon's-seal & Maianthemum trifolium & & 1 & & \\
\hline Bracken fern & Pteridium aquilinum & & & 50 & \\
\hline Mountain ash & Sorbus americana & & & 1 & \\
\hline Bunchberry dogwood & Cornus canadensis & & & 7 & \\
\hline Softleaf sedge & Carex disperma & & & 5 & \\
\hline Serviceberry & Amelanchier ssp & & & 1 & \\
\hline Cinnamon fern & Osmunda cinnamomea & 15 & & & 20 \\
\hline Starflower & Trientalis borealis & & & & 5 \\
\hline Three-leaf goldthread & Coptis trifolia & & & & 7 \\
\hline Hairy sedge & Carex lacustris & 3 & & & \\
\hline Dwarf birch & Betula nana & & & & 1 \\
\hline Labrador tea & Ledum groenlandicum & 25 & 10 & 15 & 50 \\
\hline Black spruce & Picea mariana & 25 & & 3 & \\
\hline Tag alder & Alnus incana & 10 & 25 & 7 & 50 \\
\hline Mountain Holly & Nemopanthus mucronata & & 7 & 10 & \\
\hline Paper birch & Betula papyrifera & & 2 & 7 & \\
\hline Velvet leaved bilberry & Vaccinium myrtillus & & & 5 & 15 \\
\hline Tamarack & Larix laricina & $<1$ & & & \\
\hline
\end{tabular}


Table 28.

Vegetation survey Bete Grise swale tree data

\begin{tabular}{|c|c|c|c|c|c|c|c|c|c|c|c|c|c|}
\hline \multicolumn{2}{|c|}{$\begin{array}{c}\text { Trees BG6 } \\
\text { dune \& swale }\end{array}$} & \multicolumn{3}{|c|}{$\mathrm{NE}$} & \multicolumn{3}{|c|}{ SE } & \multicolumn{3}{|c|}{ SW } & \multicolumn{3}{|c|}{ NW } \\
\hline $\begin{array}{l}\text { Common } \\
\text { name }\end{array}$ & $\begin{array}{l}\text { Latin } \\
\text { name }\end{array}$ & \# & $\overrightarrow{\underline{m}}$ & $\mathrm{H}$ & \# & $\stackrel{\square}{\square}$ & $\mathrm{H}$ & \# & 商 & $\mathrm{H}$ & \# & $\overrightarrow{\widetilde{a}}$ & $\mathrm{H}$ \\
\hline 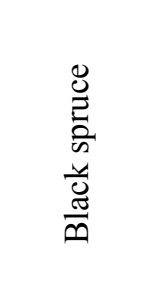 & 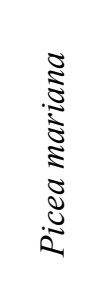 & 3 & $\begin{array}{c}7 \\
15 \\
20\end{array}$ & $\begin{array}{c}5 \\
9 \\
18\end{array}$ & 5 & $\begin{array}{l}5 \\
6 \\
6\end{array}$ & $\begin{array}{l}4 \\
4 \\
5\end{array}$ & 42 & $\begin{array}{c}14 \\
9 \\
16 \\
11 \\
6\end{array}$ & $\begin{array}{c}16 \\
6 \\
16 \\
9 \\
7\end{array}$ & 10 & $\begin{array}{c}14 \\
8\end{array}$ & $\begin{array}{c}11 \\
7\end{array}$ \\
\hline 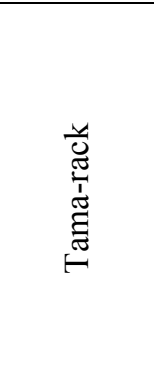 & 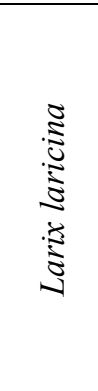 & 3 & $\begin{array}{l}21 \\
15 \\
18\end{array}$ & $\begin{array}{l}16 \\
14 \\
15\end{array}$ & 14 & $\begin{array}{l}7 \\
5 \\
9 \\
8 \\
5\end{array}$ & $\begin{array}{l}5 \\
3 \\
8 \\
7 \\
5\end{array}$ & 30 & $\begin{array}{c}< \\
5 \\
8 \\
< \\
5 \\
10 \\
7 \\
5\end{array}$ & $\begin{array}{l}3 \\
7 \\
2 \\
9 \\
8 \\
5\end{array}$ & 6 & $\begin{array}{l}11 \\
16 \\
14 \\
16 \\
17\end{array}$ & $\begin{array}{c}9 \\
14 \\
8 \\
11 \\
13\end{array}$ \\
\hline 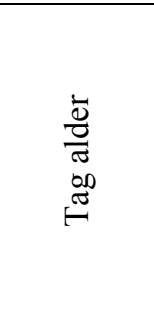 & 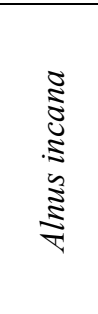 & 72 & $<5$ & $\begin{array}{l}2 \\
3 \\
2 \\
4 \\
2\end{array}$ & 87 & $\begin{array}{l}< \\
5\end{array}$ & $\begin{array}{l}2 \\
2 \\
1 . \\
5 \\
2 \\
2 .\end{array}$ & 27 & $\begin{array}{l}< \\
< \\
\end{array}$ & $\begin{array}{l}2 \\
2 \\
3 \\
2 \\
2\end{array}$ & 42 & $<5$ & $\begin{array}{l}3 \\
2 \\
2 \\
2 \\
3\end{array}$ \\
\hline 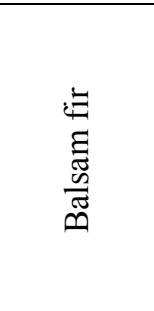 & 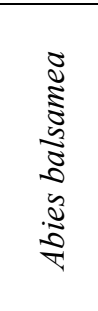 & 11 & $\begin{array}{c}5 \\
<5 \\
12 \\
7\end{array}$ & $\begin{array}{l}2 \\
2 \\
6 \\
5\end{array}$ & 6 & $\begin{array}{l}< \\
5 \\
\\
6\end{array}$ & $\begin{array}{c}1 . \\
5 \\
1 . \\
5 \\
3 \\
1 . \\
5 \\
4\end{array}$ & 9 & $\begin{array}{l}< \\
<\end{array}$ & $\begin{array}{l}2 \\
2 \\
2 \\
3 \\
4\end{array}$ & 11 & $<5$ & $\begin{array}{l}2 \\
2 \\
3 \\
2 \\
3\end{array}$ \\
\hline $\begin{array}{l}\overline{0} \\
\dot{0} \\
\overline{0} \\
\overline{0} \\
\text { है }\end{array}$ & 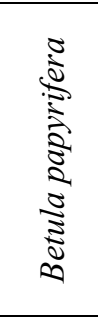 & 9 & $<5$ & $\begin{array}{l}3 \\
2 \\
3 \\
3 \\
4 \\
\end{array}$ & 10 & $<5$ & $\begin{array}{l}2 \\
2 \\
2 \\
3 \\
4\end{array}$ & 9 & $\begin{array}{l}< \\
<\end{array}$ & $\begin{array}{l}2 \\
2 \\
2 \\
4 \\
3 \\
\end{array}$ & 11 & $<5$ & $\begin{array}{l}2 \\
2 \\
3 \\
2 \\
3\end{array}$ \\
\hline
\end{tabular}


Table 28 (continued)

\begin{tabular}{|c|c|c|c|c|c|c|c|c|c|c|c|c|c|}
\hline \multicolumn{2}{|c|}{$\begin{array}{c}\text { Trees BG6 } \\
\text { dune \& swale }\end{array}$} & \multicolumn{3}{|c|}{$\mathrm{NE}$} & \multicolumn{3}{|c|}{ SE } & \multicolumn{3}{|c|}{ SW } & \multicolumn{3}{|c|}{ NW } \\
\hline $\begin{array}{l}\text { Common } \\
\text { name }\end{array}$ & $\begin{array}{l}\text { Latin } \\
\text { name }\end{array}$ & \# & 㺃 & $\mathrm{H}$ & \# & $\overrightarrow{0}$ & $\mathrm{H}$ & \# & 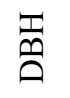 & $\mathrm{H}$ & \# & 容 & $\mathrm{H}$ \\
\hline 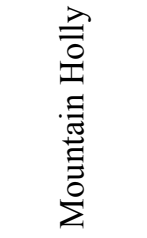 & 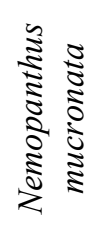 & & & & & & & 6 & $<5$ & 2 & 11 & $<5$ & 2 \\
\hline
\end{tabular}


Table 29.

Vegetation survey Bete Grise dune

\begin{tabular}{|l|l|c|c|c|c|}
\hline \multicolumn{2}{|c|}{ Bete Grise dune and swale well 8 1x1 m } & \multicolumn{5}{c|}{ Cover class } \\
\hline \multicolumn{1}{|c|}{ Species name } & Epigaea repens & NE & SE & SW & NW \\
\hline Mayflower & Vaccinium angustifolium & 25 & & & 25 \\
\hline Lowbush blueberry & Vaccinium myrtillus & 60 & & & 25 \\
\hline Velvet leaved bilberry & Bryophytes & 50 & 50 & 10 & 55 \\
\hline \multicolumn{7}{|c|}{ Ledum groenlandicum } & 35 & & & 35 \\
\hline Labrador tea & Pteridium aquilinium & 25 & & & 40 \\
\hline Bracken fern & Cornus canadensis & & & 1 & 5 \\
\hline Bunchberry dogwood & Salix spp & & & 25 & \\
\hline Willow & Chamaedaphne calyculata & & 25 & 25 & \\
\hline Leatherleaf & Carex oligosperma & & 75 & 60 & \\
\hline Few-seeded sedge & Calamagrostis canadensis & & & 20 & \\
\hline Blue joint & Kalmia polifolia & & 2 & 5 & \\
\hline Bog-laurel & Andromeda polifolia & & 7 & & \\
\hline Bog-rosemary & Vaccinium oxycoccus & & 5 & & \\
\hline Small cranberry & Betula pumila & & $<1$ & & \\
\hline Bog birch & 3X3 m & NE & SE & SW & NW \\
\hline \multicolumn{2}{|c|}{ Ledum groenlandicum } & 25 & & & 30 \\
\hline Labrador tea & Picea mariana & 3 & 1 & 1 & \\
\hline Black spruce & Chamaedaphne calyculata & 4 & 5 & 16 & \\
\hline Leatherleaf & Nemopanthus mucronata & & & & 10 \\
\hline Mountain Holly & Salix spp & & 40 & 20 & \\
\hline Willow & & & \\
\hline
\end{tabular}


Table 30.

Vegetation survey Bete Grise dune tree data

\begin{tabular}{|c|c|c|c|c|c|c|c|c|c|c|c|c|c|c|}
\hline \multicolumn{2}{|c|}{$\begin{array}{c}\text { Trees BG8 } \\
\text { Dune \& swale }\end{array}$} & \multicolumn{3}{|c|}{$\mathrm{NE}$} & \multicolumn{3}{|c|}{ SE } & \multicolumn{3}{|c|}{ SW } & \multicolumn{3}{|c|}{ NW } & t \\
\hline $\begin{array}{l}\text { Common } \\
\text { name }\end{array}$ & Latin name & \# & $\stackrel{T}{\stackrel{T}{0}}$ & $\mathrm{H}$ & \# & $\stackrel{\mathbb{m}}{\tilde{0}}$ & $\mathrm{H}$ & $\#$ & $\stackrel{T}{\stackrel{T}{0}}$ & $\mathrm{H}$ & \# & $\stackrel{\vec{m}}{\underline{0}}$ & $\mathrm{H}$ & ha \\
\hline 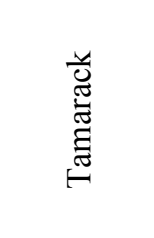 & 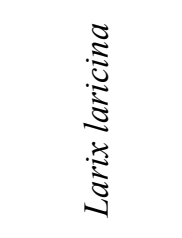 & 2 & $<5$ & $\begin{array}{c}1.5 \\
2\end{array}$ & 6 & $\begin{array}{c}<5 \\
6 \\
<5\end{array}$ & $\begin{array}{l}2 \\
9 \\
3\end{array}$ & 15 & $\begin{array}{c}6 \\
5 \\
11 \\
8\end{array}$ & $\begin{array}{c}5 \\
6 \\
10 \\
8\end{array}$ & 1 & 7 & 4 & 240 \\
\hline 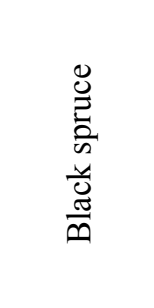 & 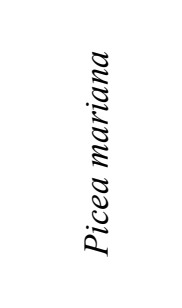 & 18 & $\begin{array}{l}<5 \\
13 \\
10 \\
13 \\
12\end{array}$ & $\begin{array}{c}1.5 \\
8 \\
6 \\
9 \\
10\end{array}$ & 20 & $\begin{array}{c}<5 \\
12 \\
7 \\
14 \\
<5\end{array}$ & $\begin{array}{c}3 \\
11 \\
13 \\
10 \\
15\end{array}$ & 7 & $\begin{array}{c}7 \\
9 \\
<5\end{array}$ & $\begin{array}{l}5 \\
9 \\
3\end{array}$ & 10 & $\begin{array}{c}12 \\
9\end{array}$ & $\begin{array}{c}10 \\
7\end{array}$ & 550 \\
\hline$\stackrel{\frac{3}{0}}{\frac{1}{3}}$ & हूँ & 2 & $<5$ & 5 & & & & 1 & $<5$ & 2 & & & & 30 \\
\hline 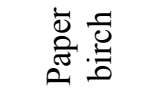 & 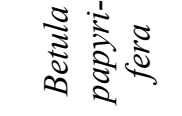 & 1 & 10 & 9 & 1 & $<5$ & 6 & 1 & 9 & 9 & 1 & $\begin{array}{l}< \\
5\end{array}$ & 3 & 40 \\
\hline 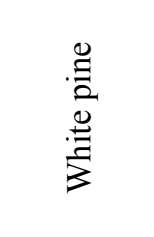 & 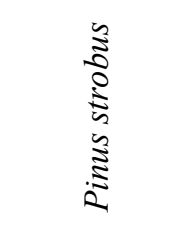 & 1 & 28 & 16 & 6 & $\begin{array}{l}<5 \\
6 \\
<5 \\
<5\end{array}$ & $\begin{array}{c}1.5 \\
2 \\
4 \\
1.5\end{array}$ & 1 & 6 & 4 & 3 & $\begin{array}{l}29 \\
22 \\
30\end{array}$ & $\begin{array}{l}12 \\
10 \\
11\end{array}$ & 110 \\
\hline 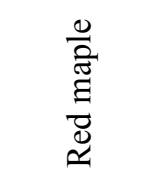 & 离 & 2 & $\begin{array}{l}<5 \\
<5\end{array}$ & $\begin{array}{l}3 \\
2\end{array}$ & & & & & & & & & & 20 \\
\hline 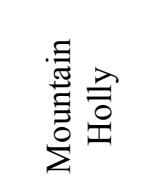 & 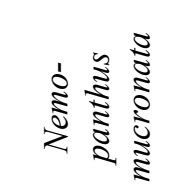 & 8 & $<5$ & $\begin{array}{c}2 \\
2 \\
1.5\end{array}$ & 3 & $<5$ & $\begin{array}{c}2 \\
1.5\end{array}$ & 9 & $<5$ & 2 & & & & 110 \\
\hline
\end{tabular}


Table 30 (continued)

\begin{tabular}{|c|c|c|c|c|c|c|c|c|c|c|c|c|c|}
\hline \multicolumn{2}{|c|}{$\begin{array}{c}\text { Trees BG8 } \\
\text { Dune \& swale }\end{array}$} & \multicolumn{3}{|c|}{ NE } & \multicolumn{3}{|c|}{ SE } & \multicolumn{3}{|c|}{ SW } & \multicolumn{3}{|c|}{ NW } \\
\hline $\begin{array}{c}\text { Common } \\
\text { name }\end{array}$ & Latin name & \# & $\stackrel{\square}{0}$ & $\mathrm{H}$ & $\#$ & $\stackrel{\mathbb{m}}{\vec{a}}$ & $\mathrm{H}$ & \# & $\stackrel{\mathbb{m}}{\vec{n}}$ & $\mathrm{H}$ & \# & 氶 & $\mathrm{H}$ \\
\hline 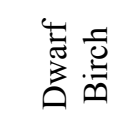 & 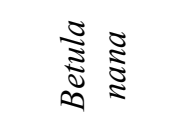 & & & & 3 & $<5$ & 3 & & & & & & \\
\hline 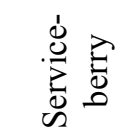 & 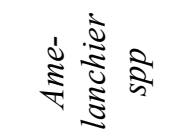 & & & & 1 & $<5$ & 2 & 1 & $<5$ & 2 & & & \\
\hline
\end{tabular}


Table 31.

Vegetation survey Pequaming open fen

\begin{tabular}{|c|c|c|c|c|c|}
\hline \multicolumn{2}{|c|}{ Pequaming PQ2 open fen 1x1 m } & \multicolumn{4}{|c|}{ Cover class } \\
\hline Common name & Latin name & NE & SE & SW & NW \\
\hline \multicolumn{2}{|c|}{ Surface water } & 25 & 30 & $1-5$ & 20 \\
\hline \multicolumn{2}{|c|}{ Bryophytes } & 60 & 60 & 65 & \\
\hline Bog-rosemary & Andromeda polifolia & 25 & $5-10$ & $10-15$ & $10-15$ \\
\hline Leatherleaf & Chamaedaphne calyculata & $5-10$ & $1-5$ & $5-10$ & \\
\hline Cranberry & Vaccinium oxycoccus & $1-5$ & $1-5$ & $1-5$ & \\
\hline Bog Golden rod & Solidago uliginosa & $5-10$ & $1-5$ & $10-15$ & $1-5$ \\
\hline Pitcher plant & Sarracenia purpurea & $1-5$ & $1-5$ & $15-20$ & \\
\hline Violet & Viola spp. & $10-15$ & & & \\
\hline Willow herb & Epilobium palustre & $<1$ & & & \\
\hline Marsh timothy & Muhlenbergia glomerata & $<1$ & & & \\
\hline Horsetail & Equisetum spp & $<1$ & & $1-5$ & 30 \\
\hline Wiresedge & Carex lasiocarpa & 75 & 40 & 65 & 60 \\
\hline Spikerush & Eleocharis spp & $1-5$ & & & \\
\hline Bulrush & Scripus spp & $1-5$ & $1-5$ & $1-5$ & \\
\hline Royal fern & Osmunda regalis & & $10-15$ & $10-15$ & \\
\hline Tamarack & Larix laricina & & 15 & & \\
\hline Red maple & Acer rubrum & & & $<1$ & \\
\hline Chokeberry & Aronia melanocarpa & & & $1-5$ & \\
\hline Northern white cedar & Thuja occidentalis & & & 40 & \\
\hline Mountain Holly & Nemopanthis mucronata & & & & 15 \\
\hline Bog bean & Menyanthes trifoliata & & & & $<1$ \\
\hline Bog birch & Betula pumila & & & & $<1$ \\
\hline \multicolumn{2}{|c|}{$3 \times 3 \mathrm{~m}$} & $\mathrm{NE}$ & SE & SW & NW \\
\hline Tamarack & Larix laricina & $1-5$ & $1-5$ & $<1$ & $1-5$ \\
\hline Northern white cedar & Thuja occidentalis & $10-15$ & $5-10$ & $1-5$ & $5-10$ \\
\hline Sweetgale & Myrica gale & 25 & & $10-15$ & \\
\hline Black spruce & Picea mariana & $1-5$ & & & \\
\hline Black Chokeberry & Aronia melanocarpa & & & & $<1$ \\
\hline Willow & Salix spp & & & & $<1$ \\
\hline
\end{tabular}


Table 32.

Vegetation survey Pequaming open fen tree data

\begin{tabular}{|c|c|c|c|c|c|c|c|c|c|c|c|c|c|}
\hline \multicolumn{2}{|c|}{$\begin{array}{c}\text { Trees PQ2 } \\
\text { Open fen }\end{array}$} & \multicolumn{3}{|c|}{$\mathrm{NE}$} & \multicolumn{3}{|c|}{$\mathrm{SE}$} & \multicolumn{3}{|c|}{ SW } & \multicolumn{3}{|c|}{ NW } \\
\hline $\begin{array}{l}\text { Common } \\
\text { name }\end{array}$ & Latin name & $\#$ & $\frac{m}{0}$ & $\mathrm{H}$ & $\#$ & $\frac{\mathbb{m}}{0}$ & $\mathrm{H}$ & $\#$ & $\frac{\mathbb{m}}{0}$ & $\mathrm{H}$ & \# & $\stackrel{\frac{m}{0}}{a}$ & $\mathrm{H}$ \\
\hline $\begin{array}{l}\text { Northern } \\
\text { white cedar }\end{array}$ & $\begin{array}{l}\text { Thuja } \\
\text { occidentalis }\end{array}$ & 1 & $<5$ & 1.5 & 1 & $<5$ & 2 & 1 & $<5$ & 1.5 & 1 & $<5$ & 1.5 \\
\hline Tamarack & $\begin{array}{l}\text { Larix } \\
\text { laricina }\end{array}$ & 1 & $<5$ & 1.5 & 2 & $<5$ & $\begin{array}{c}1.5 \\
2\end{array}$ & 2 & $<5$ & $\begin{array}{l}1.5 \\
1.5\end{array}$ & 1 & $<5$ & 1.5 \\
\hline Paper birch & $\begin{array}{l}\text { Betula } \\
\text { papyrifera }\end{array}$ & 1 & $<5$ & 1.5 & & & & & & & & & \\
\hline
\end{tabular}


Table 33.

Vegetation survey Pequaming transition zone

\begin{tabular}{|c|c|c|c|c|c|}
\hline \multicolumn{2}{|c|}{ Pequaming PQ5 transition $1 \times 1 \mathrm{~m}$} & \multicolumn{4}{|c|}{ Cover class } \\
\hline Common name & Latin name & NE & SE & SW & NW \\
\hline Hairy sedge & Carex lacustris & & & 5 & $1-5$ \\
\hline Bristlystalked sedge & Carex leptalea & & & 20 & $1-5$ \\
\hline Horsetail & Equisetum spp & $5-10$ & 30 & $40-50$ & 40 \\
\hline Labrador tea & Ledum groenlandicum & 10 & $15-20$ & $15-20$ & $1-5$ \\
\hline Three-leaf Solomon's-seal & Maianthemum trifolium & 1 & & & \\
\hline Few seeded sedge & Carex trisperma & $5-10$ & 1 & $1-5$ & \\
\hline \multicolumn{2}{|c|}{ Bryophytes } & 85 & 90 & 100 & 80 \\
\hline Royal fern & Osmunda regalis & $25-30$ & & & 25 \\
\hline Starflower & Trientalis borealis & $<1$ & $1-5$ & $<1$ & \\
\hline Northern white cedar & Thuja occidentalis & 1 & $1-5$ & & $10-15$ \\
\hline White turtlehead & Chleone glabra & $1-5$ & & $<1$ & \\
\hline Small cranberry & Vaccinium oxycoccus & $<1$ & & $5-10$ & $<1$ \\
\hline Michaux's sedge & Carex michaux & $1-5$ & & & \\
\hline Liverleaf wintergreen & Pyrola asarifolia & $<1$ & $10-15$ & & $5-10$ \\
\hline Tag alder & Alnus incana & & 1 & $5-10$ & \\
\hline Bluejoint & Calamagrostis canadensis & & 1 & $1-5$ & 30 \\
\hline Sedge (orange roots) & Carex limosa & & & $1-5$ & \\
\hline Canada mayflower & Maianthemum canadense & & & & $1-5$ \\
\hline \multicolumn{2}{|c|}{$3 \times 3 \mathrm{~m}$} & $\mathrm{NE}$ & SE & SW & NW \\
\hline Tag alder & Alnus incana & $5-15$ & $1-5$ & 15 & $1-5$ \\
\hline Northern white cedar & Thuja occidentalis & $5-10$ & $1-5$ & $25-30$ & $5-10$ \\
\hline Labrador tea & Ledum groenlandicum & $1-5$ & $5-10$ & $1-5$ & $1-5$ \\
\hline Mountain Holly & Ilex mucronata & & $1-5$ & $<1$ & \\
\hline Leatherleaf & Chamaedaphne calyculata & & & $1-5$ & \\
\hline Tamarack & Larix laricina & & & $<1$ & \\
\hline
\end{tabular}


Table 34.

Vegetation survey Pequaming transition zone tree data

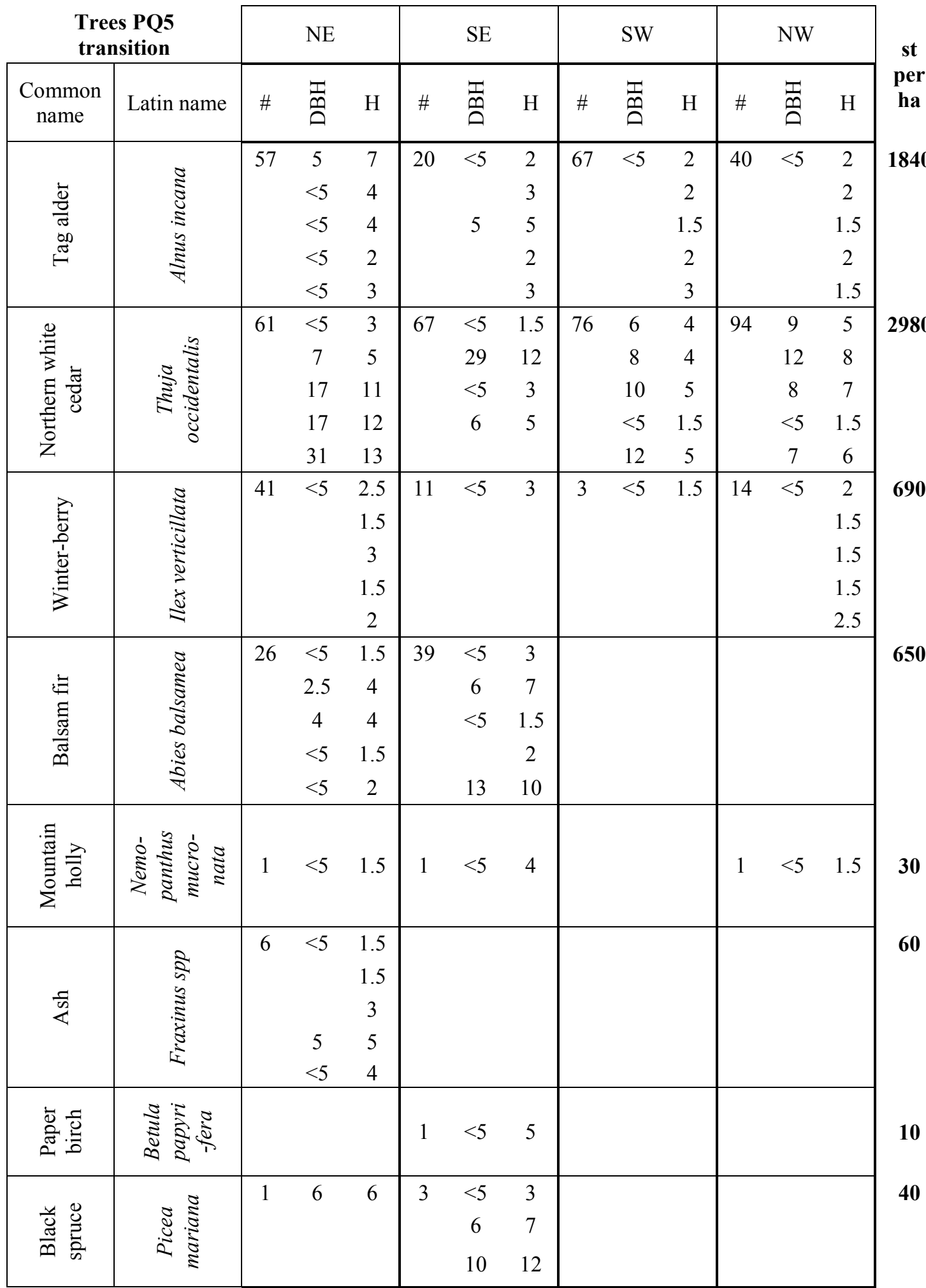


Table 35.

Vegetation survey Pequaming upland

\begin{tabular}{|c|c|c|c|c|c|}
\hline \multicolumn{2}{|c|}{ Pequaming upland 1x1 m } & \multicolumn{4}{|c|}{ Cover class } \\
\hline Common name & Latin name & $\mathrm{NE}$ & SE & SW & NW \\
\hline labrador tea & Ledum groenlandicum & 7 & $1-5$ & & $1-5$ \\
\hline Creeping snowberry & Gaultheria hispidula & 5 & $<1$ & $1-5$ & \\
\hline Cinnamon fern & Osmunda cinnamomea & & & 30 & \\
\hline Lowbush blueberry & Vaccinium angustifolium & & & $1-5$ & \\
\hline Starflower & Trientalis borealis & $1-5$ & $1-5$ & & \\
\hline Mayflower & Epigaea repens & $1-5$ & $5-10$ & & \\
\hline \multicolumn{2}{|c|}{ Bryophytes } & 85 & 25 & $10-15$ & 35 \\
\hline Twinflower & Linnaea borealis & $1-5$ & & & \\
\hline Horsetail & Equisetum ssp & 1 & & & $1-5$ \\
\hline Fowl manna grass & Glyceria striata & $1-5$ & & 25 & $1-5$ \\
\hline Northern white cedar & Thuja occidentalis & 20 & $10-15$ & $1-5$ & 40 \\
\hline Red maple & Acer rubrum & $<1$ & & & \\
\hline Clubmoss & Lycopodium spp & $<1$ & $<1$ & $1-5$ & \\
\hline Three-seeded sedge & Carex trisperma & 30 & $1-5$ & $5-10$ & $5-10$ \\
\hline Balsam fir & Abies balsamea & $5-10$ & $1-5$ & $1-5$ & \\
\hline Marsh marygold & Caltha palustris & & & & $<1$ \\
\hline White turtlehead & Chleone glabra & & & & $<1$ \\
\hline Royal fern & Osmunda regalis & & & & $10-15$ \\
\hline Three-leaf goldthread & Coptis trifolia & & $<1$ & $<1$ & \\
\hline Wintergreen & Gaultheria & & $1-5$ & & \\
\hline Michaux's sedge & Carex michauxiana & & & $5-10$ & \\
\hline \multicolumn{2}{|c|}{$3 \times 3 \mathrm{~m}$} & $\mathrm{NE}$ & SE & SW & NW \\
\hline Mountain Holly & Nemopanthis mucronata & 5 & & & $<1$ \\
\hline Northern white cedar & Thuja occidentalis & $5-25$ & 25 & & 75 \\
\hline Balsam fir & Abies balsamea & 50 & & 50 & $5-10$ \\
\hline Green Ash & Fraxinus Pennsylvanica & $<1$ & & & \\
\hline Tag alder & Alnus incana & $1-5$ & & & $1-5$ \\
\hline Mountain Holly & Ilex mucronata & $5-10$ & & 1 & $<5$ \\
\hline Red maple & Acer rubrum & & & & $<1$ \\
\hline Labrador tea & Ledum groenlandicum & & $1-5$ & 1 & $<1$ \\
\hline
\end{tabular}


Table 36.

Vegetation survey Pequaming upland tree data

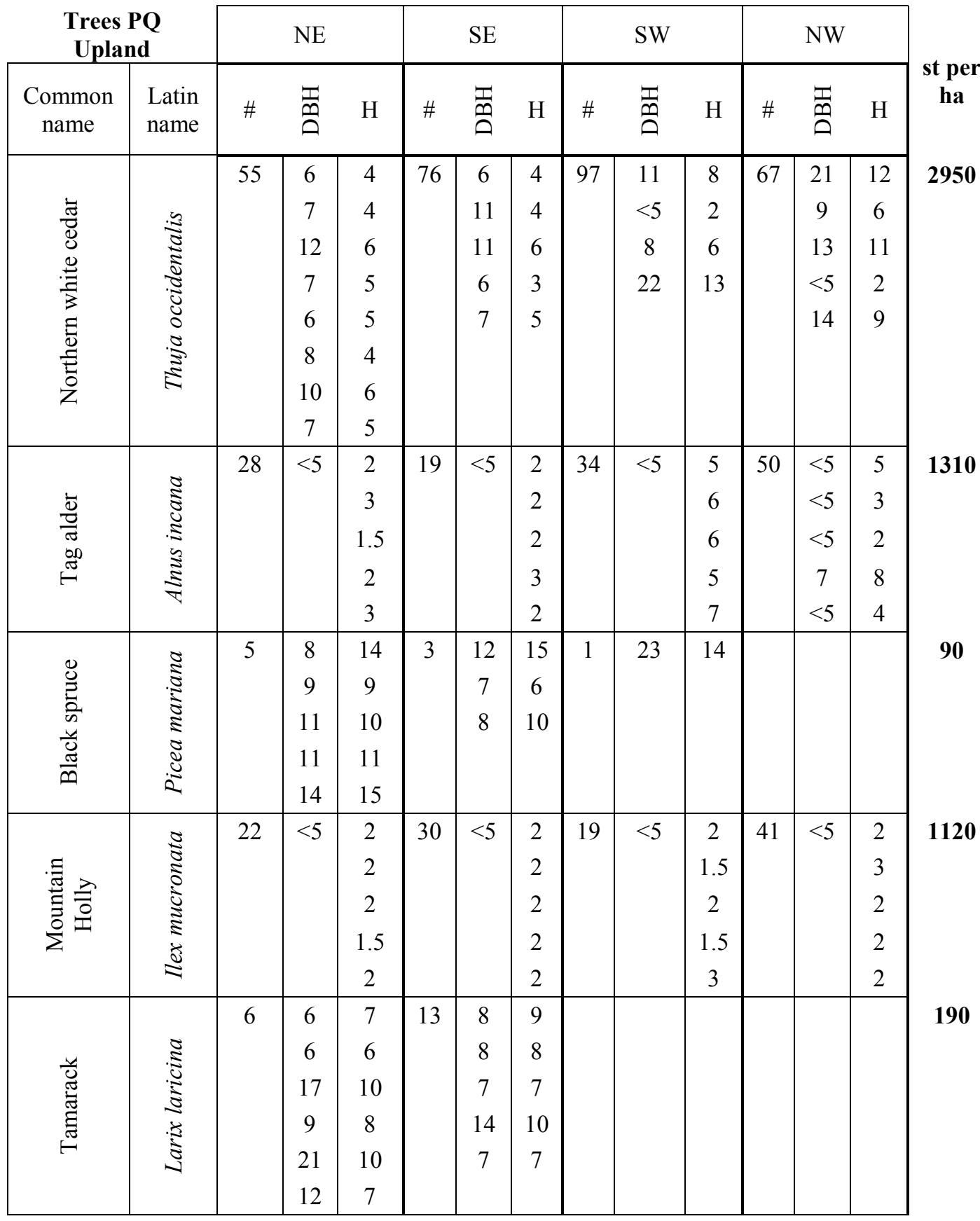


Table 36 (continued)

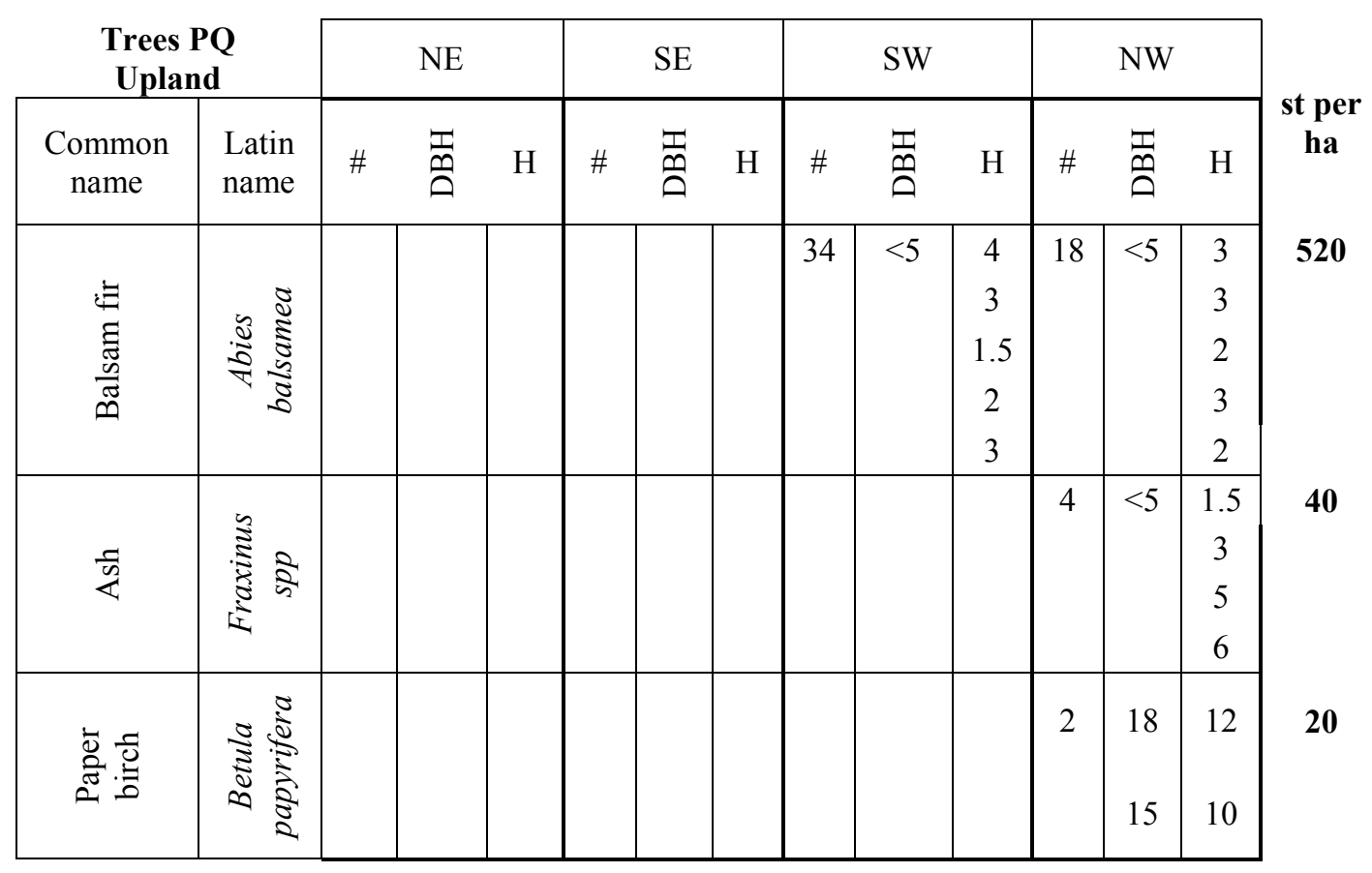


Table 37.

Vegetation survey Lightfoot Bay open fen

\begin{tabular}{|c|c|c|c|c|c|}
\hline \multicolumn{2}{|c|}{ Lightfoot Bay LB2 open fen 1x1 m } & \multicolumn{4}{|c|}{ Cover class } \\
\hline Common name & Latin name & $\mathrm{NE}$ & $\mathrm{SE}$ & SW & NW \\
\hline Bog-rosemary & Andromeda polifolia & 1 & 2 & & 1 \\
\hline Narrow-panicle rush & Juncus brevicaudatus & 60 & 25 & 35 & 40 \\
\hline \multicolumn{2}{|c|}{ Bryophytes } & 35 & 25 & 20 & 45 \\
\hline Violet & Viola spp & 2 & 2 & & \\
\hline Small cranberry & Vaccinium oxycoccus & 2 & 5 & 4 & 1 \\
\hline Horsetail & Equisetum ssp & 1 & 1 & & 3 \\
\hline Spiked muhly & Muhlenbergia glomerata & 5 & 15 & & 4 \\
\hline Sweet Gale & Myrica gale & 15 & 4 & & 6 \\
\hline American Winterberry & Ilex verticillata & 1 & & & \\
\hline Black Chokeberry & Aronia melanocarpa & 1 & & & 5 \\
\hline Bog golden rod & Solidago uliginosa & 1 & 2 & 4 & 5 \\
\hline Pitcher plant & Sarracenia purpurea & 2 & 25 & 10 & 10 \\
\hline Bog bean & Menyanthes trifoliata & & 1 & 3 & \\
\hline Royal fern & Osmunda regalis & & & & \\
\hline Clubmoss & Lycopodium spp & & 1 & & \\
\hline Red maple & Acer rubrum & & 1 & & \\
\hline Ash & Fraxinus ssp & & & 1 & \\
\hline Northern white cedar & Thuja occidentalis & & & & 15 \\
\hline Softleaf sedge & Carex disperma & & & & 3 \\
\hline \multicolumn{2}{|c|}{$3 \times 3 \mathrm{~m}$} & $\mathrm{NE}$ & $\mathrm{SE}$ & SW & $\mathrm{NW}$ \\
\hline $\begin{array}{l}\text { Northern white cedar } \\
\text { saplings }\end{array}$ & $220 /$ ha & & & & \\
\hline
\end{tabular}


Table 38.

Vegetation survey Lightfoot Bay transition zone

\begin{tabular}{|c|c|c|c|c|c|}
\hline \multicolumn{2}{|c|}{ Lightfoot Bay LB5 transition 1x1m } & \multicolumn{4}{|c|}{ Cover class } \\
\hline Common name & Latin name & $\mathrm{NE}$ & $\mathrm{SE}$ & SW & NW \\
\hline Sweet Gale & Myrica gale & 15 & 3 & 10 & 5 \\
\hline Tag alder & Alnus incana & 7 & & & \\
\hline Leatherleaf & Chamaedaphne calyculata & 15 & 10 & 25 & \\
\hline Bog-rosemary & Andromeda polifolia & 7 & 3 & 25 & \\
\hline \multicolumn{2}{|c|}{ Bryophytes } & 100 & 5 & 50 & \\
\hline Starflower & Trientalis borealis & 3 & & & 2 \\
\hline Dwarf raspberry & Rubus pubescens & 15 & 5 & 2 & 10 \\
\hline Swamp rose & Rosa palustris & 7 & & 25 & \\
\hline Bog bean & Menyanthes trifoliata & 10 & & 1 & \\
\hline Pitcher plant & Sarracenia purpurea & 5 & & & \\
\hline Slender sedge & Carex lasiocarpa & 15 & 5 & 40 & 15 \\
\hline Horsetail & Equisetum ssp & 10 & $<1$ & 2 & 5 \\
\hline Spikerush & Eleocharis ssp & 5 & & & \\
\hline Small cranberry & Vaccinium oxycoccus & 3 & 4 & 15 & 10 \\
\hline Black chokeberry & Aronia melanocarpa & 1 & & & 1 \\
\hline Bluejoint & Calamagrostis canadensis & 3 & & & \\
\hline Willow & Salix spp & 1 & $<1$ & & \\
\hline Royal fern & Osmunda regalis & 10 & 75 & & 40 \\
\hline Labrador tea & Ledum groenlandicum & & 2 & & 7 \\
\hline Sedge & Carex ssp & & 15 & & \\
\hline Northern bugleweed & Lycopus uniflorus & & & 8 & \\
\hline Red maple & Acer rubrum & & & 1 & 4 \\
\hline Bog-laurel & Kalmia polifolia & & & & 1 \\
\hline \multicolumn{2}{|c|}{$3 \times 3 \mathrm{~m}$} & $\mathrm{NE}$ & $\mathrm{SE}$ & SW & NW \\
\hline Sweet Gale & Myrica gale & 90 & 80 & 95 & 30 \\
\hline Tag alder & Alnus incana & 10 & 2 & 5 & 7 \\
\hline American Winterberry & Ilex verticillata & 50 & 15 & & 30 \\
\hline Mountain Holly & Nemopanthus mucronata & 10 & 15 & 15 & \\
\hline Black Chokeberry & Aronia melanocarpa & 1 & $<5$ & 5 & \\
\hline Leatherleaf & Chamaedaphne calyculata & & $5-10$ & 20 & 25 \\
\hline Bog-rosemary & Andromeda polifolia & & 1 & & 5 \\
\hline Red maple & Acer rubrum & & & 1 & \\
\hline Labrador tea & Ledum groenlandicum & & & 1 & $<5$ \\
\hline Willow & Salix spp & & & 1 & \\
\hline Serviceberry & Amelanchier $s p$ & & & & $<1$ \\
\hline
\end{tabular}


Table 39.

Vegetation survey Lightfoot Bay transition zone tree data

\begin{tabular}{|c|c|c|c|c|c|c|c|c|c|c|c|c|c|c|}
\hline \multicolumn{2}{|c|}{$\begin{array}{l}\text { Trees LB5 } \\
\text { transition }\end{array}$} & \multicolumn{3}{|c|}{$\mathrm{NE}$} & \multicolumn{3}{|c|}{ SE } & \multicolumn{3}{|c|}{ SW } & \multicolumn{3}{|c|}{ NW } & \\
\hline $\begin{array}{l}\text { Common } \\
\text { name }\end{array}$ & $\begin{array}{l}\text { Latin } \\
\text { name }\end{array}$ & \# & 嵒 & $\mathrm{H}$ & \# & $\stackrel{\square}{\bar{n}}$ & $\mathrm{H}$ & $\#$ & 丞 & $\mathrm{H}$ & \# & $\stackrel{\mathbb{M}}{\underline{0}}$ & $\mathrm{H}$ & ha \\
\hline \multirow{5}{*}{ 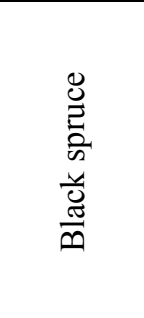 } & \multirow{5}{*}{ 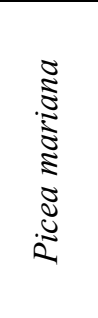 } & \multirow[t]{5}{*}{4} & 5 & 3 & \multirow[t]{5}{*}{3} & 7 & 4.5 & \multirow[t]{5}{*}{1} & \multirow[t]{5}{*}{$<5$} & \multirow[t]{5}{*}{2} & \multirow[t]{5}{*}{7} & $<5$ & 2 & 150 \\
\hline & & & 5 & 2 & & $<5$ & 1.5 & & & & & & 1.5 & \\
\hline & & & $<5$ & $\frac{1 .}{5}$ & & & & & & & & & 3 & \\
\hline & & & & $\begin{array}{l}1 . \\
5\end{array}$ & & & & & & & & & 2 & \\
\hline & & & & & & & & & & & & 5 & 4 & \\
\hline \multirow{5}{*}{ 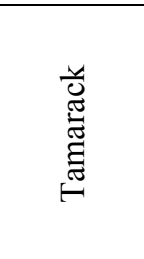 } & \multirow{5}{*}{ 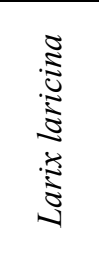 } & \multirow[t]{5}{*}{28} & 6 & 4 & \multirow[t]{5}{*}{30} & $<5$ & 2 & \multirow[t]{5}{*}{24} & $<5$ & 2.5 & \multirow[t]{5}{*}{29} & 7 & 4 & 1110 \\
\hline & & & 4 & 4 & & $<5$ & 2 & & 6 & 3.5 & & $<5$ & 2.5 & \\
\hline & & & 7 & 4 & & 6 & 2.5 & & 5.5 & 3 & & 6 & 4 & \\
\hline & & & 6 & 4 & & 7 & 5 & & $<5$ & 2 & & 6 & 3 & \\
\hline & & & $<5$ & 2 & & $<5$ & 3 & & 5 & 3 & & 7 & 5 & \\
\hline \multirow{5}{*}{ 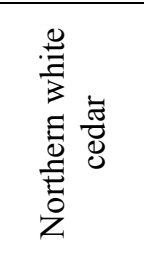 } & \multirow{5}{*}{ 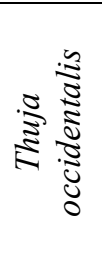 } & \multirow[t]{5}{*}{17} & 15 & 5 & \multirow[t]{5}{*}{9} & 6 & 3 & \multirow[t]{5}{*}{4} & 6 & 3 & \multirow[t]{5}{*}{18} & 7 & 4 & \multirow[t]{5}{*}{480} \\
\hline & & & 8 & 4 & & 11 & 6 & & 6 & 4 & & $<5$ & 3 & \\
\hline & & & 11 & 5 & & 11 & 5 & & 10 & 5 & & 7 & 4 & \\
\hline & & & 8 & 4 & & 7 & 5 & & 9 & 5 & & 6 & 3 & \\
\hline & & & & & & 8 & 4 & & & & & & & \\
\hline$\stackrel{\infty}{\oplus} \frac{\bar{\theta}}{\sigma}$ & 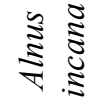 & 5 & $<5$ & 2 & & & & & & & 1 & $<5$ & 2 & 60 \\
\hline \multirow{5}{*}{$\begin{array}{l}\frac{0}{0} \\
\stackrel{\Xi}{\Xi} \\
\overrightarrow{0} \\
\simeq\end{array}$} & \multirow{5}{*}{ 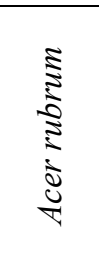 } & \multirow[t]{5}{*}{3} & $<5$ & 4 & 4 & $<5$ & 2 & 1 & $<5$ & 4 & 7 & $<5$ & 2 & 150 \\
\hline & & & & 2 & & & 3 & & & & & & 1.5 & \\
\hline & & & & 2 & & & 2 & & & & & & 5.5 & \\
\hline & & & & & & 5 & 5 & & & & & & 2 & \\
\hline & & & & & & $<5$ & 2 & & & & & & & \\
\hline 尝站 & 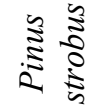 & 1 & $<5$ & 2 & 1 & 8.5 & 6 & 1 & 11 & 6.5 & & & & 30 \\
\hline 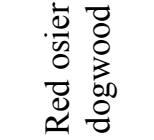 & 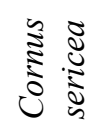 & 3 & $<5$ & 2 & & & & & & & 2 & $<5$ & 2 & 50 \\
\hline
\end{tabular}


Table 39 (continued)

\begin{tabular}{|c|c|c|c|c|c|c|c|c|c|c|c|c|c|}
\hline \multicolumn{2}{|c|}{$\begin{array}{l}\text { Trees LB5 } \\
\text { transition }\end{array}$} & \multicolumn{3}{|c|}{$\mathrm{NE}$} & \multicolumn{3}{|c|}{ SE } & \multicolumn{3}{|c|}{ SW } & \multicolumn{3}{|c|}{ NW } \\
\hline $\begin{array}{c}\text { Common } \\
\text { name }\end{array}$ & $\begin{array}{l}\text { Latin } \\
\text { name }\end{array}$ & \# & $\overrightarrow{\mathscr{n}}$ & $\mathrm{H}$ & $\#$ & 票 & $\mathrm{H}$ & $\#$ & 商 & $\mathrm{H}$ & \# & $\overrightarrow{\widetilde{n}}$ & $\mathrm{H}$ \\
\hline 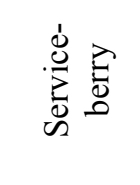 & 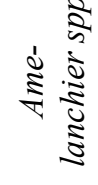 & 1 & $<5$ & $\begin{array}{l}1 . \\
5\end{array}$ & & & & & & & & & \\
\hline $\begin{array}{l}\frac{d}{y} \\
\frac{y}{0} \\
\frac{d}{0} \\
\frac{y}{0} \\
\frac{\vec{d}}{m}\end{array}$ & 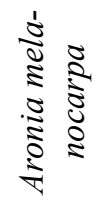 & & & & & & & & & & 1 & $<5$ & 1.5 \\
\hline 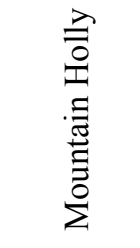 & 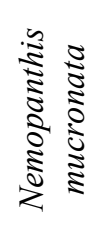 & & & & & & & & & & 1 & $<5$ & 1.5 \\
\hline 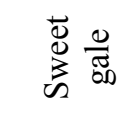 & 芯 & & & & & & & & & & 1 & $<5$ & 1.5 \\
\hline 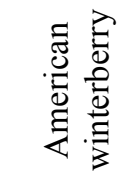 & 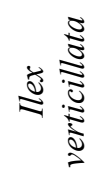 & & & & & & & & & & 2 & $<5$ & 2 \\
\hline
\end{tabular}


Table 40.

Vegetation survey Lightfoot Bay upland

\begin{tabular}{|c|c|c|c|c|c|}
\hline \multicolumn{2}{|c|}{ LB upland 1x1m } & \multicolumn{4}{|c|}{ Cover class } \\
\hline Common name & Latin name & $\mathrm{NE}$ & SE & SW & NW \\
\hline \multicolumn{2}{|c|}{ Bryophytes } & 100 & 25 & 20 & 60 \\
\hline Royal fern & Osmunda regalis & 25 & & & 30 \\
\hline Black spruce & Picea mariana & $5-10$ & & & \\
\hline Red maple & Acer rubrum & 5 & 30 & 10 & 2 \\
\hline Brownish sedge & Carex brunnescens & 15 & & & 15 \\
\hline Starflower & Trientalis borealis & 5 & & & 5 \\
\hline Three-leaf goldthread & Coptis trifolia & 2 & 6 & & \\
\hline Bunchberry dogwood & Cornus canadensis & 7 & 10 & & \\
\hline Yellow birch & Betula alleghaniensis & 7 & 2 & 5 & \\
\hline Blue bead lily & Clintonia borealis & 1 & 2 & 5 & \\
\hline Trailing arbutus & Epigaea repens & & 1 & & \\
\hline Wood sorrel & Oxalis spp & & $<1$ & & \\
\hline Creeping snowberry & Gaultheria hispidula & & $<1$ & & \\
\hline Eastern Hemlock & Tsuga canadensis & 1 & $<1$ & 3 & \\
\hline Clubmoss & Lycopodium spp & & & 3 & \\
\hline American Winterberry & Ilex verticillata & & 4 & 5 & 5 \\
\hline Canada Mayflower & Maianthemum canadense & & 4 & 5 & \\
\hline \multicolumn{2}{|c|}{$3 \times 3 \mathrm{~m}$} & $\mathrm{NE}$ & SE & SW & NW \\
\hline Black spruce & Picea mariana & 7 & & & 5 \\
\hline Yellow birch & Betula alleghaniensis & 10 & 5 & 5 & 5 \\
\hline American Winterberry & Ilex verticillata & 3 & & & 30 \\
\hline Common bilberry & Vaccinium myrtillus & & & 5 & \\
\hline Eastern Hemlock & Tsuga canadensis & 15 & & & \\
\hline
\end{tabular}


Table 41.

Vegetation survey Lightfoot Bay upland tree data

\begin{tabular}{|c|c|c|c|c|c|c|c|c|c|c|c|c|c|}
\hline \multicolumn{2}{|c|}{$\begin{array}{c}\text { Trees LB } \\
\text { upland }\end{array}$} & \multicolumn{3}{|c|}{$\mathrm{NE}$} & \multicolumn{3}{|c|}{ SE } & \multicolumn{3}{|c|}{ SW } & \multirow{2}{*}{\multicolumn{3}{|c|}{$\stackrel{\bar{m}}{\vec{n}} \mathrm{H}$}} \\
\hline $\begin{array}{c}\text { Common } \\
\text { name }\end{array}$ & $\begin{array}{l}\text { Latin } \\
\text { name }\end{array}$ & \# & $\frac{\pi}{n}$ & $\mathrm{H}$ & \# & $\frac{\pi}{m}$ & $\mathrm{H}$ & \# & $\stackrel{m}{\bar{n}}$ & $\mathrm{H}$ & & & \\
\hline \multirow{6}{*}{ 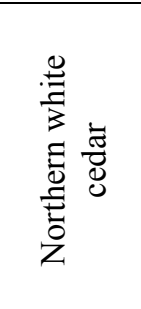 } & \multirow{6}{*}{ 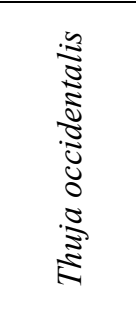 } & \multirow[t]{6}{*}{26} & 29 & 12 & \multirow[t]{6}{*}{7} & 16 & 8 & \multirow[t]{6}{*}{21} & 13 & 9 & \multirow[t]{6}{*}{39} & 16 & 11 \\
\hline & & & 32 & 13 & & 43 & 14 & & 7 & 4 & & 12 & 11 \\
\hline & & & 24 & 10 & & \multirow[t]{4}{*}{17} & \multirow[t]{4}{*}{11} & & 33 & 13 & & 27 & 12 \\
\hline & & & 16 & 8 & & & & & 38 & 14 & & 10 & 8 \\
\hline & & & & & & & & & 8 & 9 & & 5 & 4 \\
\hline & & & & & & & & & & & & 9 & 8 \\
\hline 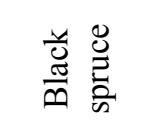 & 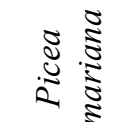 & 1 & 32 & 16 & & & & & & & 1 & 33 & 13 \\
\hline \multirow{4}{*}{ 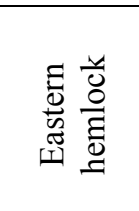 } & \multirow{4}{*}{ 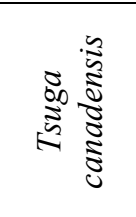 } & 1 & 32 & 15 & 4 & 19 & 13 & & & & & & \\
\hline & & & & & & 30 & 16 & & & & & & \\
\hline & & & & & & 6 & 4 & & & & & & \\
\hline & & & & & & 11 & 9 & & & & & & \\
\hline \multirow{3}{*}{ 를 } & \multirow{3}{*}{ 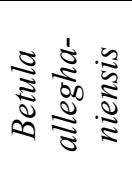 } & 1 & 27 & 14 & 3 & 38 & 16 & \multirow[t]{3}{*}{2} & 25 & 13 & & & \\
\hline & & & & & & 23 & 14 & & 33 & 14 & & & \\
\hline & & & & & & 9 & 10 & & & & & & \\
\hline \multirow{2}{*}{ 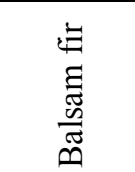 } & \multirow{2}{*}{ 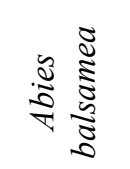 } & & & & 1 & 18 & 14 & 2 & 17 & 12 & 2 & & 13 \\
\hline & & & & & & & & & 24 & 14 & & 16 & 15 \\
\hline \multirow{3}{*}{ 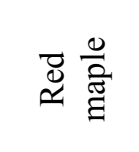 } & \multirow{3}{*}{ 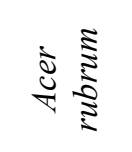 } & & & & 3 & 18 & 13 & 1 & 30 & 14 & & & \\
\hline & & & & & & 27 & 20 & & & & & & \\
\hline & & & & & & 24 & 16 & & & & & & \\
\hline
\end{tabular}

